\title{
ESTABELECIMENTO DA VIDA ÚTIL DE HORTALIÇAS \\ MINIMAMENTE PROCESSADAS SOB ATMOSFERA \\ MODIFICADA E REFRIGERAÇÃO
}

\section{LUCIMEIRE PILON}

\begin{abstract}
Dissertação apresentada à Escola Superior de Agricultura "Luiz de Queiroz", Universidade de São Paulo, para obtenção do título de Mestre em Ciências, Área de Concentração: Ciência e Tecnologia de Alimentos.
\end{abstract}

P I R A C I C A B A

Estado de São Paulo - Brasil

Julho - 2003 


\section{ESTABELECIMENTO DA VIDA ÚTIL DE HORTALIÇAS \\ MINIMAMENTE PROCESSADAS SOB ATMOSFERA \\ MODIFICADA E REFRIGERAÇÃO}

\section{LUCIMEIRE PILON}

Engenheiro Agrônomo

Orientadora: Prof ${ }^{\text {a }}$. Dr. ${ }^{\text {a }}$ MARÍLIA OETTERER

Dissertação apresentada à Escola Superior de Agricultura "Luiz de Queiroz", Universidade de São Paulo, para obtenção do título de Mestre em Ciências, Área de Concentração: Ciência e Tecnologia de Alimentos.

P I R A C I C A B A

Estado de São Paulo - Brasil

Julho - 2003 


\title{
Dados Internacionais de Catalogação na Publicação (CIP) \\ DIVISÃO DE BIBLIOTECA E DOCUMÉNTAÇÃO - ESALQ/USP
}

\author{
Pilon, Lucimeire \\ Estabelecimento da vida útil de hortaliças minimamente processadas sob \\ atmosfera modificada e refrigeração / Lucimeire Pilon. - - Piracicaba, 2003. \\ $111 \mathrm{p}$. \\ Dissertação (mestrado) - - Escola Superior de Agricultura Luiz de Queiroz, \\ 2003. \\ Bibliografia.
}

1. Armazenamento em atmosfera modificada 2. Beta-caroteno 3. Embalagem de alimento 4. Hortaliças 5. Refrigeração 6. Vácuo 7. Vitamina CI. Título

CDD 664.8 
De dico esta dissertaçãa,

À minha mãe, Marli e à minha avó, Iolanda,

pelo constante incentivo, pe lo amore

por estarem ao meu lado, sempre,

a minha eterna gratidão!

Aos meus irmãos, Eldinho, Cristiane e Rafael,

pela paciência, incentivo e carinfo. 


\title{
AGRADECIMENTOS
}

\author{
À minfa orientadora Dra. Marilia Oetterer, pelo exemplo de \\ profissionalismo, incentivo, amizade e dedicação durante a realização desta \\ pesquisa;
}

À Escola Superior de Agricultura "Luiz de Queiroz", Universidade de São Paulo, e Departamento de Agroindústria, Alimentos e $\mathcal{N u t r i c ̧ a ̃ o ~ p e l a ~ o p o r t u n i d a d e ~}$ de realização da pesquisa;

À Fundação de Apoio à pesquisa do Estado de S ão Paulo (FAPES P) pela bolsa de mestrado e financiamento da pesquisa;

À Empresa Da Roça, pelas embalagens cedidas, imprescindíveis para a realização dos experimentos;

Ao Prof. Dr. Cláudio Ros a Gallo pe la colaboração e auxílio na e laboração das análises microbiológicas;

À Prof ${ }^{a}$ Dra. Marta Helena Fillet S poto pela colaboração, amizade e auxílio na e lab or ação da análise sensorial;

Ao Prof. Dr. Ernani Porto pelas inúmeras sugestões, incentivo e amizade; 
Ao Prof. Dr. Décio Barbin do Departamento de Ciências Exatas, pelo auxílio na re alização das análises estatís tic as;

Ao Prof. Dr. Francisco Antonio Monteiro do Departamento de Solos e $\mathcal{N}$ utrição de Plantas, pelas sugestões, comentários e amizade;

Aos funcionários do Departamento de Agroindústria, Alime ntos e Nutrição, especialmente às tecnicas do Laboratório de Processamento de Alimentos, Ivani Marchetto Moreno, Roberta Rizzo Benato e I uliana Antunes Galvão;

Às Gibliotecárias Midiam Gustinelli e Beatriz Helena Giongo pelo auxílio bíbliográfico prestado;

Aos estagiários e amigos Maria Chantal $\mathcal{T}$ etelboim e Alexandre Freire, pelo ime nso auxílio na realização do experimento;

Ao Eduardo O live ir a S alán pe lo carinho, participação, imensa colaboração e incentivo de monstrados;

Aos meus amigos de mestrado, Roberta, Tatiana, Aelson, Marielen, Selma, responsáve is pelos bons momentos.

Àtodos os participantes da análise sensorial;

$\mathcal{E}$ a todos que contribuiram direta e indiretamente para a execução desta pesquisa; 


\section{SUMÁRIO}

Página

LISTA DE FIGURAS .................................................................................. viii

LISTA DE TABELAS ................................................................................. $\mathrm{x}$

RESUMO …...........................................................................................

SUMMARY ................................................................................................. XV

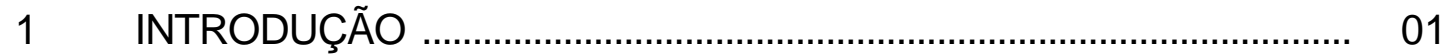

2 REVISÃO DE LITERATURA ........................................................... 06

2.1 Considerações gerais sobre o processamento mínimo ....................... 06

2.2 Consumo de hortaliças .......................................................................... 08

2.3 Utilização na dieta e estabilidade das vitaminas e minerais ............... 09

$2.4 \quad$ Efeitos do processamento no valor nutritivo ......................................... 15

2.5 Microbiologia dos vegetais minimamente processados ...................... 16

2.6 Contaminação microbiana de vegetais ................................................ 19

2.7 Outros patógenos de ocorrência em vegetais .................................... 21

2.8 Sanificação de vegetais ................................................................ 21

2.8.1 Cloro ................................................................................................ 22

2.8.2 Ácidos orgânicos ............................................................................. 24

$2.9 \quad$ Efeito dos gases nos vegetais ......................................................... 25

2.10 Embalagens para hortaliças ............................................................... 27

2.11 Embalagem com Atmosfera modificada ............................................. 29

2.11.1 Controle dos microrganismos em atmosfera modificada ................... 31

2.11.2 Atmosfera modificada e nutrientes ...................................................... 34

3 MATERIAL E MÉTODOS ............................................................ 36 
$3.1 \quad$ Matérias-primas ........................................................................... 36

3.2 Processamento da cenoura .............................................................. 36

3.3 Processamento do pimentão ............................................................. 38

3.4 Processamento da salada mista (vagem e batata) ............................. 39

3.5 Delineamento experimental .............................................................. 41

3.6 Análises físico-químicas ..................................................................... 41

3.7 Análises microbiológicas ............................................................... 43

3.8 Análise sensorial .................................................................................. 44

4 RESULTADOS E DISCUSSÃO ……………………......................... 46

$4.1 \quad$ Análises físico-químicas ................................................................... 46

4.1.1 Composição centesimal ................................................................... 46

4.1.2 Acidez titulável .............................................................................. 55

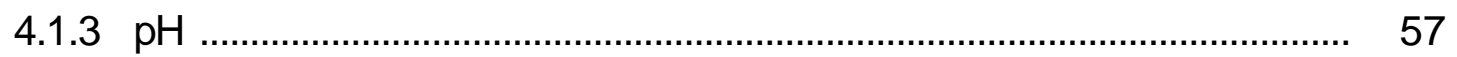

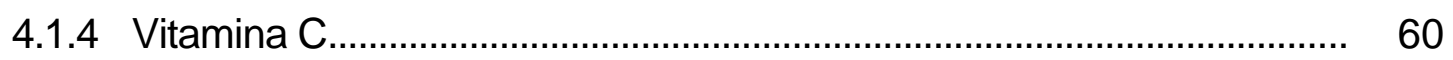

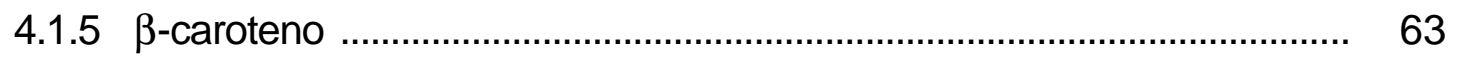

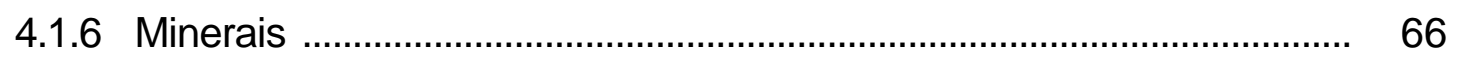

4.2 Análises microbiológicas ..................................................................... $\quad 70$

$4.3 \quad$ Análise sensorial ............................................................................. 73

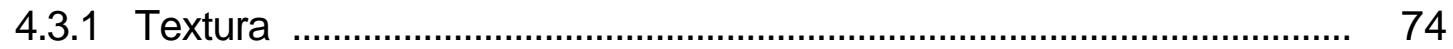

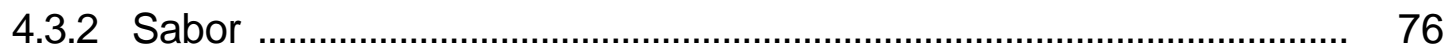

4.3.3 Aroma e avaliação global.................................................................... 77

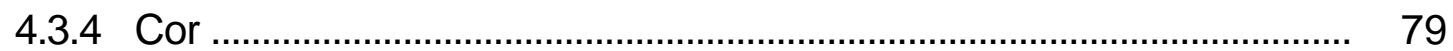

5 CONCLUSÕES ............................................................................. 82

REFERÊNCIAS BIBLIOGRÁFICAS .................................................... 84

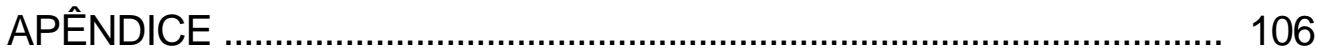




\section{LISTA DE FIGURAS}

Página

1 Fluxograma de obtenção da cenoura minimamente processada

2 Fluxograma de obtenção do pimentão minimamente processado

3 Fluxograma de obtenção da salada mista minimamente processada

4 Umidade em cenouras, pimentões e salada mista minimamente processados, embalados sob ar atmosférico, vácuo e atmosfera modificada, armazenados sob refrigeração a $1^{\circ} \mathrm{C} \pm 1^{\circ} \mathrm{C}$

5 Lipídeos em cenouras, pimentões e salada mista minimamente processados, embalados sob ar atmosférico, vácuo e atmosfera modificada, armazenados sob refrigeração a $1^{\circ} \mathrm{C} \pm 1^{\circ} \mathrm{C}$.

6 Proteína em cenouras, pimentões e salada mista minimamente processados, embalados sob ar atmosférico, vácuo e atmosfera modificada, armazenados sob refrigeração a $1^{\circ} \mathrm{C} \pm 1^{\circ} \mathrm{C}$

7 Cinza em cenouras, pimentões e salada mista minimamente processados, embalados sob ar atmosférico, vácuo e atmosfera modificada, armazenados sob refrigeração a $1^{\circ} \mathrm{C} \pm 1^{\circ} \mathrm{C}$

8 Acidez titulável em cenouras, pimentões e salada mista minimamente processados, embalados sob ar atmosférico, vácuo e atmosfera modificada, armazenados sob refrigeração a $1^{\circ} \mathrm{C} \pm 1^{\circ} \mathrm{C}$.

$9 \mathrm{pH}$ em cenouras, pimentões e salada mista minimamente processados, embalados sob ar atmosférico, vácuo e atmosfera modificada, armazenados sob refrigeração a $1^{\circ} \mathrm{C} \pm 1^{\circ} \mathrm{C}$ 
10 Vitamina C em cenouras e pimentões minimamente processados, embalados sob ar atmosférico, vácuo e atmosfera modificada,

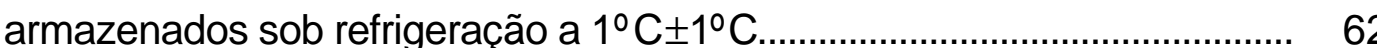

$11 \beta$-caroteno em cenouras, pimentões e salada mista minimamente processados, embalados sob ar atmosférico, vácuo e atmosfera modificada, armazenados sob refrigeração a $1^{\circ} \mathrm{C} \pm 1^{\circ} \mathrm{C}$

12 Psicrotróficos em cenouras, pimentões e salada mista minimamente processados, embalados sob ar atmosférico, vácuo e atmosfera modificada, armazenados sob refrigeração a $1^{\circ} \mathrm{C} \pm 1^{\circ} \mathrm{C}$ 


\section{LISTA DE TABELAS}

Página

1 Teores das vitaminas $\mathrm{A}$ e $\mathrm{C}$ em hortaliças

2 Teores de minerais em hortaliças

3 Umidade em cenoura, pimentão e salada mista minimamente processados, embalados sob ar atmosférico, vácuo e atmosfera modificada, armazena do sob refrigeração a $1^{\circ} \mathrm{C} \pm 1^{\circ} \mathrm{C}$.

4 Lipídeos em cenoura, pimentão e salada mista minimamente processados, embalados sob ar atmosférico, vácuo e atmosfera modificada, armazenadas sob refrigeração a $1^{\circ} \mathrm{C} \pm 1^{\circ} \mathrm{C}$.

5 Proteína em cenoura, pimentão e salada mista minimamente processados, embalados sob ar atmosférico, vácuo e atmosfera modificada, armazenadas sob refrigeração a $1^{\circ} \mathrm{C} \pm 1^{\circ} \mathrm{C}$.

6 Cinza em cenoura, pimentão e salada mista minimamente processados, embalados sob ar atmosférico, vácuo e atmosfera modificada, armazenadas sob refrigeração a $1^{\circ} \mathrm{C} \pm 1^{\circ} \mathrm{C}$

7 Acidez titulável em cenoura, pimentão e salada mista minimamente processados, embalados sob ar atmosférico, vácuo e atmosfera modificada, armazenadas sob refrigeração a $1^{\circ} \mathrm{C} \pm 1^{\circ} \mathrm{C}$.

$8 \mathrm{pH}$ em cenoura, pimentão e salada mista minimamente processados, embalados sob ar atmosférico, vácuo e atmosfera modificada, armazenadas sob refrigeração a $1^{\circ} \mathrm{C} \pm 1^{\circ} \mathrm{C}$ 
9 Vitamina C em cenoura, pimentão e salada mista minimamente processados, embalados sob ar atmosférico, vácuo e atmosfera modificada, armazenadas sob refrigeração a $1^{\circ} \mathrm{C} \pm 1^{\circ} \mathrm{C}$.

$10 \beta$-caroteno em cenoura, pimentão e salada mista minimamente processados, embalados sob ar atmosférico, vácuo e atmosfera modificada, armazenadas sob refrigeração a $1^{\circ} \mathrm{C} \pm 1^{\circ} \mathrm{C}$

11 Minerais em cenoura minimamente processada, embalada sob ar atmosférico, vácuo e atmosfera modificada, armazenada sob refrigeração a $1^{\circ} \mathrm{C} \pm 1^{\circ} \mathrm{C}$.

12 Minerais em pimentão minimamente processado, embalado sob ar atmosférico, vácuo e atmosfera modificada, armazenado sob refrigeração a $1^{\circ} \mathrm{C}+1^{\circ} \mathrm{C}$

13 Minerais em salada mista minimamente processada, embalada sob ar atmosférico, vácuo e atmosfera modificada, armazenada sob refrigeração a $1^{\circ} \mathrm{C} \pm 1^{\circ} \mathrm{C}$

14 Coliformes totais e anaeróbios mesófilos em pimentões minimamente processados, armazenados a $1^{\circ} \mathrm{C} \pm 1^{\circ} \mathrm{C}$.

15 Textura em cenoura, pimentão e salada mista minimamente processados, embalados sob ar atmosférico, vácuo e atmosfera modificada, armazenados sob refrigeração a $1^{\circ} \mathrm{C} \pm 1^{\circ} \mathrm{C}$

16 Sabor em cenoura, pimentão e salada mista minimamente processados, embalados sob ar atmosférico, vácuo e atmosfera modificada, armazenados sob refrigeração a $1^{\circ} \mathrm{C} \pm 1^{\circ} \mathrm{C}$

17 Aroma em cenoura, pimentão e salada mista minimamente processados, embalados sob ar atmosférico, vácuo e atmosfera modificada, armazenados sob refrigeração a $1^{\circ} \mathrm{C} \pm 1^{\circ} \mathrm{C}$.

18 Avaliação global de cenoura, pimentão e salada mista minimamente processados, embalados sob ar atmosférico, vácuo e atmosfera modificada, armazenados sob refrigeração a $1^{\circ} \mathrm{C} \pm 1^{\circ} \mathrm{C}$ 
19 Cor de cenoura, pimentão e salada mista minimamente processados, embalados sob ar atmosférico, vácuo e atmosfera modificada,

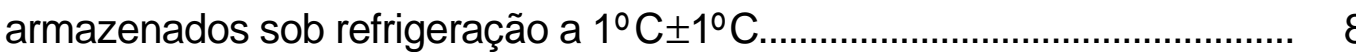




\title{
ESTABELECIMENTO DA VIDA ÚTIL DE HORTALIÇAS MINIMAMENTE PROCESSADAS SOB ATMOSFERA MODIFICADA E REFRIGERAÇÃO
}

\author{
Autora: LUCIMEIRE PILON \\ Orientadora: Prof ${ }^{\text {a }}$. Dr ${ }^{\mathrm{a}}$. MARÍLIA OETTERER
}

\section{RESUMO}

As perdas pós-colheita de alimentos hortícolas justificam a adoção de técnicas de conservação. Uma vez beneficiados, esses produtos permitem agregar valor à produção primária e se tornam de conveniência ao consumidor. Essa pesquisa teve como objetivo definir as metodologias do processamento mínimo de cenoura, pimentão e salada mista (batata e vagem), quanto ao tipo e intensidade de adoção das técnicas de barreiras e monitorar o processamento, via controle microbiológico, sensorial, físico-químico e nutricional. As hortaliças foram lavadas em água corrente, descascadas e cortadas com facas afiadas de aço inoxidável. Para a sanificação, foram imersas por $15 \mathrm{~min}$ em água refrigerada $\left(\neq 7^{\circ} \mathrm{C}\right)$ com $100 \mathrm{mg} \mathrm{L}-1$ de cloro livre a pH ajustado para 7,0; a seguir foram centrifugadas a $550-900 \mathrm{G}$, por $5 \mathrm{~min}$. As hortaliças foram acondicionadas, manualmente, em sacos plásticos de filme multicamada laminado, do tipo BOPP/PEBD (polipropileno biorientado/polietileno de baixa 
densidade). As embalagens foram fechadas em seladora modelo AP-500, marca Tec Maq, sob ar atmosférico, vácuo e atmosfera modificada ( $2 \%$ de $\mathrm{O}_{2}$, $10 \% \mathrm{CO}_{2}$ e $88 \%$ de $\mathrm{N}_{2}$ ) e a seguir foram armazenados sob refrigeração a $1^{\circ} \mathrm{C} \pm$ 1ํ․ A vitamina $C$ não foi afetada em nenhum dos tratamentos nos três produtos. Os teores de $\beta$-caroteno mantiveram-se praticamente constantes em cenoura e salada mista; no pimentão, após a primeira semana de armazenamento, sofreram um decréscimo, permanecendo praticamente inalterados ao longo do armazenamento. Quanto à análise sensorial, os resultados para a cenoura e salada mista, foram satisfatórios até 21 dias de armazenamento para todos os tratamentos; exceto para o pimentão. Os três produtos obtiveram em todos os tratamentos, contagens para psicrotróficos variando de $10^{2}$ a $10^{5} \mathrm{UFC} / \mathrm{g}, 10^{1}$ a $10^{3} \mathrm{UFC} / \mathrm{g}$ e $10^{3}$ a $10^{6} \mathrm{UFC} / \mathrm{g}$, respectivamente. Anaeróbios mesófilos e coliformes totais, foram constatados em pimentões minimamente processados. Porém, as baixas contagens obtidas, em todos os tratamentos, mostraram que a vida útil destes prolongou-se até o $14^{\circ}$ dia de armazenamento. Para a cenoura e salada mista minimamente processadas, não foram constatados coliformes totais e fecais, anaeróbios mesófilos e Salmonella em nenhum dos tratamentos. 


\title{
ESTABLISHING THE SHELF LIFE OF MINIMALLY PROCESSED VEGETABLES BY MODIFIED ATMOSPHERE AND REFRIGERATION
}

\author{
Author: LUCIMEIRE PILON \\ Adviser: Prof ${ }^{a}$. Drª . MARÍLIA OETTERER
}

\section{SUMMARY}

The postharvest losses of horticultural products justify the adoption of preservation techniques. Once these products are processed, they add value to the primary products and they become convenient to the consumer. This research had the purpose of defining the methodologies for minimal processing of carrot, green pepper and mixed salad of potato and string bean in relation to the type and intensity of adoption of the barrier techniques. In addition, it was our objective to monitor the processing, through by microbiological, sensory, physical-chemical and nutritional evaluation. The vegetables were washed in running water, peeled and cut with sharp stainless steel knives. For the sanitization they were submerged, for $15 \mathrm{~min}$, in cold water $\left( \pm 7^{\circ} \mathrm{C}\right)$ with $100 \mathrm{mg} \mathrm{L}^{-1}$ of free chlorine at $\mathrm{pH} 7,0$; next, they were centrifuged at $550-900 \mathrm{G}$, for $5 \mathrm{~min}$. The product was hand packed in plastic bags BOPP/LDPE (biorientated polypropylene/low-density polyethylene). The packages were sealed under air, vacuum and modified atmosphere $\left(2 \% \mathrm{O}_{2}, 10 \% \mathrm{CO}_{2}\right.$ and $88 \%$ 
$\mathrm{N}_{2}$ ) and stored under refrigeration at $1^{\circ} \mathrm{C} \pm 1^{\circ} \mathrm{C}$. The vitamin $\mathrm{C}$ content was not affected in any of the treatments. The values for $\beta$-carotene remained stable for carrot and mixed salad. For the green pepper, the values decreased after the first week of sorage. In relation to the sensory analysis, carrot and mixed salad were considered satisfactory until 21 days of storage for all treatments; but for green pepper. In all treatments, counts for the three products ranged psychrotrophic ranging from $10^{2}$ to $10^{5} \mathrm{UFC} \mathrm{g}^{-1}, 10^{1}$ to $10^{3} \mathrm{UFC}^{-1}, 10^{3}$ to $10^{6}$ UFC $g^{-1}$, respectively. Anaerobic mesophiles and total coliforms were observed in minimally processed green peppers. However, the low count obtained in all treatments indicated a shelf life of 14 days. For the minimally processed carrot and mixed salad, no total or fecal coliforms, anaerobic mesophiles and Salmonella were observed in any of the treatments. 


\section{INTRODUÇÃO}

Os hábitos de se produzir e consumir hortaliças no Brasil foram introduzidos pelos portugueses na época da colonização e foram intensificados, posteriormente, pela corrente imigratória de europeus e asiáticos, principalmente espanhóis, italianos, alemães, poloneses e japoneses que se instalaram, preferencialmente, nos estados das regiões Sudeste e Sul como Rio de Janeiro, São Paulo, Paraná, Santa Catarina e Rio Grande do Sul (Makishima, 2000).

Segundo dados da Associação Brasileira de Indústria de Alimentos (ABIA), discutidos por Melo (2001), o Estado de São Paulo tem cerca de 40\% de seu Produto Interno Bruto (PIB) relacionado ao agronegócio. Cerca de 1 milhão de pessoas trabalham na zona rural e 3 milhões estão envolvidas na cadeia do agronegócio, um setor formado por 277.124 propriedades rurais, sendo $62 \%$ com até 100 ha, exploradas por pequenos e médios produtores. Esses números mostram o potencial da agricultura não só em São Paulo, como no País.

A indústria nacional de alimentos, que produz 930 mil empregos diretos, faturou US\$ 54,7 bilhões no ano de 2000; as frutas e vegetais processados representaram US $\$ 3,8$ bilhões (Melo, 2001).

O Brasil é um país que importa mais do que exporta hortaliças frescas e/ou processadas. Em 1999 exportou 110 mil t no valor de US\$ 178 milhões e importou 471 mil t correspondentes a US\$ 222 milhões (Makishima, 2000).

No Brasil, embora haja grande disponibilidade de produtos hortícolas acessíveis a substancial parcela da população, ocorrem perdas significativas 
dos mesmos no campo e na fase pós-colheita, pela produção desorganizada e carência de uso de tecnologias adequadas no cultivo, manuseio, armazenamento e conservação. Em 1992, estimou-se a perda em US\$ 530 milhões para hortaliças, e em US\$ 509 milhões para frutos (Honório, 1993). Segundo Raydon (1993), um dos fatores que mais favorece o desperdício é o excesso de produção que no caso de hortifrutigranjeiros, ocorre para aqueles produtos não passíveis de processamento.

Nos últimos anos, porém, tem havido maior conscientização de produtores e distribuidores sobre a necessidade de suporte tecnológico, visando o melhor aproveitamento de vegetais que não alcançam padrão para comercialização (Melo, 2001).

Uma tecnologia alternativa utilizada para redução das perdas e melhor utilização da colheita é o processamento mínimo de frutas e hortaliças. As perspectivas são promissoras para estes produtos que têm como público alvo os serviços de fornecimento de alimentos prontos e de preparo rápido (Chitarra, 1999).

Nos Estados Unidos, de acordo com o Produce Marketing Association, as vendas de vegetais minimamente processados alcançaram US $\$ 7,9$ bilhões em 1997, prevendo-se um crescimento para US\$ 19 bilhões até 2003. Estimase que estes produtos já representem $10 \%$ de todas as vendas de frutas e hortaliças. Entre as hortaliças minimamente processadas, as baby carrots são os itens mais vendidos, seguidos por brócolis e couve-flor. As saladas mistas pré-embaladas já respondem por vendas de $U \$ 1,5$ bilhão/ano, mostrando índices de crescimento de $28 \%$ nos últimos anos. As vendas diretamente ao varejo representam $40 \%$ das vendas totais no segmento, sendo que as hortaliças representam $75 \%$ da oferta e as frutas, $25 \%$ (Junqueira \& Luengo, 1999).

O agronegócio brasileiro está deixando de ser um investimento para poucos e se tornando, também, uma possibilidade de renda para o pequeno proprietário que, por sua vez, deve investir em qualidade e em produto 
diferenciado. A produção de alimentos minimamente processados é um segmento em expansão nas pequenas propriedades, exemplo de produção diferenciada e com grande mercado consumidor (Mesquita, 2001).

$\mathrm{O}$ aumento da demanda por vegetais minimamente processados tem levado a um aumento na qualidade e diversidade dos produtos disponíveis para o consumidor no mercado. Tecnologias de preservação, principalmente a refrigeração e a atmosfera modificada estão sendo confiadas a assegurar a qualidade desses produtos. Revisões feitas por Zagory \& Kader (1988); Carlin et al. (1990); Izumi et al. (1996); Gil et al. (2002) e Jayas \& Jeyamkondan (2002) demonstraram a importância do uso da atmosfera modificada, composta da mistura pré-estabelecida dos gases, $\mathrm{O}_{2}, \mathrm{CO}_{2}$ e N , na manutenção da qualidade e aumento da vida útil de vegetais minimamente processados.

Acredita-se que o efeito inibitório do $\mathrm{CO}_{2}$ resulte principalmente da difusão do $\mathrm{H}_{2} \mathrm{CO}_{3}$ através da membrana bacteriana, causando alterações no $\mathrm{pH}$ intracelular, assim como mudanças enzimáticas no metabolismo celular (Bennik et al., 1998).

As condições de armazenamento são aspectos importantes que podem afetar, tanto a população final como os tipos de microrganismos que crescem em produtos in natura. A temperatura, a concentração de gases e a umidade relativa na embalagem são os fatores de maior influência sobre a microbiota e a determinação da vida útil do produto (Rosa, 2002).

As temperaturas entre $0^{\circ} \mathrm{C}$ e $3^{\circ} \mathrm{C}$ podem ampliar a vida útil dos vegetais minimamente processados entre 5 e 18 dias, pois a degradação da qualidade é retardada pelo decréscimo da temperatura, ocasionando uma redução na taxa respiratória (Scott, 1989). Conseqüentemente, as perdas sensoriais podem ser reduzidas, particularmente as provenientes de reações oxidativas nos pigmentos e lipídeos, bem como, haverá redução da velocidade das oxidações bioquímicas durante a senescência (Scott, 1989; Watada et al., 1990; Wiley, 1994). 
O sistema de embalagem, segundo Manzano et al. (1995), tem influência fundamental na atividade metabólica dos produtos vegetais. O nível de gás nas embalagens sob atmosfera modificada, geralmente se dá em função da permeabilidade do filme escolhido e do comportamento respiratório do produto.

As tabelas de composição dos alimentos disponíveis aos pesquisadores e consumidores, como as tabelas do Estudo Nacional de Despesas Familiares ENDEF (1977), Franco (1999) e USP (2001), trazem as informações dos nutrientes em hortaliças in natura, embora saiba-se que tanto a distribuição quanto o preparo doméstico, colaboram para a perda tanto da vitamina $\mathrm{C}$, quanto do $\beta$-caroteno.

O efeito do processamento mínimo sobre a manutenção da qualidade nutricional ainda não foi claramente estabelecido. Tem-se, portanto necessidade de informações sobre os efeitos do processamento mínimo, tipos de embalagens e armazenamento sobre os teores de nutrientes nesses vegetais (Hussein et al., 2000).

Os vegetais minimamente processados têm ocupado um espaço significativo nas gôndolas dos principais supermercados brasileiros. Assim, na cidade de Piracicaba, SP, é possível adquirir estes produtos, por exemplo, na rede de supermercados Pão de Açúcar. As marcas predominantes àvenda em junho de 2003 são as seguintes: Fresh \& Freeze, Hydro Salads, Greenleaves, Master Salads, Mister Rabbit e Fonte da vida. Os produtos são: Alface americana, escarola, acelga fatiada, cenoura ralada, salada mista composta de cenoura, vagem, chuchu, abobrinha e couve-flor, beterraba ralada, couve-flor, entre outros, embalados em sacos plásticos, atmosfera modificada, vácuo e bandejas plásticas e de isopor.

Estes produtos apresentam vida útil de 6 a 7 dias e devem estar refrigerados a $10^{\circ} \mathrm{C}$. A rotulagem nutricional segue os padrões da legislação brasileira e apresentam os teores de valor calórico, carboidratos, proteína, gorduras totais, gorduras saturadas, colesterol, fibra alimentar, cálcio, ferro e sódio (Agência Nacional de Vigilância Sanitária - ANVISA, 2002). A marca 
Greenleaves traz informações sobre as vitaminas A, B e C, além dos outros nutrientes. Também é apresentado no rótulo o valor correspondente a uma porção e que preencham percentuais das recomendações diárias. O valor agregado é alto; por exemplo, $250 \mathrm{~g}$ de cenoura minimamente processada custa $R \$ 2,35$, a cenoura in natura é vendida a $R \$ 0,99$ o quilo.

Os produtos desta pesquisa são preconizados para uma vida útil de 21 dias submetidos àrefrigeração de $1^{\circ} \mathrm{C} \pm 1^{\circ} \mathrm{C}$ e na rotulagem podem apresentar $\mathrm{O}$ valor de retenção de vitamina $\mathrm{C}$ e b-caroteno. O monitoramento microbiológico permite sinalizar a rastreabilidade dos produtos desenvolvidos sob as normas das boas práticas de fabricação após a colheita.

Essa pesquisa teve como objetivo, definir as metodologias do processamento mínimo de œnoura, pimentão e salada mista (batata e vagem), quanto a adoção das técnicas de barreiras e monitorar o processamento, via controle microbiológico, sensorial, físico-químico e nutricional. 


\section{REVISÃO DE LITERATURA}

\subsection{Considerações gerais sobre o processamento mínimo}

O termo "frutas e hortaliças minimamente processadas" define os produtos que contém tecidos vivos, ou aqueles que sofreram leve modificação em suas condições iniciais, aparentando frescor e mantendo sua qualidade. Estes tecidos não apresentam as mesmas respostas fisiológicas que o produto não tratado e inteiro, com diferentes respostas ao meio ambiente e ⿱宀 condições de embalagem (Wiley, 1994). São produtos in natura prontos para o consumo ou uso no preparo de outros pratos (Nguyen-The \& Carlin, 1994). Também conhecidos como levemente processados, parcialmente processados, processados frescos, cortados frescos ou pré-preparados (Chitarra, 1998).

O processamento mínimo de frutas e hortaliças tem como principal vantagem 0 fato de produtores rurais poderem entregar seus produtos diretamente às redes de supermercados, restaurantes, hotéis e lanchonetes, evitando intermediários e Centrais de Abastecimento.

O consumo de hortaliças cresceu $20 \%$ na última década, segundo dados da Associação Brasileira de Supermercados e os pedidos para aquisição de hortaliças minimamente processadas, somente quando se considera a rede Carrefour, aumentaram em 50\% em um ano (Rabello, 1999).

A vida útil desses vegetais preconizada pelas empresas é de 5 a 7 dias; nos Estados Unidos, a vida útil varia de 14 dias até 21 dias. Os processadores têm acesso ao que há de mais moderno em sistemas de atmosfera modificada e automação industrial. O problema está no campo, pois os produtores são 
pouco tecnificados e nem sempre podem adquirir sistemas avançados para produção de hortaliças. A comercialização fica só no CEASA (Centrais de Abastecimento e Serviços Auxiliares), como ocorre nos municípios paulistas de Ibiúna e Piedade; os produtores vendem para os intermediários e nunca sabem por quanto venderam e nem quanto vão receber (Ferreira, 2000).

De acordo com Chitarra (1998), os produtos minimamente processados são mais sensíveis à deterioração que os produtos naturais, porque perdem o tecido protetor (casca) que promove o efeito de barreira física contra a invasão microbiana; o corte dos tecidos libera nutrientes que servem de alimento aos microrganismos, acelerando o desenvolvimento destes; o manuseio excessivo também torna o produto mais suscetível àinvasão microbiana.

Práticas higiênicas eficientes são necessárias em cada etapa da cadeia alimentar, desde a produção até o consumo dos alimentos. Cada passo pode influenciar a qualidade dos alimentos eventualmente consumidos. Quantos aos aspectos relativos à segurança alimentar vale ressaltar que do ponto de vista qualitativo o maior controle higiênico está na implantação de medidas como as Boas Práticas de Fabricação (BPF) e a Análise de Perigos e Pontos Críticos de Controle - APPCC (APPCC, 1997).

A segurança é o atributo de qualidade mais desejável. Assim, os produtos hortícolas devem ser isentos de toda e qualquer substância química que possa causar danos àsaúde do consumidor. Os padrões de segurança são estabelecidos por leis federais ou estaduais, visando a preservação da saúde pública, com base na prevenção do desenvolvimento de microrganismos patogênicos ou prejudiciais, bem como na proteção contra a presença de substâncias tóxicas naturais ou contaminantes, que podem ser resíduos de defensivos agrícolas ou de outros produtos (Chitarra, 1998). 


\subsection{Consumo de hortaliças}

O ENDEF, realizado em meados da década de 70 , mostrou que dentre os grupos de alimentos consumidos, as hortaliças participam com apenas $1 \%$ do total calórico da dieta para a população paulista; representam, porém, 36\% do teor de vitamina $\mathrm{C}$ da dieta (IBGE, 1978).

Em estudos realizados pelo Departamento de Nutrição da Faculdade de Saúde Pública da Universidade de São Paulo citados por Silva (1990), verificour se que as hortaliças fornecem $2 \%$ do total energético e $40 \%$ do teor de vitamina $\mathrm{C}$, valores bastante semelhantes aos descritos no ENDEF.

O consumo per capita de hortaliças varia de 25 a $30 \mathrm{~kg} / \mathrm{ano}$ nas regiões Norte e Nordeste, e de 45 a 50 kg/ano nas regiões Sul, Sudeste e CentroOeste. Essas médias são bastante inferiores àquelas observadas em outros países, principalmente da Europa, Ásia e América do Norte onde o consumo per capita atinge aproximadamente 100 a $110 \mathrm{~kg} / \mathrm{ano}$. Por outro lado, tem-se notado um aumento de 6 a 10\% nas quantidades consumidas, que pode ser devido às mudanças de hábitos de vida e alimentar da população (Makishima, 2000).

Devido ao papel fundamental de hortaliças na definição do estado de saúde e na prevenção de doenças, é interessante registrar alguns dados sobre o consumo desse alimento entre a população infantil.

Estudos sobre o consumo dos alimentos, realizados em vários municípios do interior do Estado de São Paulo, citados por Mazzilli (1983) indicam o baixo consumo de hortaliças e frutas entre crianças. Wilson et al. (1980), estudando o consumo alimentar individual de crianças de 1 a 13 anos também encontraram baixa ingestão de hortaliças e frutas. Resultados divulgados pelo Instituto de Nutrição Annes Dias do Rio de Janeiro (1985), citados por Silva (1996), destacam que 52\% dos escolares, recém ingressos na rede municipal de ensino não consumiam frutas e hortaliças. Lerner (1994), 
estudando o consumo alimentar dos adolescentes, constatou baixa ingestão de hortaliças e frutas e, conseqüentemente, de ácido ascórbico.

No município de São Paulo os escolares revelaram consumir uma quantidade de hortaliças e frutas considerada insuficiente para atender æ̀ recomendações nutricionais de vitamina $A$ e outros nutrientes, conforme preconizado na Recommended Dietary Allowance- RDA (Oliveira et al., 1998).

Maestro (2002), analisando o consumo alimentar de alunos da rede pública do município de Piedade, SP, com idade entre 6 e 18 anos, verificou que a participação de frutas e hortaliças no total de alimentos consumidos, foi superado de forma substancial pelo consumo de óleos, gorduras, açúcares e doces.

Sanches (2002) relatou em estudos envolvendo escolares da rede pública de ensino do município de Piracicaba, SP, que o maior hábito de se consumir hortaliças (seis ou mais vezes por semana) foi observado em famílias de alunos que possuem mães com maior escolaridade. $O$ autor citou ainda, a preferência para o consumo de alface; já a escarola e o quiabo foram as hortaliças mais rejeitadas pelos escolares.

\subsection{Utilização na dieta e estabilidade das vitaminas e minerais}

As vitaminas são agentes essenciais ativos para manutenção das funções biológicas, podendo ocorrer em natureza como tal ou sob forma de precursores, provitaminas, que são ingeridas com os alimentos. O organismo humano pode promover a síntese de algumas vitaminas, necessitando, no entanto, do suprimento alimentar (Franco, 1999).

A vitamina $C$ é solúvel em água $(0,3 \mathrm{~g} / \mathrm{mL})$, estável na forma seca, solúvel em álcool etílico (1g/50mL), insolúvel nos solventes orgânicos, muito sensível ao oxigênio e àluz, termossensível, estável em meio ácido e instável em meio alcalino. Sua oxidação pode ser acelerada na presença de cobre ou ferro e em $\mathrm{pH}$ alcalino (Guilland \& Lequeu, 1995). É facilmente absorvida a partir do 
intestino delgado dos humanos para o sangue, por um mecanismo ativo e por difusão. A média de absorção é de 90\% (Mahan \& Arlin, 1995). Constitui importante favorecedor do potencial de aproveitamento do ferro, principalmente do ferro não-heme (Hunt et al., 1990).

A oxidação da vitamina $C$ é acelerada pela ação das enzimas (ascorbato oxidase ou peroxidase) durante o armazenamento de frutos e hortaliças. As enzimas atuam de forma intensa, quando há ruptura dos tecidos dos vegetais ou frutos, ou também quando os mesmos são mantidos sob congelamento inadequado (Cheftel \& Cheftel, 1983). O corte dos tecidos aumenta a atividade enzimática, resultando em perda rápida da vitamina $\mathrm{C}$ pelos produtos minimamente processados (Chitarra, 1999).

A vitamina $C$ é dentre as vitaminas hidrossolúveis a mais lábil e, como já referido, é facilmente oxidada por agentes químicos e físicos, perdendo sua atividade.

Quando os vegetais são preparados e conservados por $24 \mathrm{~h}$ sob refrigeração, as perdas de vitamina $\mathrm{C}$ podem ser de $45 \%$ para produtos frescos e $52 \%$ para produtos congelados. A refrigeração e o congelamento rápidos propiciam maior retenção desta vitamina (Mahan \& Arlin, 1995).

A couve, por exemplo, pode perder $1,5 \%$ de vitamina $\mathrm{C}$ por hora, aproximadamente $1 / 3$ por dia, se mantidas em condições inadequadas de temperatura e umidade. As temperaturas mais baixas diminuem a intensidade respiratória dos vegetais e a perda de umidade, prolongando assim a vida útil e preservando os nutrientes lábeis (Sgarbieri, 1987).

Segundo King \& Pablo (1987), folhas verdes conservadas àtemperaturas de $10^{\circ} \mathrm{C}$ e $21^{\circ} \mathrm{C}$ perdem $30 \%$ e $75 \%$ da vitamina $\mathrm{C}$, respectivamente, após 4 dias de estocagem. As perdas de vitamina $C$ em abóbora, chuchu, repolho e tomate variam de 22 a 56\%, segundo o modo de preparo (Silva,1990).

$A$ vitamina $A$, também conhecida pela designação de retinol, é um álcool primário, polietilênico, lipossolúvel, de grande capacidade reativa por molécula insaturada; instável devido à oxidação e à ação do calor. Sua absorção diz 
respeito à vitamina pré-formada do ácido retinóico e do $\beta$-caroteno ou outros carotenóides (Franco, 1999). O $\beta$-caroteno é encontrado principalmente na cenoura e batata doce (Hendler, 1994).

A qualidade provitamínica A de alguns carotenóides e outros efeitos potenciais benéficos à saúde, aumentam sua importância na dieta. Além disso, os carotenóides estão entre os constituintes mais apreciados dos alimentos, sendo as cores vermelha e amarela as que dão uma maior contribuição para a qualidade e atração dos alimentos (Pinheiro-Sant'Ana et al., 1996).

Pinheiro-Sant'Ana et al. (1996), estudando a estabilidade de carotenóides em cenouras (Daucus carota L.) submetidas à desidratação e métodos como cocção a vapor, cocção em água com pressão e sem pressão e cocção úmida/seca, observaram perdas de 14,36 a 39,87\% desse componente.

A utilização dos nutrientes energéticos pelo organismo é comprometida se houver deficiência de vitaminas e de minerais. De modo geral, os minerais regulam o metabolismo de diversas enzimas, mantém o equilíbrio ácido-básico e a pressão osmótica, facilitam a transferência de compostos essenciais através das membranas e, em alguns casos, fazem parte dos elementos constituintes dos tecidos dos organismos (Ferreira \& Gomes, 1996).

Os macronutrientes minerais, assim definidos por sua abundância percentual no corpo humano, compreendem o cálcio (1,5 a 2,2\%), fósforo $(0,8$ a $1,2 \%)$, potássio $(0,35 \%)$, enxofre $(0,25 \%)$, sódio $(0,15 \%)$, cloro $(0,15 \%)$ e magnésio $(0,05 \%)$. Também podem ser definidos como macrominerais todos os minerais que existem no organismo em proporção superior a 0,05\% (Dutra-de Oliveira \& Marchini, 1998).

O fósforo é amplamente distribuído na natureza sendo encontrado em todas as células. Isso significa que todos os alimentos, tanto de origem vegetal quanto animal, podem ser considerados boas fontes de fósforo (Dutra-de Oliveira \& Marchini, 1998).

O cálcio está significativamente presente em um pequeno número de alimentos, sendo os mais importantes o leite e seus derivados (Hendler, 1994). 
Outros produtos que contém cálcio são farinha de peixe, amêndoa e semente de gergelim. Entre os alimentos, o leite e derivados contribuem com $75 \%$ na oferta de cálcio; carnes e ovos, $7 \%$; vegetais, $6 \%$; e outras fontes, $12 \%$, como por exemplo, ingestão sob a forma de medicamentos (Dutra-de Oliveira \& Marchini, 1998).

Considerando que o magnésio está presente na clorofila e, portanto, em todas as plantas verdes, raramente é encontrada deficiência primária desse mineral. Dentre os alimentos ricos em magnésio estão as carnes, frutos do mar, castanhas, cereais, hortaliças e produtos lácteos (Hendler, 1994; Dutra-de Oliveira \& Marchini, 1998).

As maiores fontes naturais de potássio são as frutas e hortaliças frescas (Hendler, 1994).

Os microminerais, também denominados "elementos-traço", são minerais necessários em pequenas quantidades diárias para manutenção da normalidade metabólica e funcionamento adequado das células. Além de componente estrutural, eles exercem funções específicas no organismo, incluindo ação hormonal, atuando como co-fator enzimático ou estabilizador de reações químicas, entre elas a neutralização de radicais livres (Cunha \& Cunha, 1998).

De forma geral, os vegetais são ricos em ferro, embora a presença de outros compostos, como fibras alimentares, fitatos e oxalatos, o tornem menos disponível (Cunha \& Cunha, 1998). O ferro não heme está presente em cereais, frutas, hortaliças e produtos lácteos, que constituem os principais aportes de ferro em países em desenvolvimento, sendo com freqüência as únicas fontes (FAO, 1991).

Dentre as fontes de zinco na alimentação, encontram-se produtos integrais, levedo de cerveja, farelo e germe de trigo; os frutos do mar e as carnes são, geralmente, melhores fontes de zinco biodisponível que os vegetais (Hendler, 1994). A interação do zinco com outros nutrientes da alimentação pode aumentar ou diminuir sua absorção (Cunha \& Cunha, 1998). 
Uma alimentação variada geralmente contém cobre em quantidade suficiente para a maioria dos indivíduos saudáveis. Fontes ricas em cobre incluem o fígado animal, frutos do mar, castanhas e nozes (Hendler, 1994). Carnes, frango, peixe, ovos e cereais processados também são fontes. A quantidade de cobre em frutas e vegetais verdes depende do cultivar, concentração de cobre no solo e condições de cultivo (Cunha \& Cunha, 1998).

As melhores fontes de manganês na alimentação são grãos integrais e nozes. As frutas e vegetais verdes contêm quantidades moderadas e, como o cobre, dependem do cultivar, concentração no solo e condições de cultivo (Hendler, 1994).

Ferreira \& Gomes (1996) estudaram a desnutrição mineral na dieta básica da população brasileira e encontraram que o selênio foi o mineral que apresentou-se mais deficitário, com adequação de apenas $24,7 \%$, seguido pelo cálcio, $28,8 \%$ e o zinco, 53,4\%. Os autores calcularam para o ferro adequação de $279,9 \%$ e para o magnésio $119,4 \%$. Entretanto, o ferro presente é de baixa biodisponibilidade e sua absorção poderia ser elevada mediante ingestão simultânea de vitamina C.

Quando se analisa o consumo de alimentos das crianças e adolescentes, observa-se que as principais deficiências nutricionais para as crianças das escolas, sem jornada única, são com relação aos micronutrientes (cálcio, vitamina $A$, vitamina $C$, ferro e vitamina $B_{2}$ ) e os menores déficits ocorrem para caloria, proteína e vitamina $B_{1}$ (Chaim et al., 1996). Tendo em vista que a deficiência nutricional se concentra nos micronutrientes e que suas principais fontes provedoras são frutas e hortaliças, Chaim et al. (1996), analisaram produtos excedentes de comercialização do CEASA e verificaram que a utilização destes produtos, complementaria a deficiência energética e de nutrientes (com exceção ao cálcio) existente nas dietas, mostrando então a viabilidade da utilização dos excedentes de comercialização, para implementação de suplementação nutricional no cardápio de merenda escolar. 
Tendo em vista o inestimável valor nutricional das plantas hortícolas, convém ilustrar os seus teores de vitaminas e minerais (Tabelas 1 e 2)

Tabela 1. Teores das vitaminas $\mathrm{A}$ e $\mathrm{C}$ em hortaliças.

\begin{tabular}{|c|c|c|c|c|}
\hline \multirow{3}{*}{$\begin{array}{c}\text { Hortaliças } \\
\text { in natura }\end{array}$} & \multicolumn{4}{|c|}{ Quantidade de nutrientes em $100 \mathrm{~g}$ de hortaliças } \\
\hline & \multicolumn{2}{|c|}{ Retinol $(\mathrm{mcg})$} & \multicolumn{2}{|c|}{ Ácido ascórbico (mg) } \\
\hline & (1) & (2) & $(1)$ & (2) \\
\hline Batata & 5 & --- & 15,0 & 16 \\
\hline Berinjela & 5 & --- & 1,2 & 5 \\
\hline Brócoli & 350 & 250 & 82,7 & 113 \\
\hline Cenoura & 1.100 & 1.100 & 26,8 & 8 \\
\hline Cebola & 2 & 2 & 13,0 & 10 \\
\hline Pimentão verde & 200 & 245 & 126,0 & 140 \\
\hline Repolho & 10 & 10 & 41,3 & 43 \\
\hline Vagem & 125 & 125 & 23,3 & 27 \\
\hline
\end{tabular}

(1) Franco (1999)

(2) ENDEF (1977)

Tabela 2. Teores de minerais em hortaliças.

\begin{tabular}{|c|c|c|c|c|c|c|c|c|c|c|c|}
\hline \multirow{3}{*}{$\begin{array}{l}\text { Hortaliças } \\
\text { in natura }\end{array}$} & \multicolumn{11}{|c|}{ Quantidade de nutrientes em 100g de hortaliças } \\
\hline & \multicolumn{2}{|c|}{$\mathrm{Ca}(\mathrm{mg})$} & \multicolumn{2}{|c|}{$\mathrm{P}(\mathrm{mg})$} & \multicolumn{2}{|c|}{$\mathrm{Fe}(\mathrm{mg})$} & $\mathrm{Mn}(\mathrm{mg})$ & \multicolumn{2}{|c|}{$\mathrm{Cu}(\mathrm{mg})$} & $\mathrm{Mg}(\mathrm{mg})$ & \multirow{2}{*}{$\begin{array}{l}Z n(m g) \\
(1) \quad(2)\end{array}$} \\
\hline & (1) & (2) & (1) & (2) & (1) & (2) & (1) (2) & (1) & (2) & (1) (2) & \\
\hline Batata & 9 & 15 & 69 & 111 & 1,0 & 1,3 & --- & 0,05 & & 46 & 0,2 \\
\hline Berinjela & 17 & 23 & 29 & 31 & 0,40 & 0,80 & --- & --- & & 90 & --- \\
\hline Brócoli & 400 & 103 & 70 & 78 & 15,0 & 1,10 & --- & 0,84 & & 13 & \\
\hline Cenoura & 56 & 37 & 46 & 36 & 0,60 & 0,70 & 0,60 & 0,14 & & 17 & 0,3 \\
\hline Cebola & 32 & 30 & 44 & 40 & 0,50 & 1,00 & 0,15 & 0,12 & & 12 & --- \\
\hline Pimentão & 12 & 29 & 28 & 61 & 0,40 & 2,60 & 0,26 & 0,10 & & 11 & --- \\
\hline Repolho & 53 & 43 & 32 & 36 & 0,57 & 0,70 & --- & 0,06 & & 35 & --- \\
\hline Vagem & 55 & 43 & 50 & 48 & 1,16 & 1,40 & --- & 0,12 & & --- & --- \\
\hline
\end{tabular}

(1) Franco (1999)

(2) $\operatorname{ENDEF}(1977)$ 


\subsection{Efeitos do processamento no valor nutritivo}

$\mathrm{Na}$ preparação de frutas e hortaliças para serem submetidas ao processamento mínimo, as operações físicas de processamento podem causar lesões e danos nos tecidos dos vegetais. Segundo Watada et al. (1990), a fruta e hortaliça de maior qualidade, seria a selecionada sem ferimentos, ruptura da epiderme e qualquer tipo de dano mecânico. Qualquer ferimento dos tecidos vegetais pode originar uma desordem fisiológica ou contaminação microbiana, seguido de alteração no vegetal.

Os tecidos sofrem menos ferimentos quando são cortados com facas devidamente afiadas. Entretanto, quanto menor for o grau de ferimento, maior será a qualidade e, conseqüentemente, o valor nutritivo. Ohta \& Sugawara (1987) demonstraram que a qualidade de alfaces armazenadas a $5^{\circ} \mathrm{C}$ foi melhor quando estas haviam sido cortadas com facas afiadas.

Em frutas e hortaliças minimamente processadas, existem vários tipos de reações oxidativas, nas quais os elétrons são removidos de átomos e moléculas que passam para sua forma reduzida. Essas reações causam escurecimento, descoloração de pigmentos endógenos, perda ou alterações do flavor dos produtos, alterações na textura, e perda nutricional devido à parcial destruição de vitaminas A,C, D ou E e de ácidos graxos essenciais, como o ácido linoléico (Wiley, 1994).

Carvalho (2000) avaliou os teores de vitamina C de kiwis minimamente processados durante $\mathrm{o}$ armazenamento sob refrigeração de $1^{\circ} \mathrm{C} \pm 0,5^{\circ} \mathrm{C}$. As fatias, com cerca de $1 \mathrm{~cm}$ de espessura, foram submetidas a 4 tratamentos, a saber, imersão em água, imersão em soluções contendo cloreto de cálcio a 1\%, ácido ascórbico a 1\% e ácido cítrico a 1\%. O kiwi tratado com ácido ascórbico apresentou teores mais elevados de vitamina $\mathrm{C}$ quando comparado aos demais tratamentos, indicando que houve absorção da vitamina pelas fatias tratadas, sendo esse aumento de $25 \%$. 
As informações sobre a retenção de ácido ascórbico e vitamina $A$ em frutas e hortaliças frescas e após terem sido submetidas ao branqueamento, em uma quantidade mínima de água, servem como um bom indicador da retenção de nutrientes. Os tomates, que têm $\mathrm{pH}$ ácido, tratados pelo calor, conservam quase todo seu conteúdo de ácido ascórbico, enquanto que as hortaliças com folhas verdes escuras, conservam somente $60 \%$ desta vitamina. As batatas e batatas-doces, as hortaliças com alto teor de amido, bulbo, raízes, além das frutas, apresentam retenção média de ácido ascórbico, da ordem de $75 \%$ (Zagory \& Kader, 1989).

\subsection{Microbiologia dos vegetais minimamente processados}

Frutos e hortaliças são alimentos ricos em vitaminas e sais minerais que possuem alto teor de água livre e teores variáveis de açúcares, lipídeos e proteínas. Rosa et al. (2002) relataram que a seleção da microbiota deteriorante desses alimentos se dá, principalmente, pelo seu teor de nutrientes. Microrganismos proteolíticos, lipolíticos e sacarolíticos crescem mais rapidamente nos alimentos que contêm proteínas, lipídeos e carboidratos, respectivamente, havendo, conseqüentemente, uma seleção de acordo com a composição centesimal do vegetal.

Sob o ponto de vista microbiológico, a composição em nutrientes de um alimento e outros fatores intrínsecos, ao lado dos fatores extrínsecos é que irão selecionar a sua microbiota predominante.

Os vegetais minimamente processados alojam uma microbiota diversificada, freqüentemente, da ordem de $10^{5}$ a $10^{7} \mathrm{UFC} / \mathrm{g}$. A população bacteriana é composta por 80 a $90 \%$ de bacilos Gram negativos, predominantemente pertencentes aos gêneros Pseudomonas, Enterobacter e Erwinia (Marchetti et al., 1992). Bactérias ácido-láticas têm sido encontradas em saladas mistas e cenouras minimamente processadas submetidas a temperatura de $30^{\circ} \mathrm{C}$ (Manvell \& Ackland, 1986). Os fungos usualmente 
isolados nesses vegetais são Cryptococcus, Rhodotorula e Candida (Brackett, 1994).

Doenças de origem alimentar, causadas por patógenos, têm sido associadas a esses vegetais. Os patógenos mais freqüentemente associados são Listeria monocytogenes, Clostridium botulinum, Aeromonas hydrophila, Salmonella, Escherichia coli O157:H7, Yersinia enterocolitica, Campilobacter jejuni, vírus e protozoários (Francis et al., 1999).

Calcula-se que $20 \%$ das frutas e hortaliças utilizadas para o consumo humano são perdidas como conseqüência de alterações microbianas, cujos principais agentes causadores dessas alterações são as bactérias, leveduras e os fungos (Jay, 1994).

Uma preocupação particular em relação a $L$. monocytogenes é a sua capacidade de crescer sob temperaturas de refrigeração. A temperatura mínima de crescimento é de $-0,4^{\circ} \mathrm{C}$ e por ser uma bactéria anaeróbia facultativa, é capaz de crescer em baixas concentrações de $\mathrm{O}_{2}$; o seu desenvolvimento pode, portanto, ser favorecido em vegetais minimamente processados e embalados em atmosfera modificada (Walker \& Stringer, citado por Francis et al., 1999).

Devido a $L$. monocytogenes ter ocorrência natural no ambiente, encontrase presente na maioria dos vegetais. A contaminação dos vegetais por essa bactéria pode se dar através das práticas de cultivo, de irrigação e através do uso de fertilizantes (Nguyen-The \& Carlin, 1994).

A Listeria monocytogenes pode estar presente e pode sobreviver no ambiente e em muitos tipos de vegetais processados, particularmente, quando encontra condições favoráveis de umidade (Farber \& Peterkin, 1991). Tem sido isolada nas operações de preparo de vegetais (Zhang \& Farber, 1996). A operação de corte dos vegetais pode aumentar a contaminação por $L$. monocytogenes. Segundo Velani \& Roberts (1991), esse patógeno foi detectado em $19 \%$ de amostras de salada mista de vegetais, considerando que apenas $1,8 \%$ dos ingredientes individuais estavam contaminados. 
A contaminação pode acontecer durante o corte, montagem e empacotamento dos vegetais. Um caso de presença de L. monocytogenes foi relatado em repolho fatiado como conseqüência do uso de equipamentos de corte da linha de processamento contaminados (Nguyen-The \& Carlin, 1994). No experimento de Nguyen-The \& Carlin (1994) a L. monocytogenes cresceu melhor em salada mista composta de endívia e milho do que em endívia apenas, quando armazenadas a $6^{\circ} \mathrm{C}$ e $9^{\circ} \mathrm{C}$.

A $A$. hidrophyla é uma bactéria que possui algumas características que favorecem o seu crescimento em vegetais minimamente processados, é psicrotrófica tendo seu ótimo de crescimento a temperatura de 4 a $5^{\circ} \mathrm{C}$, crescendo também a $0^{\circ} \mathrm{C}$ em alimentos. É anaeróbia facultativa e capaz de crescer em atmosferas contendo baixas concentrações de oxigênio (Francis et al., 1999).

Marchetti et al. (1992) isolaram $A$. hidrophyla em saladas de vegetais minimamente processadas; a contagem foi da ordem $10^{3}$ a $10^{4} / \mathrm{g}$. Aeromonas spp. foram também isoladas de saladas verdes, salada de repolho e salada mista de vegetais (Hudson \& DeLacy, 1991).

Tassinari et al. (1994) informaram que Yersinia spp. tem sido isolada em 3,3 a $46,1 \%$ dos vegetais. A $Y$. enterocolitica cresce na faixa de $\mathrm{pH}$ de 4 a 9 , assim é possível controlar o seu crescimento em alimento com pH menor que 4. Esses microrganismos, inoculados artificialmente, têm apresentado pouca sobrevivência em molhos ácidos para saladas (Brackett, 1986).

As propriedades antagônicas das bactérias ácido láticas têm sido estudadas. As bactérias ácido láticas mostram efeitos antimicrobianos devido a um ou mais dos mecanismos seguintes: redução do $\mathrm{pH}$, produção de peróxido de hidrogênio, competição por nutrientes e produção de antimicrobianos como bacteriocinas (Piard \& Desmazeaud, 1992; Arihara et al., 1993). 


\subsection{Contaminação microbiana de vegetais}

O desenvolvimento de microrganismos patogênicos em vegetais minimamente processados vai depender de suas características, propriedades intrínsecas do vegetal e dos efeitos do processamento, embalagem e armazenamento. Cada produto a ser processado passa por uma série de etapas, incluindo manipulação, lavagem, contato com os equipamentos, empacotamento e armazenamento. Cada uma dessas etapas pode interferir no crescimento e sobrevivência dos microrganismos (Francis et al., 1999).

Os vegetais in natura podem estar contaminados por patógenos quando entram na linha de processamento (Nguyen-The \& Carlin, 1994). A matériaprima e sua procedência determinarão o tipo e a quantidade de microrganismos inicialmente presentes. Análises efetuadas em etapas distintas do processamento demonstram que o produto final é menos contaminado que as hortaliças no início do processamento. No entanto, a contaminação microbiana pode também ocorrer durante o processamento e distribuição, devendo então, ser aplicadas práticas de higiene em todas as etapas (King et al., 1991).

A contaminação durante o processamento pode ocorrer devido a falhas de higiene do pessoal ou por contato do vegetal com equipamentos inadequadamente limpos. A manipulação deve ser feita corretamente para evitar danos ao produto fresco, desperdício de vegetais e contaminação por microrganismos deterioradores e patogênicos (Brackett, 1994).

Os equipamentos utilizados para o processamento podem ser potenciais fontes de contaminação do vegetal, pois normalmente possuem partes de difícil higienização onde as bactérias se alojam (Garg et al., 1990). A presença de superfícies irregulares no equipamento permite infiltração microbiana, fornecendo condições para o crescimento e desenvolvimento dos microrganismos (Brackett, 1994).

O excesso de umidade e o exsudado liberado nas superfícies do corte dos tecidos e em utensílios e equipamentos, proporcionam o rápido 
crescimento dos microrganismos. Sendo assim, durante o fatiamento do produto, pode haver um aumento no número de bactérias presentes. Os vegetais submetidos a vários cortes resultam num aumento da população microbiana de 6 a 7 vezes (Brackett, 1994).

A qualidade microbiológica de hortaliças minimamente processadas foi pesquisada por vários autores como Manvell \& Ackland (1986) em salada mista de repolho, cenoura, cebola e pimentão; Garg et al. (1990) em couve-flor e espinafre; Kallander et al. (1991) em repolho; Bennik et al. (1996) em almeirão; Nguyen-The et al. (1996) em chicória; Robbs et al. (1996) em aipo; Francis \& O'Beirne (1997) em alface; Jacksens et al. (2002) em salada mista de alface, pimentão e pepino e Valero et al. (2002) em alho e em geral, os produtos são seguros quando processados em condições de higiene e armazenados sob temperatura de refrigeração.

Sagoo et al. (2003) avaliaram saladas ready-to-eat e constataram que de 3852 amostras analisadas, 99,3\% estavam satisfatórias ou aceitáveis pelos padrões do Public Health Laboratory Service, enquanto que 0,5\% estavam insatisfatórias devido aos níveis acima de 1,0 × 10² UFC/g de Escherichia coli e Listeria spp., 0,2\% apresentaram Salmonelas e 6,6 × $10^{2} \mathrm{UFC} / \mathrm{g}$ de $L$. monocytogenes, fato que representa risco àsaúde do consumidor. Os autores informaram, de imediato, à UK Food Standards Agency a respeito do estabelecimento.

A temperatura de refrigeração abaixo de $7^{\circ} \mathrm{C}$, utilizada no armazenamento de frutas e hortaliças minimamente processadas, embora prolongue a vida útil desses produtos, diminuindo a velocidade de crescimento dos microrganismos, são seletivas para microrganismos psicrotróficos. A presença de bactérias mesófilas e psicrotróficas em alface e repolho e chicória, foi relatada por alguns autores (Nguyen The et al., 1996; Zhang \& Farber, 1996). 


\subsection{Outros patógenos de ocorrência em vegetais}

Um grupo de patógenos causadores de doenças de origem alimentar que tem recebido pouca atenção, em países em desenvolvimento são os protozoários, parasitas comuns que ocorrem em vegetais frescos, como a Giardia lamblia, Entamoeba histolytica e Ascaris spp. (Brackett, 1987). Esses organismos, normalmente, contaminam os vegetais antes da colheita, através da água de irrigação e falta de higiene durante práticas culturais. Em um surto de giardíase, a evidência epidemiológica tem sido atribuída a manipuladores de alimentos, portadores assintomáticos, como provável fonte de G. lamblia e hortaliças fatiadas como veículo de trans missão (Beuchat, 1996).

\subsection{Sanificação de vegetais}

O primeiro passo para a redução da contaminação dos vegetais é a remoção da superfície suja ou da casca e após, os vegetais são cortados, lavados e imersos em soluções contendo sanificante. Esses processos reduzem a carga microbiana inicial e, conseqüentemente, a população de patógenos. A lavagem pode ser apenas com água, porém sua eficácia é melhorada com a adição de sanificante, mais usualmente o cloro, ácido cítrico e ácido ascórbico (Reyes, 1996). Porém, se a água for reutilizada, a sanificação ficará comprometida (Brackett, 1992). É recomendado a troca da solução sanificante após duas ou três vezes de uso ou quando o teor de cloro ativo for menor que $100 \mathrm{mg} \mathrm{L}^{-1}$ (Moretti, 2000). A remoção do excesso de água adicionado durante a lavagem é feita na etapa seguinte, da centrifugação (Reyes, 1996). 


\subsubsection{Cloro}

O cloro nas suas várias formas é o sanificante mais utilizado em alimentos. Os compostos àbase de cloro são bactericidas que reagem com as proteínas da membrana da célula microbiana, interferindo no transporte de nutrientes e promovendo a perda de componentes celulares (Dychdala, 1991).

Concentrações de 50 a $200 \mathrm{mg} \mathrm{L}^{-1}$ de cloro são, geralmente, utilizadas para sanificar frutas e hortaliças frescas, bem como produtos minimamente processados em escala comercial, porém, tratamentos inadequados com soluções de cloro podem não reduzir, efetivamente, a população de microrganismos deteriorantes ou patogênicos como a Listeria monocytogenes (Beuchat \& Brackett, 1990; Beuchat et al., 1998).

Um importante passo para o processamento mínimo é a lavagem dos vegetais e após, a imersão em soluções antimicrobianas. A lavagem com água, contendo cloro livre, em uma concentração de $100 \mathrm{mg} \mathrm{L}^{-1}$, tem sido usada em folhas de alface para reduzir o número de bactérias, em até 100 vezes (Adams et al., 1989).

Prado et al. (2000) estudaram a influência do hipoclorito de sódio nas concentrações de 100 e $200 \mathrm{mg} \mathrm{L}^{-1}$ e $85 \%$ de UR sobre a qualidade de abacaxis da cultivar Pérola, minimamente processados, através de análises de líquido drenado, textura, $\mathrm{pH}$, acidez total, acidez titulável, sólidos solúveis totais, componentes microbiológicos e avaliação sensorial. Os autores concluíram que o hipoclorito de sódio, nessas concentrações, não influencia na qualidade dos frutos armazenados por 6 dias. Já em melões minimamente processados, 0 tratamento com soluções de hipoclorito nas concentrações de 100 e $200 \mathrm{mg} \mathrm{L}^{-1}$ embora não tendo influenciado a qualidade microbiológica e sensorial, afetou levemente a textura e o teor de sólidos solúveis (Araújo et al., 2000).

Fatores como $\mathrm{pH}$, temperatura, matéria orgânica e concentração do sanificante determinam a eficiência da solução à base de cloro (Dychdala, 1991). A manutenção do pH da solução entre 6,5 e 7,5 é de extrema 
importância para o sucesso da etapa de sanificação (Moretti, 2000). O pH próximo a 7,0 mantém o cloro na sua forma ativa de ácido hipocloroso (Brecht, 1995). Considerando que o pH da água possui impacto significativo sobre a atividade do cloro, torna-se muito importante seu ajuste na água que será utilizada junto ao sanificante (Hurst, 1995).

Fantuzzi (1999) informou que a sanificação de repolhos inteiros usando três soluções, a de hipoclorito de sódio $200 \mathrm{mg} \mathrm{L}^{-1}$, Sumaveg ${ }^{\circledR}$-DiverseyLever 0,66\% e ácido acético $1 \%$ durante $10 \mathrm{~min}$, àtemperatura ambiente, resultou na redução de até 1,8 ciclos logarítmicos da população de microrganismos aeróbios mesófilos sem diferenças significativas ( $p>0,05)$, entre as três soluções avaliadas.

Freire (1999) sanificou alface hidropônico, do cultivar Regina, minimamente processado, utilizando $100 \mathrm{mg} \mathrm{L}^{-1}$ de cloro livre em água mantida a 5 a $8^{\circ} \mathrm{C}$ e a pH 7,0 durante $15 \mathrm{~min}$; o alface foi armazenado a $2^{\circ} \mathrm{C}$ e $10^{\circ} \mathrm{C}$. $\mathrm{O}$ autor concluiu que para as temperaturas testadas, até o terceiro dia do experimento, não houve nenhum comprometimento do produto para qualquer um dos aspectos de qualidade analisados. As amostras armazenadas a $2^{\circ} \mathrm{C}$, apresentaram vida útil de 7 dias, sem comprometer suas características físicas, físico-químicas, bioquímicas e sensoriais. Já o produto armazenado a $10^{\circ} \mathrm{C}$ apresentou vida útil de 3 dias devido, principalmente, ao aumento acentuado da atividade das enzimas polifenoloxidase e fenilalanina amonia-liase com conseqüente degradação da clorofila; após 7 dias houve crescimento de bactérias psicrotróficas patogênicas.

Existem preocupações quanto ao uso de bactericidas. Os patógenos que estão presentes em vegetais crus, podem não ser completamente eliminados através dos procedimentos de desinfecção comercial, e ao mesmo tempo a desinfecção pode reduzir ou remover os microrganismos competitivos naturais.

Os efeitos do hipoclorito de sódio em $L$. monocytogenes têm sido amplamente estudados in vitro, mostrando grande eficácia (Tuncan, 1993). Porém, a eliminação de L. monocytogenes da superfície de hortaliças através 
da desinfecção é limitada. A solução de hipoclorito pode não ter um bom contato com o vegetal, devido æ̀ superfícies hidrofóbicas destes e assim o cloro não penetra nas aberturas naturais do vegetal (Adams et al., 1989).

Zhuang et al. (1995) examinaram a eficácia do tratamento com cloro na inativação da Salmonella montevideo em tomates. Populações da $S$. montevideo presentes na superfície e nos tecidos internos foram substancialmente reduzidas, quando os tomates foram imersos em soluções contendo 60 e $100 \mathrm{mg} \mathrm{L}^{-1}$ de cloro, respectivamente.

Park et al. (1991) estudaram a eficácia do hipoclorito de sódio no controle da contaminação por $S$. enteritidis em cenoura e abobrinha. Esses autores concluíram que a solução sanificante foi muito eficaz na redução da população de Salmonella, pois com 20 min. de exposição dos vegetais ao sanificante, a contagem foi inferior a 2 UFC/g.

A lavagem de hortaliças com $50 \mathrm{mg} \mathrm{L}^{-1}$ de cloro livre na água reduziu significativamente a contagem total de aeróbios mesófilos. Já os coliformes fecais se mostraram mais sensíveis ao cloro, não sendo detectados após lavagem com 10, 20 ou $50 \mathrm{mg} \mathrm{L}^{-1}$ (Mazzollier, citado por Nguyen-The \& Carlin, 1994).

\subsection{2 Ácidos orgânicos}

Os ácidos orgânicos se encontram entre os mais utilizados como conservadores de alimentos. O efeito bactericida existentes nos ácidos propiônico, acético, lático e cítrico, se deve tanto ao decréscimo do $\mathrm{pH}$, abaixo do intervalo de crescimento dos microrganismos, quanto à inibição do metabolismo microbiano pelas moléculas de ácidos não dissociadas, que penetram na célula microbiana acidificando o seu interior e causando danos ou destruindo-a (Jay, 1994).

Piagentini et al. (2000) analisaram o efeito combinado do ácido cítrico, ácido ascórbico e tipo de embalagem sobre a qualidade sensorial, retenção de 
clorofila e perda de peso de espinafre minimamente processado, durante 0 armazenamento refrigerado a $4^{0} \mathrm{C}$ e $90 \%$ de UR. Concluíram que os tratamentos químicos aplicados e os tipos de filmes utilizados não afetaram a retenção da clorofila total e a perda de peso ao longo dos 14 dias de armazenamento. Porém, o tempo de armazenamento afetou significativamente os atributos sensoriais analisados; os tipos de filmes utilizados afetaram significativamente o desenvolvimento de odor desagradável.

\subsection{Efeito dos gases nos vegetais}

A diminuição do $\mathrm{O}_{2}$ e a elevação do $\mathrm{CO}_{2}$ exercem efeitos independentes e, em muitos casos sinergísticos sobre a respiração dos vegetais e sobre outros processos metabólicos. A velocidade da respiração reduz-se com baixos teores de $\mathrm{O}_{2}$ devido a redução da produção de etileno nos tecidos vegetais. Altos teores de $\mathrm{CO}_{2}$ inibem tanto a síntese como a ação do etileno. Contudo, concentrações muito baixas de $\mathrm{O}_{2}$ ou muito altas de $\mathrm{CO}_{2}$, ou ainda a relação $\mathrm{CO}_{2} / \mathrm{O}_{2}$ alta, podem levar à respiração anaeróbica e a desordens fisiológicas, como amadurecimento irregular, desenvolvimento de sabor/odor estranhos e aumento da susceptibilidade àdeterioração (Sarantópoulos, 2001).

A redução nos níveis de $\mathrm{O}_{2}$ e $\mathrm{o}$ aumento de $\mathrm{CO}_{2}$ têm como conseqüência, a redução da taxa de respiração e produção de etileno, e a desaceleração das mudanças metabólicas ligadas ao amadurecimento. Entretanto, a deterioração pós-colheita é causada por vários fatores além da respiração como injúrias mecânicas, perda de água, desordens fisiológicas e metabólicas e deterioração microbiana (Zagory \& Kader, 1988).

A respiração é considerada como o melhor indicador da atividade metabólica da célula e a redução de sua intensidade promove a diminuição da taxa de metabolismo como um todo (Lana \& Finger, 2000). A manutenção de um mínimo de $1 \%$ a $3 \%$ de $\mathrm{O}_{2}$ é necessário para evitar a mudança da respiração de aeróbica para anaeróbica. Apesar da respiração anaeróbica 
ocorrer quando os níveis de $\mathrm{O}_{2}$ interno dos tecidos são da ordem de 0,2\% ou menos; níveis da ordem de $1 \%$ a $3 \%$ ao redor do produto são requeridos, dependendo da taxa respiratória e das características de difusão gasosa dos tecidos de cada produto específico (Kader, 1986). Concentrações de $\mathrm{CO}_{2}$ entre $5 \%$ e $20 \%$ reduzem, efetivamente, a taxa respiratória da maioria dos produtos hortícolas. O aumento da respiração, que pode ocorrer em alguns produtos associado à elevação da concentração de $\mathrm{CO}_{2}$, pode ser conseqüência da injúria causada pelo excesso do gás (Mathooko, 1996).

A exposição ao $\mathrm{O}_{2}$ pode reduzir as taxas de respiração e produção de etileno, dependendo do vegetal, estágio de maturação, concentração de $\mathrm{Q}_{\text {, }}$ tempo de armazenamento e temperatura, e concentração de $\mathrm{CO}_{2}$ e $\mathrm{C}_{2} \mathrm{H}_{4}$ presentes ra atmosfera. Em alguns vegetais cianeto-resistentes, a respiração é aumentada sob atmosfera com elevada concentração de $\mathrm{O}_{2}$. Em frutos climatéricos, a respiração é pouco aumentada por exposição ao $\mathrm{O}_{2}$ em concentrações de 30 a $80 \%$, porém em $80 \%$ de $\mathrm{O}_{2}$, o amadurecimento é retardado, pelo fato do $\mathrm{O}_{2}$ ser tóxico para algumas frutas. Altas concentrações de $\mathrm{O}_{2}$ aumentam os efeitos do etileno em frutas e hortaliças frescas, incluindo amadurecimento, senescência e desordem fisiológica, além de detecção de gosto amargo, em cenouras (Kadera \& Ben-Yehoshuab, 2000).

Existem poucas informações disponíveis para o caso de vegetais submetidos a elevados níveis de $\mathrm{O}_{2}$, no que se refere à concentração de vitaminas, minerais e fibras dietéticas, em frutas e hortaliças frescas minimamente processadas. Kadera \& Ben-Yehoshuab (2000) demonstraram que houve diminuição do ácido ascórbico contido em tubérculos de batata, quando armazenados a $100 \%$ de $\mathrm{O}_{2}$, Os autores informam que altas concentrações de $\mathrm{O}_{2}$ em alfaces minimamente processadas colaboraram para a diminuição dos antioxidantes naturais.

Bezerra (2000), avaliando as alterações na composição química de mandioca cultivar Baianinha, mostrou que raízes branqueadas e embaladas a vácuo, armazenadas a 8을 apresentaram-se livres de sintomas de deterioração 
fisiológica até $01^{\circ}$ dia de armazenamento. A deterioração por Fusarium somente ocorreu após o 15ํㅡㄹ dia. Porém, as raízes tornaram-se impróprias para o consumo, em relação à aparência e sabor, a partir do 9o dia de armazenamento.

\subsection{Embala gens para hortaliças}

O mercado brasileiro de embalagens com atmosfera modificada tem crescido significativamente nos últimos anos, tanto em quantidade de tipos de embalagens, quanto em diversidade de produtos embalados com essa tecnologia. Os avanços mundialmente observados no desenvolvimento das embalagens flexíveis para 0 acondicionamento desses alimentos, principalmente no tocante à oferta de uma extensa gama de filmes plásticos com diferentes graus de permeabilidade gasosa, muito têm contribuído para aumentar o interesse por esse mercado, induzindo a uma crescente adoção de práticas de conservação das hortaliças, em embalagens com atmosfera modificada (Junqueira \& Luengo, 1999).

Teixeira et al. (2001) demonstraram que mamões do grupo "Formosa", podem ser utilizados para o processamento mínimo, na forma de pedaços $(2,5$ x $2,5 \mathrm{~cm}$ e $2,5 \mathrm{~cm} \times 5,0 \mathrm{~cm}$ ) e embalados em copos plásticos de $500 \mathrm{~mL}$. Nas temperaturas de $3^{\circ} \mathrm{C}, 6^{\circ} \mathrm{C}$ e $9^{\circ} \mathrm{C}$, estes produtos, quando produzidos dentro de padrões higiênicos adequados, podem ser conservados por 7 dias, sem apresentar alterações físico-químicas ou sensoriais significativas.

Fantuzzi (1999) avaliou o efeito de três tipos de embalagem na conservação de repolho minimamente processado. As amostras de repolho mantidas a $12^{\circ} \mathrm{C}$ tornaram-se impróprias para o consumo após 5 dias de armazenamento, independente do tipo de filme plástico utilizado. Após 15 dias, as amostras acondicionadas em bandejas transparentes, seladas com filme de PVC termoencolhível, apresentaram também sinais de deterioração. Nas embalagens de polietileno PD900 e PD961 EV (Cryovac ${ }^{\circledR}$ ), a $1^{\circ} \mathrm{C}$ e $5^{\circ} \mathrm{C}$, o 
repolho minimamente processado manteve-se, em condições adequadas de conservação até o vigésimo dia de estocagem. As contagens iniciais de aeróbios mesófilos e psicrotróficos foram de $10^{4} \mathrm{UFC} / \mathrm{g}$ e não variaram, significativamente, no decorrer da estocagem, nas três embalagens. A contagem inicial de microrganismos anaeróbios foi de $10^{3} \mathrm{UFC} / \mathrm{g}$ e não se alterou com o tempo, possivelmente em razão da manutenção de concentrações relativamente altas de $\mathrm{O}_{2}$ no interior das embalagens.

Vasconcelos (2000) demonstrou que há redução na degradação de açúcares totais e na perda de massa em caquis, cultivar Fuyu, armazenados durante 42 dias a $2^{\circ} \mathrm{C}$, em embalagem "CF-filme", produzida a partir de polietileno de baixa densidade e impregnado com uma mistura de mineral ativado absorvente de etileno. Esses frutos tratados com cloreto de cálcio a $2 \%$, apresentaram menor solubilização de pectina solúvel e menor atividade da enzima pectinametilesterase, favorecendo o atraso no amadurecimento e maior retenção de hemicelulose.

Os vegetais são normalmente embalados em pacotes de filmes semipermeáveis. Os vegetais respiram, modificando a atmosfera dentro da embalagem. As concentrações de $\mathrm{O}_{2}$ utilizadas são de 2 a $3 \%$ e de $\mathrm{CO}_{2}, 3$ a $10 \%$. Os gases combinados juntamente com a refrigeração reduzem a respiração do produto e diminuem o crescimento microbiano, diminuindo o metabolismo fisiológico e estendendo a vida útil do alimento (O’Beirne \& Ballantyne, 1987).

Di Pentima et al. (1996) não encontraram diferenças significativas nas características sensoriais quanto a aparência e coloração e na observação do murchamento em brócolis, folhas inteiras de espinafres e aspargos prontos para o uso, embalados em diferentes tipos de filmes plásticos flexíveis e armazenados a $4^{\circ} \mathrm{C}$. Entretanto, foram encontradas diferenças no desenvolvimento de odor desagradável de acordo com o filme utilizado, sendo maiores em filmes de menor permeabilidade. 
Em alguns aspectos, a embalagem a vácuo é semelhante àda atmosfera modificada, sendo a principal diferença o fato de que, na primeira existe a remoção da maior parte do ar de dentro da embalagem, sem a substituição por uma outra mistura gasosa (Omati \& Godoy, 1996).

Durante os últimos 50 anos, tem-se utilizado o armazenamento com atmosfera controlada e atmosfera modificada, como um sistema que aumenta a vida útil de muitas frutas, incluindo maçãs, bananas, kiwis e morangos (Lewis \& Shibamoto, 1986). O armazenamento com atmosfera controlada (AC) e atmosfera modificada (AM), requer um reduzido nível de $\mathrm{O}_{2}$, ajuste da concentração de $\mathrm{CO}_{2}$ e o controle do nível de etileno. $\mathrm{O}$ armazenamento com AC e AM pode ser conduzido em embalagens completamente herméticas, em recipientes para transporte a longa distância e em embalagens individuais (Labuza \& Breene, 1989).

Segundo Perdue (1989), as frutas e hortaliças, por si, podem modificar a atmosfera dentro da embalagem. Envolvidas individualmente em filmes retráteis, sofrem decréscimo na respiração, com aumento da vida útil e manutenção da umidade. Existem diferentes sistemas de atmosfera modificada, utilizados em maçãs e pêras intactas, além de armazéns e recipientes para transporte com atmosfera controlada. A embalagem com nitrogênio é utilizada para transporte de alfaces em caixas limpas, e prontas para uso no comércio; enquanto que alfaces cortadas e picadas a granel, geralmente embaladas a vácuo, são transportadas como alimentos apropriados para o preparo rápido de saladas, em restaurantes.

\subsection{Embalagem com Atmosfera modificada}

A técnica de acondicionamento em atmosferas modificadas foi descoberta por acaso no final do século XIX. Percebeurse benefícios ou melhorias nas carcaças de animais transportadas da Austrália para Europa sob refrigeração em gelo seco. (Farber, 1991). 
A conservação de produtos hortícolas em condições de atmosfera modificada ( $A M)$ e controlada ( $A C)$ pode ser definida como o armazenamento realizado sob condições de composição da atmosfera, diferente daquela presente normalmente no ar atmosférico. Neste, $0 \mathrm{O}_{2}$ está presente na concentração de $21 \%$, enquanto que o $\mathrm{CO}_{2}$ apresenta-se com concentração de $0,03 \%$, além de $78 \%$ de $\mathrm{N}_{2}$ e outros gases. Tanto no armazenamento em atmosfera modificada, como controlada, há redução da concentração de $\mathrm{O}_{2} \mathrm{e}$ aumento do $\mathrm{CO}_{2}$. Os limites mínimos para a concentração final de $\mathrm{O}_{2}$ e máximos para a de $\mathrm{CO}_{2}$ são determinados pelo comportamento fisiológico do produto, em condições de anaerobiose parcial, e sob injúria de $\mathrm{CO}_{2}$ durante $\mathrm{o}$ armazenamento (Lana \& Finger, 2000).

$\mathrm{Na}$ atmosfera controlada, os níveis de gases da atmosfera são monitorados periodicamente e são ajustados de modo a manter-se as concentrações desejadas. A mistura gasosa desejada é injetada nas câmaras, hermeticamente fechadas, onde os produtos são armazenados (Zagory \& Kader, 1988).

Em condições de atmosfera modificada os níveis dos gases presentes no ar não sofrem controle completo. A presença de uma barreira artificial àdifusão de gases em torno da fruta ou hortaliça resulta em redução do nível de $\mathrm{O}_{\text {, }}$ aumento do nível de $\mathrm{CO}_{2}$, alteração das concentrações de etileno e vapor de água, e alteração de outros compostos voláteis. A magnitude dessas alterações é dependente da natureza e espessura da barreira, taxa respiratória do produto, relação entre massa do produto e área superficial da barreira, temperatura e umidade. Como a composição final da atmosfera não é controlada, mas resultante da interação da barreira entre o produto e o ambiente, o termo AM é utilizado para diferenciar essa técnica da $A C$ convencional.

Dependendo do mecanismo pelo qual se estabelece a atmosfera no interior da embalagem pode-se ter armazenamento em atmosfera passiva ou ativa. 
A atmosfera modificada ativa é obtida através da reposição da atmosfera do interior da embalagem por misturas gasosas, em concentração préestabelecida. Promove-se o vácuo moderado na embalagem que contém produto e injeta-se a mistura de gases desejada antes da selagem da mesma (Chitarra, 1998).

A atmosfera modificada passiva é obtida através do controle das trocas gasosas através da própria embalagem. O ambiente atmosférico desejado é atingido por meio da respiração do produto e das trocas gasosas (difusão de $\mathrm{O}_{2}$ e $\mathrm{CO}_{2}$ ) através da embalagem com o meio externo (Chitarra, 1998).

Saltveit (2003) discute que a variabilidade natural das matérias-primas e a sua resposta dinâmica às condições de processamento e estocagem podem tornar inviável identificar uma atmosfera ótima para embalamento dos vegetais. Geralmente, as recomendações estabelecidas para as características das embalagens sob atmosfera modificada ou atmosfera controlada, nos experimentos, são empíricas. Normalmente são 6 os componentes sob análise: vida útil, temperatura, umidade relativa, níveis de $\mathrm{O}_{2}, \mathrm{CO}_{2}$ e de etileno. Entretanto, a variabilidade inerente a cada vegetal em foco, somada aos componentes em julgamento tornam impossível estabelecer-se um modelo matemático ideal.

\subsubsection{Controle dos microrganismos em atmosfera modificada}

A atmosfera modificada é considerada, após a refrigeração, o método mais efetivo para estender a vida útil e o frescor dos produtos minimamente processados. É uma tecnologia inovadora e as pesquisas em andamento devem permitir a determinação dos seus efeitos em relação ao crescimento de microrganismos deterioradores e patógenos e a qualidade dos produtos embalados (Francis et al., 1999).

O modo pelo qual o $\mathrm{CO}_{2}$ exerce sua influência na célula bacteriana pode ser a ocorrência de uma alteração na função da célula bacteriana, incluindo 
efeitos na absorção de nutrientes, a inibição direta de enzimas ou decréscimo na taxa de reações enzimáticas, a penetração na membrana bacteriana, levando a mudanças no pH intracelular e mudanças diretas nas propriedades físico-químicas das proteínas (Farber, 1991).

Quanto ao $\mathrm{O}_{2}$, este geralmente estimula o crescimento de bactérias aeróbicas e pode inibir o crescimento de bactérias estritamente anaeróbicas. Já o № é um gás inerte, que apresenta pouca ou nenhuma atividade microbiana, podendo, ao deslocar $\mathrm{O} \mathrm{O}_{2}$ na embalagem, retardar a rancidez oxidativa e também inibir o crescimento de microrganismos aeróbicos (Farber, 1991).

Frutas e hortaliças minimamente processadas devem ser armazenadas na faixa de temperatura de $2^{\circ} \mathrm{C}$ a $5^{\circ} \mathrm{C}$. A temperatura de refrigeração deve ser estritamente controlada para limitar o crescimento de patógenos e microrganismos deteriorantes (Francis et al., 1999).

A temperatura de armazenamento, provavelmente, é o fator mais importante que pode afetar o crescimento de microrganismos em vegetais minimamente processados. Foram publicadas pelo instituto inglês de ciência e tecnologia de alimentos, em 1990, diretrizes a serem seguidas para o controle da refrigeração de alimentos, recomendando o armazenamento $0^{\circ} \mathrm{C}$ e $5^{\circ} \mathrm{C}$ para as saladas pré-prontas, considerando-se que abaixo desta faixa de temperatura os vegetais podem sofrer danos (Francis et al., 1999).

O armazenamento de vegetais minimamente processados sob temperaturas adequadas de refrigeração limita 0 crescimento de microrganismos patogênicos psicrotróficos. Algumas pesquisas mostraram que a Listeria monocytogenes sobrevive ou cresce em vários tipos de vegetais prontos para o uso como alface fatiada (Beuchat \& Brackett, 1990), repolho fatiado (Kallander et al., 1991) e vegetais frescos (intactos) sob temperaturas de refrigeração (Berrang et al., 1989).

Existe, portanto, uma preocupação com os patógenos como Listeria monocytogenes, que se desenvolvem sob temperatura de refrigeração. Berrang 
et al. (1990) demonstraram que esses microrganismos continuaram crescendo em aspargos, mesmo com a manutenção das qualidades sensoriais.

Beuchat \& Brackett (1990) demonstraram que a população de Listeria monocytogenes em alface aumentou, significativamente, durante 0 armazenamento e as embalagens contendo $3 \%$ de $\mathrm{O}_{2}$ e $97 \%$ de $\mathrm{N}_{2}$ não influenciaram na taxa de crescimento da bactéria.

A contagem de Aeromona hydrophila em vegetais minimamente processados foi aumentada de $10^{3}$ a $10^{4} \mathrm{UFC} / g$ chegando a $10^{6}$, após 7 dias de armazenamento a 3 - 5으 (Marchetti et al., 1992).

A temperatura de armazenamento, além do seu efeito direto no crescimento bacteriano, também determina a taxa de respiração do produto e, pode ser responsável por alterações na atmosfera da embalagem e influenciar o comportamento dos patógenos (Dixon \& Kell, 1989).

García-Gimeno et al. (1996) estudaram o crescimento de A. hydrophila em saladas de vegetais estocadas sob atmosfera modificada, a $4^{\circ} \mathrm{C}$ e $15^{\circ} \mathrm{C}$ e mostraram que as bactérias sobreviveram, mas não cresceram, em amostras armazenadas a $4^{\circ} \mathrm{C}$. Entretanto, cresceram de $10^{3}$ para $10^{8} \mathrm{UFC} / \mathrm{g}$ nas primeiras $24 \mathrm{~h}$, quando as saladas foram armazenadas a $15^{\circ} \mathrm{C}$.

Com o aumento da vida útil do produto, há também aumento no tempo disponível para o crescimento dos patógenos, e conseqüente, desenvolvimento de uma significativa população bacteriana. Embora a embalagem dos vegetais com concentrações de $\mathrm{O}_{2}$ de 2 a $5 \%$ deva inibir, obrigatoriamente, 0 crescimento de microrganismos anaeróbios como Clostridium botulinum, se for submetida a temperatura de abuso pode haver o desenvolvimento desses microrganismos, como resultado do aumento da respiração do produto. A preocupação se deve ao crescimento de microrganismos psicrotróficos, anaeróbios facultativos, que podem tolerar os baixos níveis de oxigênio existentes na embalagem com atmosfera modificada (Bennik et al., 1998). 
Em geral, concentrações de 50 a $100 \%$ de $\mathrm{CO}_{2}$ reduzem o crescimento de Salmonella, mas estas concentrações podem causar dano à maioria dos vegetais minimamente processados (Baker et al., 1986).

Huxsoll \& Bolen (1989) revisaram o armazenamento de alimentos sob atmosfera controlada e modificada no processamento mínimo, mostrando os efeitos do $\mathrm{SO}_{2}, \mathrm{CO}_{2}$ e temperatura $\left(4^{\circ} \mathrm{C}\right.$ e $\left.21^{\circ} \mathrm{C}\right)$ na inibição da peroxidase, polifenoloxidase (PFO) e pectinesterase (PE), e concluíram que existe menor efeito destes gases na enzima PE que na PFO.

\subsubsection{Atmosfera modificada e nutrientes}

Os teores de ácido ascórbico de frutas e hortaliças armazenadas em atmosfera controlada, variam com a atmosfera, tipo de produto e temperatura de armazenamento. Os teores de vitamina $A$ em frutas e hortaliças, podem ser conservados quando as condições de atmosfera controlada mantiverem baixo nível de $\mathrm{O}_{2}$ e umidade relativa elevada (Zagory \& Kader, 1989).

Wang (1983) estudou o efeito da atmosfera modificada, com alto teor de $\mathrm{CO}_{2}$, sobre a quantidade de ácido ascórbico em repolho, relatando que os níveis desta vitamina não foram afetados durante 5 a 10 dias, com 10 a 20\% de $\mathrm{CO}_{2}$. A perda de ácido ascórbico ocorreu quando se incrementou os níveis de $\mathrm{CO}_{2}$ para 30 a $40 \%$.

Em outra pesquisa sobre a quantidade de vitamina existente em hortaliças, Kurki (1979) determinou os efeitos da atmosfera controlada e refrigeração sobre o ácido ascórbico e vitamina A de um cultivar de alho, desenvolvido na Finlândia. Depois de 4 meses, a quantidade de ácido ascórbico dos alhos armazenados sob atmosfera controlada e refrigeração, 20,2 e 24,1 $\mathrm{mg} / 100 \mathrm{~g}$, respectivamente, apresentou poucas diferenças.

Nas frutas e hortaliças armazenadas em atmosfera controlada, os minerais se encontram concentrados, devido a perda de umidade (Zagory \& Kader, 1989). 
Segundo Klein (1987), a maioria das frutas e hortaliças são armazenadas sob refrigeração, acima do ponto de congelamento, para retardar os efeitos da respiração e transpiração. Para evitar também a desidratação e quebra dos produtos, devem ser controladas, tanto a temperatura quanto a umidade. Depois de 72 horas de armazenamento, sob temperatura de refrigeração, brócolis umidificados conservaram $75 \%$ do ácido ascórbico, enquanto que nos não umidificados houve retenção de 55\% desta vitamina (Barth et al., 1990). 


\section{MATERIAL E MÉTODOS}

\subsection{Matérias-primas}

O cultivar de cenoura (Daucus carota L.) utilizado foi "Nantes", colhido aos 120 dias. As amostras foram coletadas ao acaso no município de Piedade, SP.

O cultivar de pimentão (Capsicum annuum L.) utilizado foi "Magali", colhido aos 120 dias. Os cultivares de vagem (Phaseolus sp) e batata (Solanum tuberosum L.) utilizados foram "Macarrão" e "Monalisa", respectivamente. As amostras foram procedentes do CEASA do município de Piracicaba, SP.

\subsection{Processamento da cenoura}

As cenouras foram colhidas, selecionas e para a remoção do calor de campo e calor vital, foram acondicionadas em caixas de isopor, com medidas internas de $38 \mathrm{~cm} \times 29 \mathrm{~cm} \times 33,5 \mathrm{~cm}$, contendo gelo em camadas alternadas na proporção de 1:2 (gelo:cenoura) para serem transportadas para a Planta de Processamento de Alimentos da ESALQ-USP.

A higiene do processo foi assegurada através dos procedimentos estabelecidos pelas boas práticas de fabricação. Os utensílios foram sanificados com hipoclorito de sódio, $200 \mathrm{mg} \mathrm{L}^{-1}$ de cloro livre, e o pH foi ajustado para 7,0 . 
As cenouras foram lavadas em água corrente da rede pública, aparadas e descascadas com facas afiadas de aço inoxidável e imersas em água refrigerada, sendo a temperatura mantida $a \pm 7^{\circ} \mathrm{C}$.

Utilizando-se um processador, tipo picador de legumes, as cenouras foram cortadas em cubos $(1,0 \times 0,9 \mathrm{~cm})$ e para a sua sanificação, foram imersas por 15 min em água refrigerada a $\pm 7^{\circ} \mathrm{C}$ tratada com $100 \mathrm{mg} \mathrm{L}^{-1}$ de cloro livre e pH ajustado para 7,0. A seguir, foram centrifugadas a 550-900 G, por 5 min.

O produto foi acondicionado, manualmente, em sacos plásticos de filme multicamada laminado, do tipo BOPP/PEBD (polipropileno biorientado/polietileno de baixa densidade), fabricados pela ITAP Flexíveis S.A. cedidos pela Empresa Da Roça (Mogi das Cruzes, SP) apresentando as dimensões de $28 \mathrm{~cm}$ de comprimento por $24,5 \mathrm{~cm}$ de largura, espessura total de $70 \mu \mathrm{m}$ (parcial de 22/46 $\mu \mathrm{m}$ ) e permeabilidade ao $\mathrm{O}_{2}$ de $1688 \mathrm{~cm}^{3} / \mathrm{m}^{2} / \mathrm{dia}$ e ao $\mathrm{CO}_{2}$ de $6771 \mathrm{~cm}^{3} / \mathrm{m}^{2} /$ dia.

Os sacos contendo $400 \mathrm{~g}$ de cenoura picada em cubos foram fechados em seladora AP-500 da marca Tec Maq e caracterizados como amostras embaladas sob ar atmosférico. O embalamento das amostras a vácuo foi feito por 20 seg à pressão de $580 \mathrm{mmHg}$, e o embalamento com atmosfera modificada (AM) foi feito por 2 seg através da injeção de gases nas proporções de $2 \%$ de $\mathrm{O}_{2}, 10 \%$ de $\mathrm{CO}_{2}$ e $88 \%$ de $\mathrm{N}_{2}$ (mistura comercial Conservare 84 da marca White Martins). Os produtos foram armazenados a $1^{\circ} \mathrm{C} \pm 1^{\circ} \mathrm{C}$ durante 21 dias.

O processamento da cenoura foi conduzido conforme o fluxograma apresentado abaixo (Figura 1). 


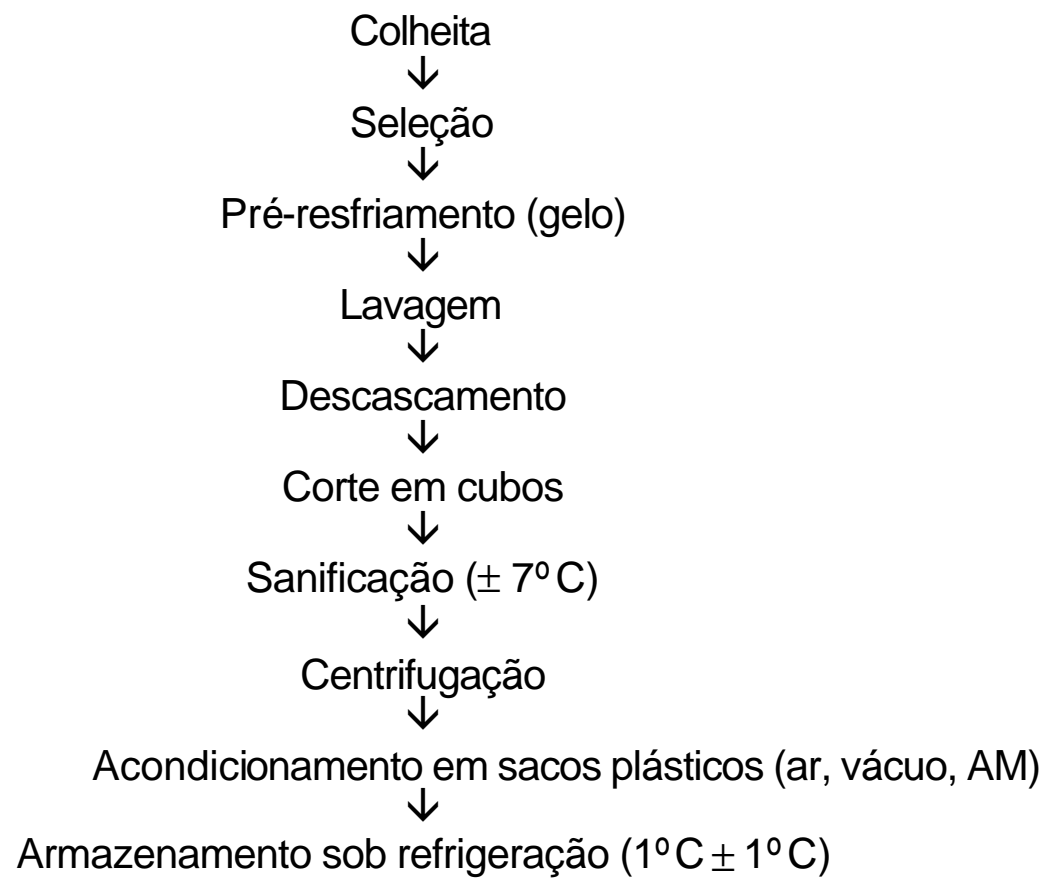

Figura 1 - Fluxograma de obtenção da cenoura minimamente processada.

\subsection{Processamento do pimentão}

Os pimentões provenientes do CEASA foram transportados, pela manhã, em caixas plásticas para a Planta de Processamento de Alimentos da ESALQUSP. Utilizando higiene adequada e utensílios devidamente sanificados com hipoclorito de sódio, com $200 \mathrm{mg} \mathrm{L}^{-1}$ de cloro livre, e pH ajustado para 7,0, os pimentões foram lavados em água corrente, cortados com facas afiadas de aço inoxidável para a retirada do pedúnculo e sementes, e imersos em água refrigerada $\left( \pm 7^{\circ} \mathrm{C}\right)$.

Os pimentões foram fatiados no sentido transversal, em rodelas de aproximadamente $2 \mathrm{~mm}$ de espessura, que foram sanificadas por imersão durante $15 \mathrm{~min}$ em água refrigerada $\mathrm{a} \pm 7^{\circ} \mathrm{C}$ com $100 \mathrm{mg} \mathrm{L}^{-1}$ de cloro livre, e $\mathrm{pH}$ ajustado para 7,0. A seguir, foram centrifugadas a 550-900 G, por 5 min e acondicionadas, manualmente, em sacos plásticos. 
Os sacos tipo BOPP/PEBD contendo $250 \mathrm{~g}$ de pimentão fatiado em rodelas foram fechados sob ar atmosférico, vácuo (15 seg e pressão de $540 \mathrm{mmHg}$ na seladora) e atmosfera modificada (3 seg com $2 \%$ de $\mathrm{O}_{2}, 10 \%$ de $\mathrm{CO}_{2}$ e $88 \%$ de $\mathrm{N}_{2}$ ). Os produtos foram armazenados a $1^{\circ} \mathrm{C} \pm 1^{\circ} \mathrm{C}$ durante 21 dias.

O processamento do pimentão foi conduzido conforme o fluxograma apresentado abaixo (Figura 2).

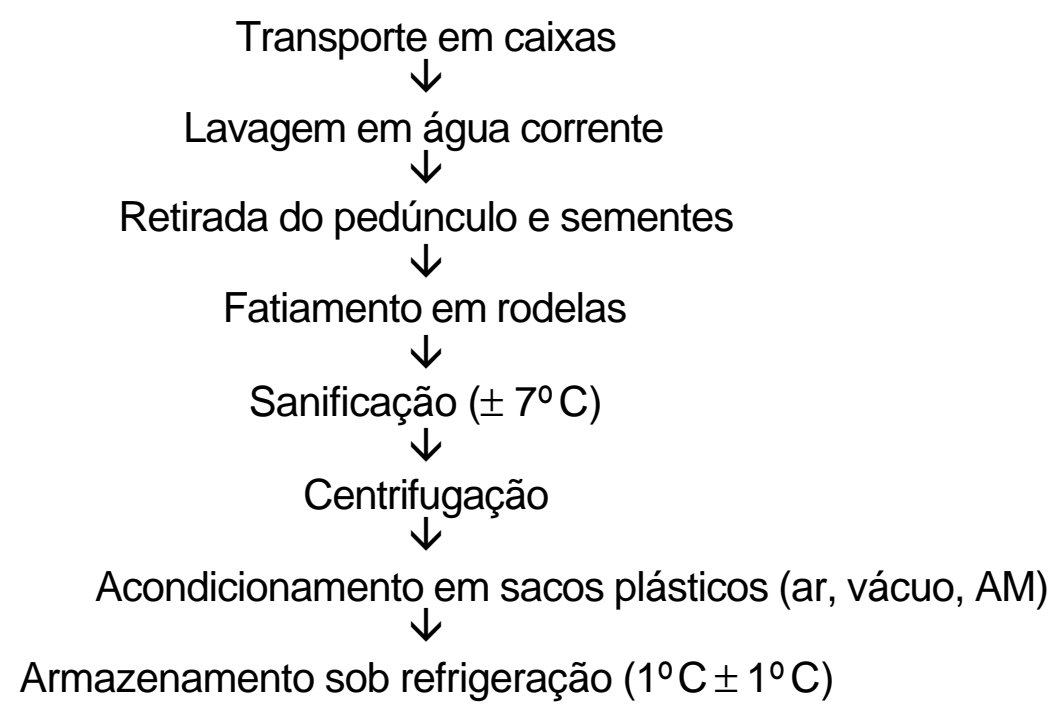

Figura 2 - Fluxograma de obtenção do pimentão minimamente processado.

\subsection{Processamento da salada mista (vagem e batata)}

As vagens e batatas provenientes do CEASA foram transportadas, pela manhã, em caixas plásticas para a Planta de Processamento de Alimentos da ESALQUSP. Utilizando higiene adequada e utensílios devidamente sanificados com hipoclorito de sódio, com $200 \mathrm{mg} \mathrm{L}^{-1}$ de cloro livre, e pH ajustado para 7,0, as hortaliças foram lavadas em água corrente, as vagens tiveram suas 
extremidades cortadas e as batatas foram descascadas com facas afiadas de aço inoxidável e, separadamente, imersas em água refrigerada $\left( \pm 7^{\circ} \mathrm{C}\right)$.

As vagens foram fatiadas no sentido transversal, manualmente, em pedaços de aproximadamente $1 \mathrm{~cm}$ de espessura. As batatas foram cortadas e picadas em cubos $(1,0 \times 0,9 \mathrm{~cm})$ utilizando-se um processador, tipo picador de legumes e colocadas em água fria $\left( \pm 7^{\circ} \mathrm{C}\right)$. As duas hortaliças foram sanificadas por imersão durante 15 min em água refrigerada a $\pm 7^{\circ} \mathrm{C}$ com $100 \mathrm{mg} \mathrm{L}^{-1}$ de cloro livre, e pH ajustado para 7,0.

Os cubos de batata, após a sanificação, passaram por um tratamento químico para a inativação da polifenoloxidase, utilizando-se ácido ascórbico 0,1\% e metabissulfito de sódio 0,05\% em água esterilizada, conforme Almeida (1991). Posteriormente, as fatias de vagem e os cubos de batata foram centrifugados a 550-900 G, por 5 min e acondicionados, manualmente, em sacos plásticos do tipo BOPP/PEBD.

As embalagens contendo $300 \mathrm{~g}$ de salada mista foram fechadas sob ar atmosférico, vácuo (15 seg e pressão de $540 \mathrm{mmHg}$ ) e atmosfera modificada (4 seg com $2 \%$ de $\mathrm{O}_{2}, 10 \%$ de $\mathrm{CO}_{2}$ e $88 \%$ de $\mathrm{N}_{2}$ ). Os produtos foram armazenados a $1^{\circ} \mathrm{C} \pm 1^{\circ} \mathrm{C}$ durante 21 dias.

O processamento da salada mista foi conduzido conforme o fluxograma apresentado abaixo (Figura 3). 


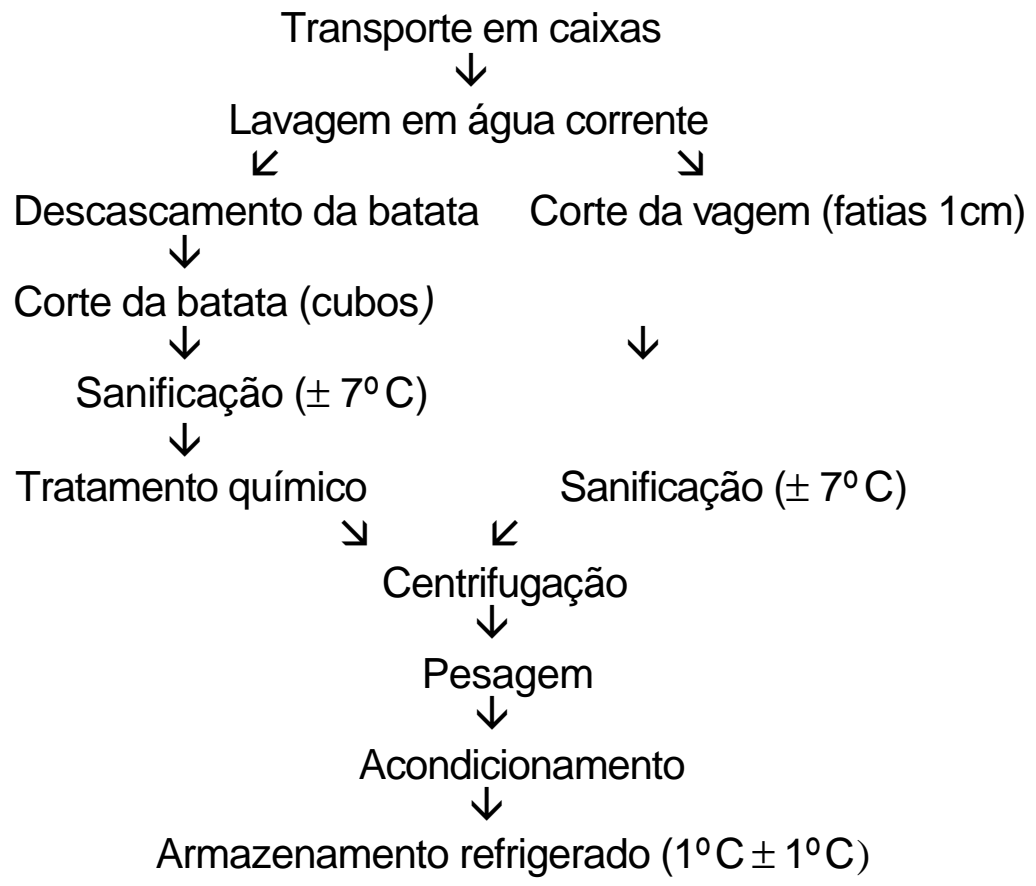

Figura 3 - Fluxograma de obtenção da salada mista minimamente processada.

\subsection{Delineamento experimental}

As amostras de cenoura, pimentão e salada mista minimamente processados foram avaliadas segundo delineamento inteiramente casualizado, usando esquema fatorial $3 \times 4$, com duas repetições. Os três tratamentos foram ar, vácuo e atmosfera modificada e os quatro períodos de armazenamento foram de 1, 7, 14 e 21 dias. Os resultados foram submetidos à análise de variância através do programa SANEST (Zonta et al., 1986). As médias foram comparadas entre si pelo teste de Tukey, adotando-se o nível de significância de $5 \%$.

\subsection{Análises físico-químicas}

3.6.1 Umidade: realizada em estufa através da perda de peso da amostra aquecida a $105^{\circ} \mathrm{C} \pm 1^{\circ} \mathrm{C}$, até peso constante, de acordo com AOAC (1995). 
3.6.2 Proteína: realizada mediante a determinação do nitrogênio total, pelo método de Kjeldahl, e conversão em proteína multiplicando o valor obtido pelo fator 6,25, conforme Sarruge \& Haag (1974).

3.6.3 Lipídeos: foram determinados através do método Soxhlet, conforme AOAC (1995).

3.6.4 Cinza: foi feita a incineração da matéria orgânica e posteriormente as amostras, para total calcinação, foram levadas àmufla a $550^{\circ} \mathrm{C}$, segundo $\mathrm{AOAC}$ (1995).

3.6.5 Acidez titulável: medida por titulação da amostra filtrada com hidróxido de sódio $0,01 \mathrm{~N}$. Os resultados foram expressos em \% de ácido cítrico e málico (AOAC, 1995).

3.6.6 pH: determinado, na amostra triturada, utilizando-se potenciômetro digital (AOAC, 1995).

3.6.7 Vitamina C: determinada pela titulação com Reativo de Tillmans (2,6 diclorofenol-indofenol), até obtenção de coloração ligeiramente rosada e estável por 15 seg. Os resultados foram expressos em mg de ácido ascórbico por $100 \mathrm{~g}$ de amostra (Pregnolatto \& Pregnolatto, 1985).

3.6.8 Minerais: determinados segundo o método de Sarruge \& Haag (1974). A quantificação do cálcio, manganês, fósforo, ferro, cobre, magnésio e zinco foi realizada por espectrofotometria de absorção atômica e a do potássio por fotometria de chama.

3.6.9 $\beta$-caroteno: a determinação das concentrações de $\beta$-caroteno foi baseada no procedimento de Rodriguez-Amaya et al. (1976). Esse 
procedimento constitui-se, basicamente, de uma extração seguida de cromatografia em coluna para separação do pigmento e leitura em espectrofotômetro. Os resultados foram expressos em miligramas de $\beta$ caroteno por $100 \mathrm{~g}$ de amostra.

3.7 Análises microbiológicas: as análises microbiológicas foram feitas para contagem de coliformes totais e fecais, de anaeróbios mesófilos, de salmonela e psicrotróficos. Foram realizadas no $1^{\circ}, 7^{\circ}, 14^{\circ}$ e $21^{\circ}$ dias de armazenamento e foram conduzidas em triplicata para cada tratamento.

3.7.1 Contagem total de anaeróbios mesófilos e psicrotróficos: para a contagem total de anaeróbios mésofilos, as amostras foram inoculadas em Plate Count Agar (PCA) e incubadas a $35^{\circ} \mathrm{C}$, por $48 \mathrm{~h}$, em anaerobiose. Para Psicrotróficos, a incubação foi feita a $7^{\circ} \mathrm{C}$ durante 10 dias, segundo Vanderzant \& Splittstoesser (1992).

3.7.2 Contagem de coliformes totais e fecais: realizada pela metodologia Simplate, que utiliza kits compostos de placas descartáveis contendo 84 cavidades, fabricados pelos Laboratórios Idexx. As placas foram incubadas a $35^{\circ} \mathrm{C}$, por $24 \mathrm{~h}$, para posterior leitura dos resultados.

3.7.3 Análise de Salmonella: utilizou-se o kit "Oxoid Salmonella Rapid Test" FT201A, fabricado por Unipath Ltda. Esta metodologia foi adotada pela Association Française de Normalisation (AFNOR), em 1991, e teve sua recomendação de adoção em primeira ação pela Association of Official Analythical Chemists/Food and Drugs Administration (AOAC/FDA), em 1993 (Silva, 1997). Os frascos foram incubados em estufa termoestatizada, a $35 \pm$ $2^{0} \mathrm{C}$ por 24h. Decorrido o tempo de incubação, fez-se o preparo dos kits, compostos, cada um, de um recipiente contendo dois tubos, A e B. Inoculou-se $1 \mathrm{~mL}$ da amostra pré-enriquecida e incubou-se o kit a $41^{\circ} \mathrm{C}$ por $24 \mathrm{~h}$. Após a 
incubação, foi feita a leitura e interpretação dos resultados, de acordo com as colorações apresentadas nos tubos A e B.

3.8 Análise sensorial: a avaliação das amostras foi realizada quanto à cor, aroma, sabor, textura e avaliação global, utilizando o Teste de Aceitabilidade em escala hedônica de 9 pontos ( $9=$ gostei extremamente, $5=$ não gostei nem desgostei e 1=desgostei extremamente) (Poste et al., 1991). As amostras para o Teste de Aceitabilidade foram apresentas ao provador em pratos de porcelana cobertos $\infty m$ filmes de polietileno numerados com algarismos de três dígitos. Para a avaliação do produto embalado, utilizou-se o Teste de Preferência (Poste et al., 1991), onde os provadores receberam amostras embaladas com os tratamentos a vácuo e atmosfera modificada, descrevendo sua preferência. Os testes foram realizados em cabines individuais com iluminação de lâmpadas fluorescentes.

\subsubsection{Cenoura e pimentão}

Foram recrutados 25 provadores não treinados para a avaliação das amostras de cenoura e pimentão, com idade entre 18 e 50 anos (Poste et al., 1991).

As cenouras minimamente processadas foram avaliadas segundo delineamento inteiramente casualizado com três tratamentos (ar, vácuo e atmosfera modificada), quatro períodos de armazenamento (1, 7, 14 e 21 dias) e 25 repetições, constituindo cada provador uma repetição. Os pimentões minimamente processados foram avaliados segundo delineamento inteiramente casualizado com quatro tratamentos (ar, vácuo, atmosfera modificada e amostra in natura), quatro períodos de armazenamento (1, 7, 14 e 21 dias) e 25 repetições, constituindo cada provador uma repetição. Os resultados foram submetidos à análise de variância através do programa SANEST (Zonta et al., 1986). As médias foram comparadas entre si pelo teste de Tukey, a $5 \%$ de probabilidade. 


\subsubsection{Salada mista}

Participaram 10 provadores fixos com idade entre 25 e 50 anos. Parte das amostras foram cozidas em $2 \%$ de $\mathrm{NaCl}$ e submetidas à avaliação global, aroma, sabor e textura. As amostras cruas foram avaliadas quanto àcor.

Os produtos foram avaliados segundo delineamento inteiramente casualizado com três tratamentos (ar, vácuo e atmosfera modificada), quatro períodos de armazenamento (1, 7, 14 e 21 dias) e 10 repetições, constituindo cada provador uma repetição. Os resultados foram submetidos à análise de variância através do programa SANEST (Zonta et al., 1986). As médias foram comparadas entre si pelo teste de Tukey, a $5 \%$ de probabilidade. 


\section{RESULTADOS E DISCUSSÃO}

\subsection{Análises físico-químicas}

\subsubsection{Composição centesimal}

A composição química centesimal de um alimento expressa o seu potencial em nutrientes, sendo esses dados importantes para a indústria de alimentos. Na literatura, são escassas as informações sobre a composição centesimal de hortaliças minimamente processadas.

Nesta pesquisa, os valores de umidade, lipídeos, proteína e cinza, apresentaram diferença estatística, porém, permaneceram estáveis durante o período de armazenamento de 7,14 e 21 dias, a $1^{\circ} \mathrm{C} \pm 1^{\circ} \mathrm{C}$ para os três produtos analisados, œnoura, pimentão e salada mista minimamente processados, bem como nos 3 tipos de tratamentos testados.

Os teores médios de umidade da cenoura, pimentão e da salada mista variaram de 89,59 a 90,89 g/100g, 94,0 a 94,7 g/100g e 87,3 a 88,6 g/100, respectivamente (Tabela 3 e Figura 4). Esses valores estão em conformidade com os dados divulgados pela Embrapa na Tabela de composição nutricional das hortaliças in natura, 92,2 g/100g para a cenoura, 92,8 g/100g para o pimentão, 83,3 g/100g para a batata e 90,1 g/100g para a vagem (Luengo et al., 2000). 
Tabela 3. Umidade em cenoura, pimentão e salada mista minimamente processados, embalados sob ar atmosférico, vácuo e atmosfera modificada, armazenado sob refrigeração a $1^{\circ} \mathrm{C} \pm 1^{\circ} \mathrm{C}$.

\begin{tabular}{|c|c|c|c|c|c|c|}
\hline \multirow{3}{*}{ Produtos } & \multirow{3}{*}{ Tratamentos } & \multicolumn{4}{|c|}{ Umidade $(\mathrm{g} / 100 \mathrm{~g})$} & \multirow{3}{*}{ Médias } \\
\hline & & \multicolumn{4}{|c|}{ Dias } & \\
\hline & & 1 & 7 & 14 & 21 & \\
\hline \multirow{4}{*}{ Cenoura } & $\mathrm{Ar}$ & 89,59 & 89,89 & 90,08 & 90,78 & $90,08 \mathrm{a}$ \\
\hline & Vácuo & 89,80 & 90,02 & 90,57 & 90,89 & 90,32 a \\
\hline & Atm & 89,67 & 90,03 & 90,50 & 90,65 & $90,21 \mathrm{a}$ \\
\hline & Médias & $89,69 \mathrm{~B}$ & $90,23 \mathrm{AB}$ & $90,38 \mathrm{~A}$ & $90,77 \mathrm{~A}$ & \\
\hline \multirow{4}{*}{ Pimentão } & $\mathrm{Ar}$ & 94,07 & 94,00 & 94,28 & 94,29 & $94,16 \quad b$ \\
\hline & Vácuo & 94,08 & 94,58 & 94,70 & 94,57 & 94,48 a \\
\hline & Atm & 94,23 & 94,32 & 94,36 & 94,52 & $94,35 a b$ \\
\hline & Médias & $94,13 \mathrm{~A}$ & $94,30 \mathrm{~A}$ & $94,46 \mathrm{~A}$ & $94,46 \mathrm{~A}$ & \\
\hline \multirow{4}{*}{$\begin{array}{l}\text { Salada } \\
\text { mista }\end{array}$} & $\mathrm{Ar}$ & 87,70 & 88,09 & 88,00 & 88,57 & 88,09 a \\
\hline & Vácuo & 87,33 & 88,07 & 88,35 & 88,44 & $88,05 \mathrm{a}$ \\
\hline & Atm & 87,57 & 88,29 & 88,59 & 88,63 & 88,27 a \\
\hline & Médias & $87,53 \mathrm{~B}$ & $88,15 \mathrm{~A}$ & $88,31 \mathrm{~A}$ & $88,55 \mathrm{~A}$ & \\
\hline
\end{tabular}

Nota: Valores seguidos com a mesma letra maiúscula, dentro da mesma linha, e com a mesma letra minúscula, dentro da mesma subcoluna, não diferem entre si estatisticamente $(p<0,05)$. 

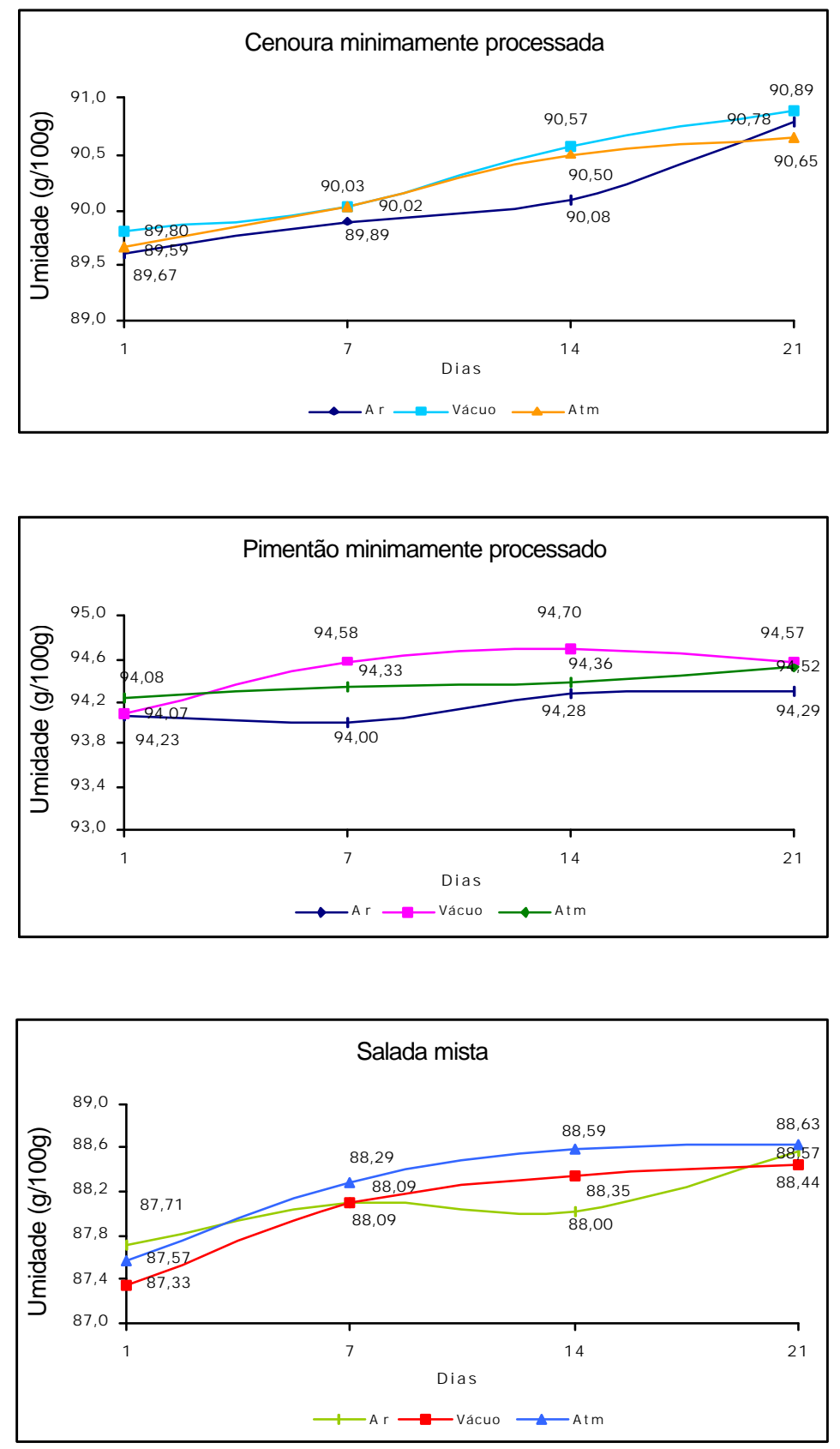

Figura 4 - Umidade em cenouras, pimentões e salada mista minimamente processados, embalados sob ar atmosférico, vácuo e atmosfera modificada, armazenados sob refrigeração a $1^{\circ} \mathrm{C} \pm 1^{\circ} \mathrm{C}$. 
Os teores de lipídeos variaram de 0,08 a 0,13 g/100g para a cenoura, 0,07 a 0,09 g/100g para o pimentão e 0,04 a 0,06 g/100g para a salada mista minimamente processados (Tabela 4 e Figura 5). De acordo com Franco (1999), os teores deste componente para cenoura, pimentão, batata e vagem in natura são 0,07 g/100g, 0,20 g/100g, 0,1 $g / 100 \mathrm{~g}$ e $\quad 0,20$ g/100g, respectivamente.

Tabela 4. Lipídeos em cenoura, pimentão e salada mista minimamente processados, embalados sob ar atmosférico, vácuo e atmosfera modificada, armazenadas sob refrigeração a $1^{\circ} \mathrm{C} \pm 1^{\circ} \mathrm{C}$.

\begin{tabular}{|c|c|c|c|c|c|c|}
\hline \multirow{3}{*}{ Produtos } & \multirow{3}{*}{ Tratamentos } & \multicolumn{4}{|c|}{ Lipídeos (g/100g) } & \multirow{3}{*}{ Médias } \\
\hline & & \multicolumn{4}{|c|}{ Dias } & \\
\hline & & 1 & 7 & 14 & 21 & \\
\hline \multirow{4}{*}{ Cenoura } & $\mathrm{Ar}$ & 0,101 & 0,104 & 0,119 & 0,109 & $0,108 \mathrm{a}$ \\
\hline & Vácuo & 0,083 & 0,120 & 0,135 & 0,118 & $0,114 \mathrm{a}$ \\
\hline & Atm & 0,089 & 0,110 & 0,128 & 0,122 & $0,112 \mathrm{a}$ \\
\hline & Médias & $0,091 \mathrm{~B}$ & $0,111 \mathrm{AB}$ & $0,127 \mathrm{~A}$ & $0,116 \mathrm{~A}$ & \\
\hline \multirow{4}{*}{ Pimentão } & $\mathrm{Ar}$ & 0,075 & 0,083 & 0,074 & 0,091 & $0,081 \mathrm{a}$ \\
\hline & Vácuo & 0,074 & 0,077 & 0,075 & 0,093 & $0,080 \mathrm{a}$ \\
\hline & Atm & 0,069 & 0,072 & 0,066 & 0,085 & $0,073 \quad b$ \\
\hline & Médias & $0,073 \mathrm{~B}$ & $0,077 \mathrm{~B}$ & $0,071 \mathrm{~B}$ & $0,090 \mathrm{~A}$ & \\
\hline \multirow{4}{*}{$\begin{array}{l}\text { Salada } \\
\text { mista }\end{array}$} & $\operatorname{Ar}$ & 0,046 & 0,045 & 0,066 & 0,044 & $0,050 \quad b$ \\
\hline & Vácuo & 0,055 & 0,05 & 0,065 & 0,047 & $0,054 \mathrm{a}$ \\
\hline & Atm & 0,060 & 0,054 & 0,061 & 0,048 & $0,056 \mathrm{a}$ \\
\hline & Médias & $0,054 \mathrm{~B}$ & $0,049 \mathrm{BC}$ & $0,064 \mathrm{~A}$ & $0,046 \mathrm{C}$ & \\
\hline
\end{tabular}

Nota: Valores seguidos com a mesma letra maiúscula, dentro da mesma linha, e com a mesma letra minúscula, dentro da mesma subcoluna, não diferem entre si estatisticamente $(p<0,05)$. 

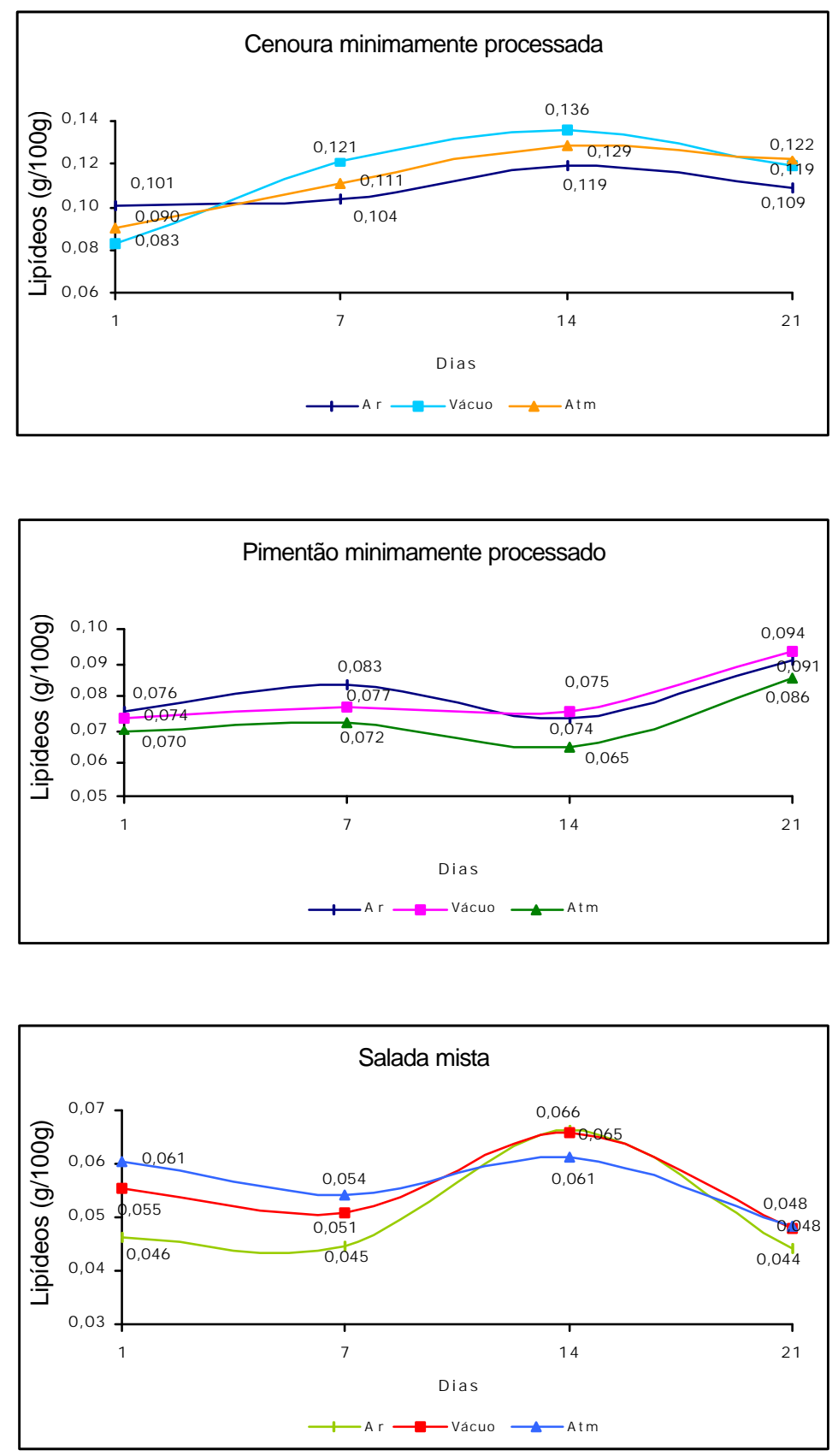

Figura 5 - Lipídeos em cenouras, pimentões e salada mista minimamente processados, embalados sob ar atmosférico, vácuo e atmosfera modificada, armazenados sob refrigeração a $1^{\circ} \mathrm{C} \pm 1^{\circ} \mathrm{C}$. 
Os valores encontrados para proteína foram de 0,78 a 0,91 $\mathrm{g} / 100 \mathrm{~g}$ para a cenoura, 0,59 a 0,69 g/100g para o pimentão e 1,77 a 2,00 g/100g para a salada mista (Tabela 5 e Figura 6), estando próximos aos citados na Tabela Brasileira de Composição de Alimentos (Universidade de São Paulo - USP, 2001), 1,0 g/100g para a cenoura, 0,77 g/100g para o pimentão e 2,3 g/100g para a vagem.

Tabela 5. Proteína em cenoura, pimentão e salada mista minimamente processados, embalados sob ar atmosférico, vácuo e atmosfera modificada, armazenadas sob refrigeração a $1^{\circ} \mathrm{C} \pm 1^{\circ} \mathrm{C}$.

\begin{tabular}{|c|c|c|c|c|c|c|}
\hline \multirow{3}{*}{ Produtos } & \multirow{3}{*}{ Tratamentos } & \multicolumn{4}{|c|}{ Proteína $(\mathrm{g} / 100 \mathrm{~g})$} & \multirow{3}{*}{ Médias } \\
\hline & & \multicolumn{4}{|c|}{ Dias } & \\
\hline & & 1 & 7 & 14 & 21 & \\
\hline \multirow{4}{*}{ Cenoura } & $\mathrm{Ar}$ & 0,910 & 0,905 & 0,869 & 0,833 & $0,879 \mathrm{a}$ \\
\hline & Vácuo & 0,788 & 0,782 & 0,815 & 0,817 & $0,800 \quad b$ \\
\hline & Atm & 0,885 & 0,801 & 0,787 & 0,873 & $0,836 a b$ \\
\hline & Médias & $0,861 \mathrm{~A}$ & $0,829 \mathrm{~A}$ & $0,824 \mathrm{~A}$ & $0,841 \mathrm{~A}$ & \\
\hline \multirow{4}{*}{ Pimentão } & $\mathrm{Ar}$ & 0,642 & 0,64 & 0,652 & 0,672 & $0,651 \mathrm{a}$ \\
\hline & Vácuo & 0,692 & 0,60 & 0,618 & 0,628 & $0,635 \mathrm{a}$ \\
\hline & Atm & 0,650 & 0,635 & 0,619 & 0,595 & $0,625 \mathrm{a}$ \\
\hline & Médias & $0,661 \mathrm{~A}$ & $0,625 \mathrm{~A}$ & $0,629 \mathrm{~A}$ & $0,631 \mathrm{~A}$ & \\
\hline \multirow{4}{*}{$\begin{array}{l}\text { Salada } \\
\text { mista }\end{array}$} & $\operatorname{Ar}$ & 1,962 & 1,834 & 1,815 & 1,841 & $1,863 \mathrm{a}$ \\
\hline & Vácuo & 2,000 & 1,932 & 1,789 & 1,809 & $1,883 \mathrm{a}$ \\
\hline & Atm & 1,926 & 1,774 & 1,836 & 1,832 & $1,842 \mathrm{a}$ \\
\hline & Médias & $1,963 \mathrm{~A}$ & $1,847 \mathrm{~B}$ & $1,813 \mathrm{~B}$ & $1,827 \mathrm{~B}$ & \\
\hline
\end{tabular}

Nota: Valores seguidos com a mesma letra maiúscula, dentro da mesma linha, e com a mesma letra minúscula, dentro da mesma subcoluna, não diferem entre si estatisticamente $(p<0,05)$. 

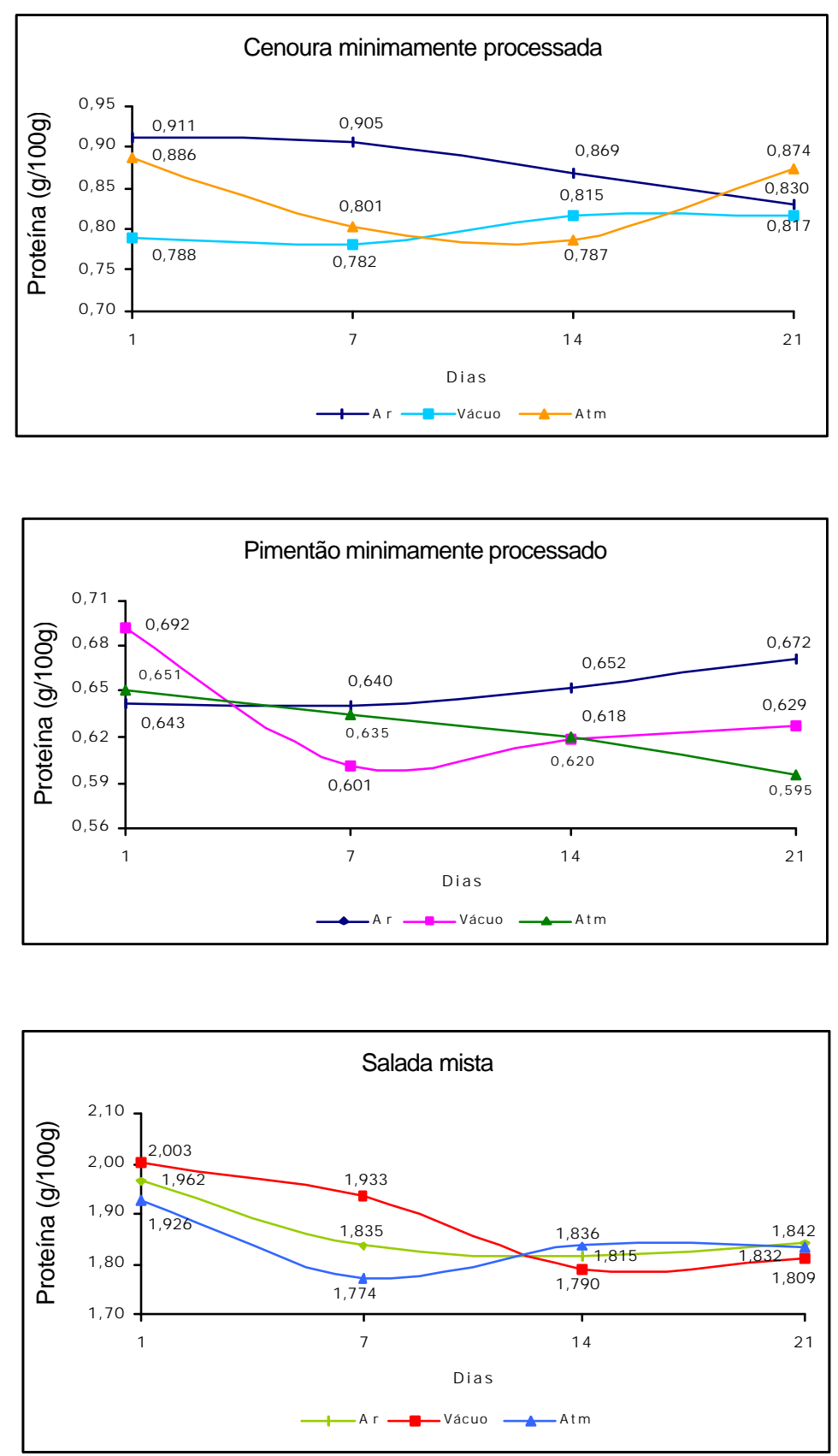

Figura 6 - Proteína em cenouras, pimentões e salada mista minimamente processados, embalados sob ar atmosférico, vácuo e atmosfera modificada, armazenados sob refrigeração a $1^{\circ} \mathrm{C} \pm 1^{\circ} \mathrm{C}$. 
Os teores de cinza variaram de 0,68 a 0,72 $\mathrm{g} / 100 \mathrm{~g}$ para a cenoura, 0,23 a 0,29 g/100g para o pimentão e 0,56 a 0,60 para a salada mista (Tabela 6 e Figura 7), estando em conformidade com a Tabela Brasileira de Composição de Alimentos (USP, 2001), onde pode-se observar para hortaliças in natura valores de $0,81 \mathrm{~g} / 100 \mathrm{~g}$ para a cenoura, 0,38 para o pimentão e $0,79 \mathrm{~g} / 100 \mathrm{~g}$ para a vagem.

Tabela 6. Cinza em cenoura, pimentão e salada mista minimamente processados, embalados sob ar atmosférico, vácuo e atmosfera modificada, armazenadas sob refrigeração a $1^{\circ} \mathrm{C} \pm 1^{\circ} \mathrm{C}$.

\begin{tabular}{|c|c|c|c|c|c|c|}
\hline \multirow{3}{*}{ Produtos } & \multirow{3}{*}{ Tratamentos } & \multicolumn{4}{|c|}{ Cinza $(g / 100 g)$} & \multirow{3}{*}{ Médias } \\
\hline & & \multicolumn{4}{|c|}{ Dias } & \\
\hline & & 1 & 7 & 14 & 21 & \\
\hline \multirow{4}{*}{ Cenoura } & $\mathrm{Ar}$ & 0,712 & 0,71 & 0,719 & 0,684 & $0,706 \mathrm{a}$ \\
\hline & Vácuo & 0,698 & 0,717 & 0,713 & 0,688 & $0,704 \mathrm{a}$ \\
\hline & Atm & 0,717 & 0,695 & 0,709 & 0,71 & $0,707 \mathrm{a}$ \\
\hline & Médias & $0,709 \mathrm{~A}$ & $0,707 \mathrm{~A}$ & $0,713 \mathrm{~A}$ & $0,694 \mathrm{~A}$ & \\
\hline \multirow{4}{*}{ Pimentão } & $\mathrm{Ar}$ & 0,274 & 0,286 & 0,262 & 0,271 & $0,273 \mathrm{a}$ \\
\hline & Vácuo & 0,273 & 0,260 & 0,234 & 0,248 & $0,253 \quad b$ \\
\hline & Atm & 0,262 & 0,279 & 0,268 & 0,251 & $0,265 a$ \\
\hline & Médias & $0,269 \mathrm{~A}$ & $0,275 \mathrm{~A}$ & $0,254 \mathrm{~B}$ & $0,255 \mathrm{~B}$ & \\
\hline \multirow{4}{*}{$\begin{array}{l}\text { Salada } \\
\text { mista }\end{array}$} & $\mathrm{Ar}$ & 0,575 & 0,58 & 0,578 & 0,559 & $0,573 a$ \\
\hline & Vácuo & 0,597 & 0,568 & 0,570 & 0,558 & $0,573 a$ \\
\hline & Atm & 0,582 & 0,573 & 0,558 & 0,557 & $0,567 \mathrm{a}$ \\
\hline & Médias & $0,585 \mathrm{~A}$ & $0,574 \mathrm{AB}$ & $0,569 \mathrm{BC}$ & $0,558 \mathrm{C}$ & \\
\hline
\end{tabular}

Nota: Valores seguidos com a mesma letra maiúscula, dentro da mesma linha, e com a mesma letra minúscula, dentro da mesma subcoluna, não diferem entre si estatisticamente $(p<0,05)$. 

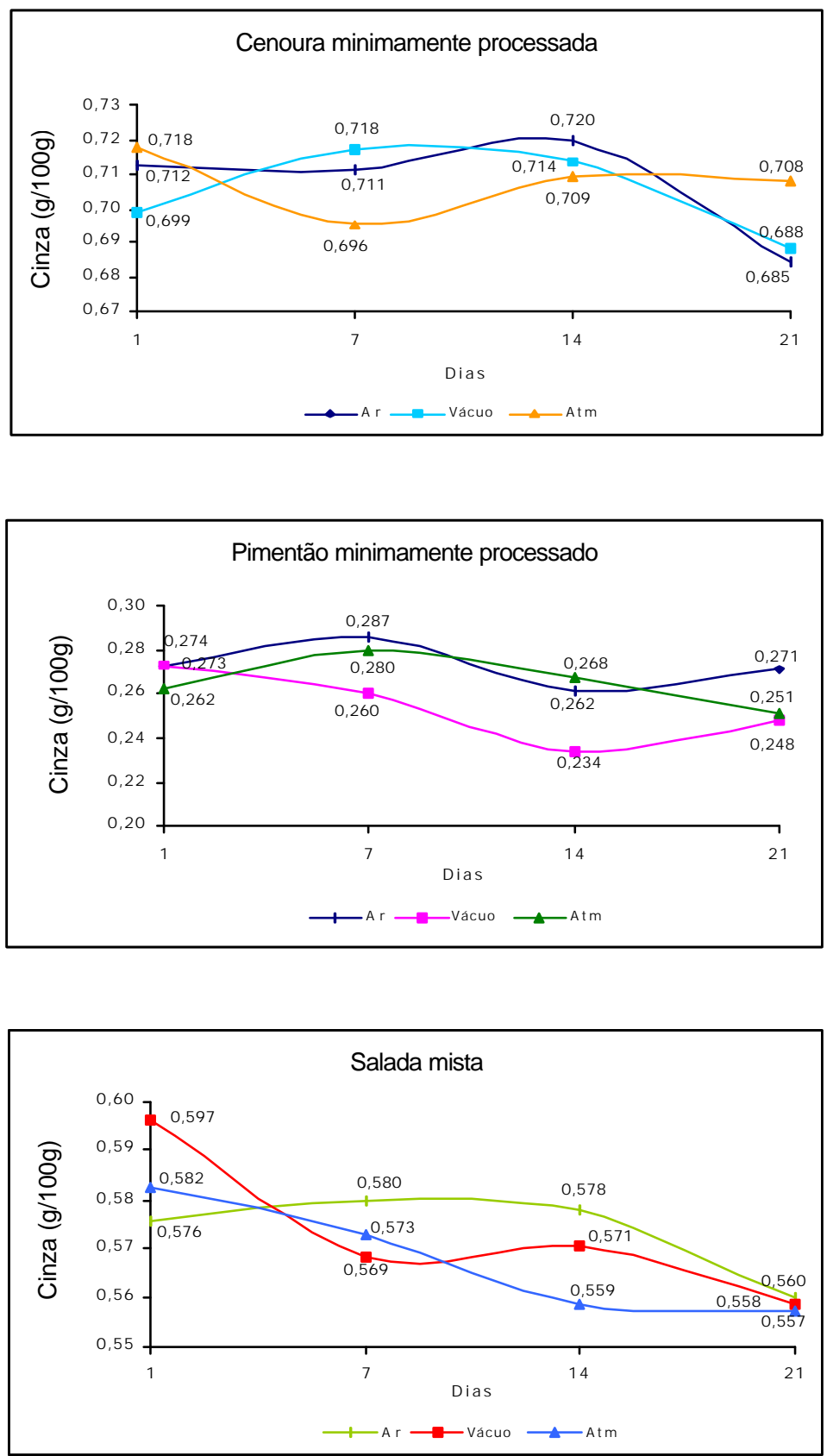

Figura 7 - Cinza em cenouras, pimentões e salada mista minimamente processados, embalados sob ar atmosférico, vácuo e atmosfera modificada, armazenados sob refrigeração a $1^{\circ} \mathrm{C} \pm 1^{\circ} \mathrm{C}$. 


\subsubsection{Acidez titulável}

Os resultados médios de acidez titulável obtidos para cenoura, pimentão e salada mista de batata e vagem minimamente processados, foram expressos em percentagem de ácidos málico e cítrico.

A Tabela 7 e a Figura 8 apresentam os dados da variação da acidez em cenoura, pimentão e salada mista minimamente processados durante o período de armazenamento.

Tabela 7. Acidez titulável em cenoura, pimentão e salada mista minimamente processados, embalados sob ar atmosférico, vácuo e atmosfera modificada, armazenadas sob refrigeração a $1^{\circ} \mathrm{C} \pm 1^{\circ} \mathrm{C}$.

\begin{tabular}{|c|c|c|c|c|c|c|}
\hline \multirow{3}{*}{ Produtos } & \multirow{3}{*}{ Tratamentos } & \multicolumn{4}{|c|}{ Acidez titulável (mg/100g) } & \multirow{3}{*}{ Médias } \\
\hline & & \multicolumn{4}{|c|}{ Dias } & \\
\hline & & 1 & 7 & 14 & 21 & \\
\hline \multirow{4}{*}{ Cenoura } & $\mathrm{Ar}$ & 0,069 & 0,058 & 0,061 & 0,058 & $0,062 \mathrm{a}$ \\
\hline & Vácuo & 0,061 & 0,058 & 0,069 & 0,056 & $0,061 \mathrm{a}$ \\
\hline & Atm & 0,066 & 0,058 & 0,072 & 0,061 & $0,064 \mathrm{a}$ \\
\hline & Médias & $0,065 \mathrm{AB}$ & $0,058 \mathrm{~B}$ & $0,067 \mathrm{~A}$ & $0,058 \mathrm{~B}$ & \\
\hline \multirow{4}{*}{ Pimentão } & $\mathrm{Ar}$ & 0,059 & 0,051 & 0,058 & 0,052 & $0,055 \mathrm{a}$ \\
\hline & Vácuo & 0,061 & 0,048 & 0,061 & 0,048 & $0,055 \mathrm{a}$ \\
\hline & Atm & 0,061 & 0,048 & 0,061 & 0,052 & $0,056 \mathrm{a}$ \\
\hline & Médias & $0,060 \mathrm{~A}$ & $0,049 \mathrm{~B}$ & $0,060 \mathrm{~A}$ & $0,051 \mathrm{~B}$ & \\
\hline \multirow{4}{*}{$\begin{array}{l}\text { Salada } \\
\text { mista }\end{array}$} & $\operatorname{Ar}$ & 0,083 & 0,074 & 0,069 & 0,077 & $0,076 \mathrm{a}$ \\
\hline & Vácuo & 0,078 & 0,074 & 0,067 & 0,080 & $0,075 a$ \\
\hline & Atm & 0,080 & 0,077 & 0,064 & 0,077 & $0,074 a$ \\
\hline & Médias & $0,080 \mathrm{~A}$ & $0,075 \mathrm{~A}$ & $0,067 \mathrm{~B}$ & $0,078 \mathrm{~A}$ & \\
\hline
\end{tabular}

Nota: Valores seguidos com a mesma letra maiúscula, dentro da mesma linha, e com a mesma letra minúscula, dentro da mesma subcoluna, não diferem entre si estatisticamente $(p<0,05)$. 

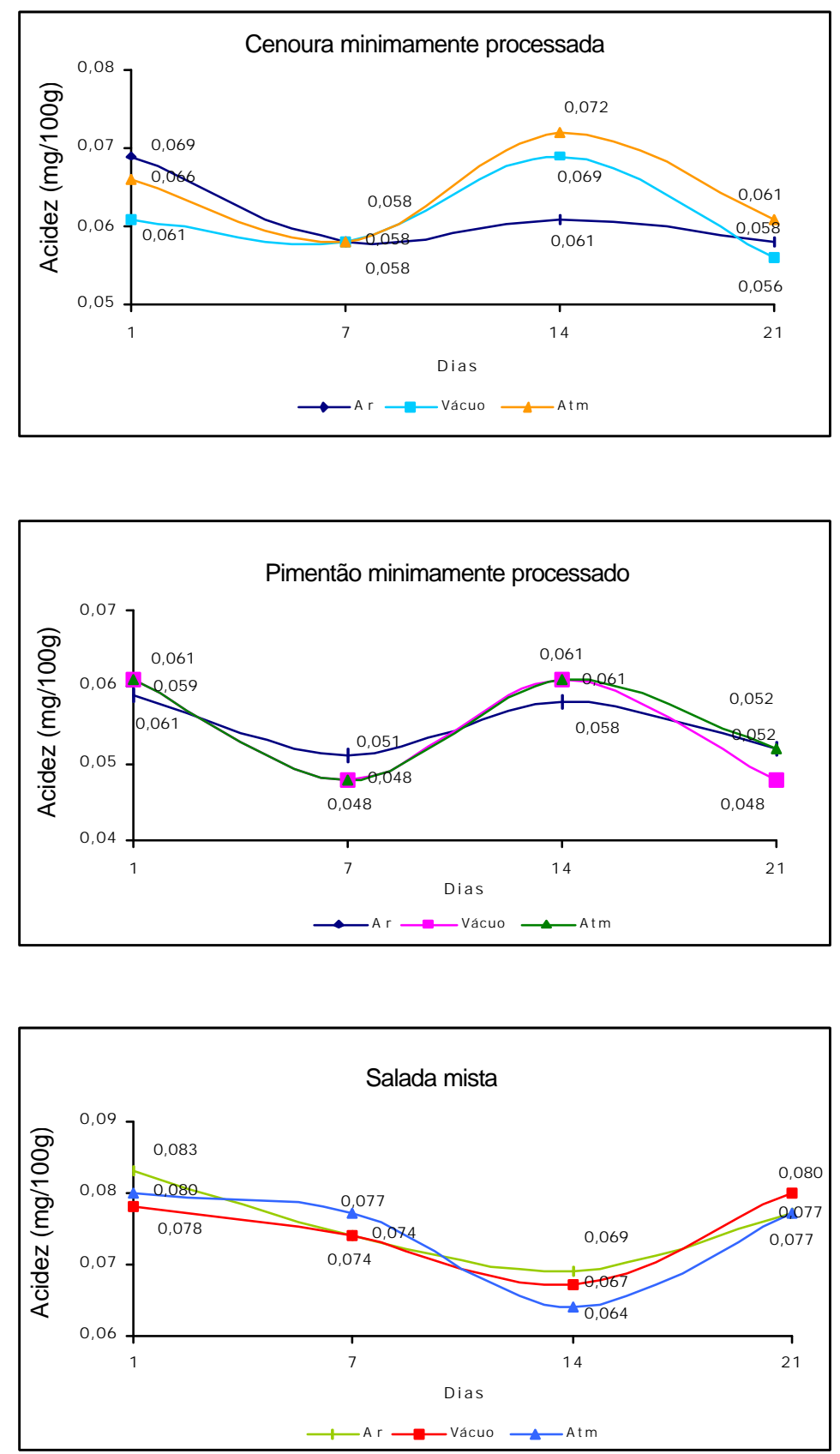

Figura 8 - Acidez titulável em cenouras, pimentões e salada mista minimamente processados, embalados sob ar atmosférico, vácuo e atmosfera modificada, armazenados sob refrigeração a $1^{\circ} \mathrm{C} \pm 1^{\circ} \mathrm{C}$. 
Os teores de acidez titulável foram afetados pelo período de armazenamento com um ligeiro decréscimo para a cenoura e pimentão minimamente processados, quando considerados $01^{\circ}$ e $021^{\circ}$ dias de armazenamento. A salada mista, apesar de ter apresentado variação estatística para os tratamentos $(p \leq 0,05)$, mostrou que o embalamento sob ar atmosférico, vácuo e atmosfera modificada, apresentou valores próximos e comportamento semelhante durante o armazenamento.

Benedetti et al. (2002) encontraram um decréscimo na acidez, em ácido cítrico/100g, de 0,08 para 0,06 g em pimentões verdes cortados em rodelas, acondicionados em bandejas de poliestireno e armazenados por 10 dias sob temperaturas de 5 e $10^{\circ} \mathrm{C}$. Carlin et al. (1990), relataram um decréscimo na acidez, expressa em ácido málico em cenoura ralada e embalada sob atmosfera modificada $\left(10 \%\right.$ de $\mathrm{O}_{2}$ e $\left.40 \% \quad \mathrm{CO}_{2}\right)$, durante os 10 dias de armazenamento a $10^{\circ} \mathrm{C}$.

Kakiomenou et al. (1996), estudaram as alterações sensoriais em cenouras minimamente processadas e demostraram que houve aumento no teor de ácidos orgânicos, com conseqüente diminuição nos valores das notas de textura, caracterizado pelo amolecimento dos tecidos durante 0 armazenamento, fato não ocorrido nesta pesquisa, onde observourse notas satisfatórias para este atributo sensorial.

\subsection{3 pH}

Em cenoura minimamente processada, observou-se uma interação significativa $(p \leq 0,05)$ entre os tratamentos e o tempo de armazenamento para o $\mathrm{pH}$, encontrando-se valores entre 6,1 a 6,7 durante todo o período. O pimentão e a salada mista minimamente processados, tiveram $0 \mathrm{pH}$ afetado significativamente $(p \leq 0,05)$ durante 0 armazenamento, apresentando uma variação de 5,4 a 6,6 e 6,1 a 6,4, respectivamente, como pode-se observar na Tabela 8 e Figura 9. 
Tabela 8. pH em cenoura, pimentão e salada mista minimamente processados, embalados sob ar atmosférico, vácuo e atmosfera modificada, armazenadas sob refrigeração a $1^{\circ} \mathrm{C} \pm 1^{\circ} \mathrm{C}$.

\begin{tabular}{|c|c|c|c|c|c|c|}
\hline \multirow{3}{*}{ Produtos } & \multirow{3}{*}{ Tratamentos } & \multicolumn{4}{|c|}{$\mathrm{pH}$} & \multirow{3}{*}{ Médias } \\
\hline & & \multicolumn{4}{|c|}{ Dias } & \\
\hline & & 1 & 7 & 14 & 21 & \\
\hline \multirow{4}{*}{ Cenoura } & $\mathrm{Ar}$ & 6,45 & 6,41 & 6,55 & 6,71 & $6,53 \mathrm{a}$ \\
\hline & Vácuo & 6,50 & 6,13 & 6,25 & 6,67 & $6,39 a$ \\
\hline & Atm & 6,52 & 6,15 & 6,16 & 6,13 & $6,24 \quad b$ \\
\hline & Médias & $6,49 \mathrm{~A}$ & $6,23 \mathrm{~B}$ & $6,32 \mathrm{AB}$ & $6,50 \mathrm{~A}$ & \\
\hline \multirow{3}{*}{ Pimentão } & Ar & 5,62 & 5,41 & 5,82 & 6,24 & $5,77 \mathrm{a}$ \\
\hline & Vácuo & 5,64 & 5,76 & 6,37 & 6,60 & $6,09 \mathrm{a}$ \\
\hline & ${ }_{\text {Médias }}$ & $\begin{array}{c}5,44 \\
5,57 \mathrm{~B}\end{array}$ & $\begin{array}{c}5,45 \\
5,54 \mathrm{~B}\end{array}$ & $\begin{array}{c}6,14 \\
6,11 \mathrm{~A}\end{array}$ & $\begin{array}{r}6,39 \\
6,41 A\end{array}$ & $5,86 a$ \\
\hline \multirow{4}{*}{$\begin{array}{l}\text { Salada } \\
\text { mista }\end{array}$} & $\mathrm{Ar}$ & 6,08 & 6,25 & 6,48 & 6,39 & $6,30 \mathrm{a}$ \\
\hline & Vácuo & 6,08 & 6,23 & 6,33 & 6,26 & $6,23 a$ \\
\hline & Atm & 6,07 & 6,21 & 6,35 & 6,35 & $6,25 \mathrm{a}$ \\
\hline & Médias & $6,08 \mathrm{C}$ & $6,23 \mathrm{~B}$ & $6,39 \mathrm{~A}$ & $6,33 A B$ & \\
\hline
\end{tabular}

Nota: Valores seguidos com a mesma letra maiúscula, dentro da mesma linha, e com a mesma letra minúscula, dentro da mesma subcoluna, não diferem entre si estatisticamente $(p<0,05)$.

Os valores de $\mathrm{pH}$ tiveram um aumento nos três experimentos, cenoura, salada mista e pimentão minimamente processados, durante o armazenamento refrigerado, o que pode estar relacionado com os menores valores de ácidos orgânicos encontrados, ocorrendo o mesmo em pesquisa realizada por Fantuzzi (1999), onde o $\mathrm{pH}$ das amostras de repolho minimamente processado aumentou de um valor inicial de 5,6 para um valor médio de 6,5, após 20 dias de armazenamento sob as temperaturas de $1^{\circ} \mathrm{C}, 5^{\circ} \mathrm{C}$ e $12^{\circ} \mathrm{C}$. Bittencourtt et al. (2000) também encontraram, para couve minimamente processada, um aumento no $\mathrm{pH}$ de 6,3 para 6,8 e 7,2 durante o armazenamento a $5^{\circ} \mathrm{C}$ e $10^{\circ} \mathrm{C}$, respectivamente. 

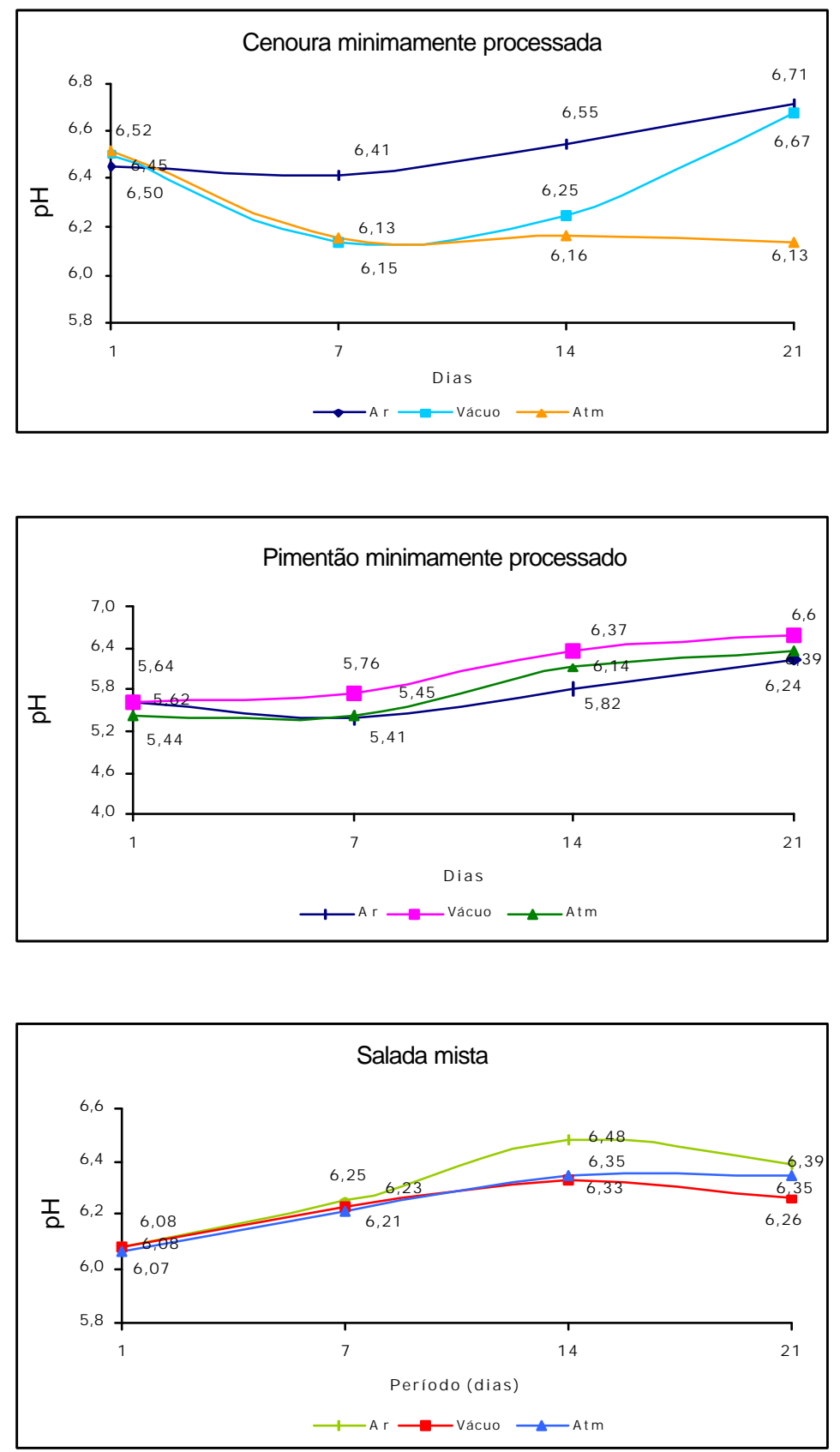

Figura 9 - $\mathrm{pH}$ em cenouras, pimentões e salada mista minimamente processados, embalados sob ar atmosférico, vácuo e atmosfera modificada, armazenados sob refrigeração a $1^{\circ} \mathrm{C} \pm 1^{\circ} \mathrm{C}$. 
Em experimentos com melões elaborados como fresh-cut e armazenados a $4^{\circ} \mathrm{C}$ por 14 dias, Lamikanra \& Watson (2003) avaliaram as alterações bioquímicas destes frutos em comparação aos melões inteiros armazenados a temperatura de abuso ( $\left.20^{\circ} \mathrm{C}\right)$. Não ocorreram diferenças para acidez titulável, pH, graus brix e teor de ácidos orgânicos, sob refrigeração durante as 2 semanas. Após 2 dias, a $20^{\circ} \mathrm{C}$, o ácido lático foi 0 ácido dominante, diferente da fruta fresca onde predominaram o oxálico, cítrico, málico e succínico.

Os resultados encontrados nesta pesquisa diferiram daqueles relatados por Abdul-Raouf et al. (1993), os quais encontraram na salada mista de cenoura, alface e pepino minimamente processados, um decréscimo nos valores de $\mathrm{pH}$ quando embaladas sob atmosfera modificada (3\% de $\mathrm{O}_{2}$ e $97 \%$ de $\mathrm{N}_{2}$ ) e armazenadas sob temperaturas de $5^{\circ} \mathrm{C}, 12^{\circ} \mathrm{C}$ e $21^{\circ} \mathrm{C}$.

García-Gimeno \& Zurera-Cosano (1997) observaram maior valor para $\mathrm{pH}$, de aproximadamente 6,5, em salada mista composta por cenoura, alface e repolho roxo, armazenadas sob temperatura de $4^{\circ} \mathrm{C}$. As amostras armazenadas a $15^{\circ} \mathrm{C}$ apresentaram $\mathrm{pH} 4,0$.

Segundo Piga et al. (2003), em peras (variedade Gialla) embaladas em filme plástico de alta permeabilidade a gases e mantidas a $4^{\circ} \mathrm{C}$ por 9 dias, alterações significativas ocorreram no pH e na acidez sem, no entanto, provocar efeito adverso nas propriedades sensoriais.

\subsubsection{Vitamina C}

A vitamina $C$ é a mais instável das vitaminas por ser sensível aos agentes físico-químicos como luz, oxigênio e calor. A perda de sua estabilidade é citada por Klein (1987) como conseqüência de vários fatores, como rompimento celular por dano ao tecido, corte ou moedura.

Os teores de vitamina $C$ para as amostras de cenoura e pimentão minimamente processados não apresentaram diferença estatística para os 
tratamentos nem para os períodos (Tabela 9 e Figura 10). Houve retenção da vitamina $\mathrm{C}$ até os 21 dias de armazenamento para as cenouras em todos os tipos de tratamentos realizados.

Para os pimentões, os valores oscilaram com ligeira queda aos 14 dias para a embalagem a vácuo. Resultados semelhantes foram encontrados por Benedetti et al. (2002) em pimentões cortados em rodelas e em tiras, acondicionados em bandejas de poliestireno expandido, envoltas por filme de policloreto de vinila (PVC) esticável, armazenados a $5^{\circ} \mathrm{C}$, durante 10 dias. $\mathrm{O}$ efeito protetor na retenção da vitamina $C$ esperado para embalagem a vácuo, provavelmente não ocorreu devido a possibilidade de perda desta vitamina pelo exsudato ocorrido no pimentão.

Para a salada mista, os teores permaneceram com 12,5 mg/g (Tabela 9), inalterados ao longo do tempo de armazenamento, demonstrando que a vitamina C não foi afetada. Senesi et al. (2000), também demonstraram que o teor de vitamina $\mathrm{C}$ de vegetais minimamente processados manteve-se constante durante 11 dias de armazenamento sob temperatura de $8^{\circ} \mathrm{C}$.

Tabela 9. Vitamina C em cenoura, pimentão e salada mista minimamente processados, embalados sob ar atmosférico, vácuo e atmosfera modificada, armazenadas sob refrigeração a $1^{\circ} \mathrm{C} \pm 1^{\circ} \mathrm{C}$.

\begin{tabular}{|c|c|c|c|c|c|c|}
\hline \multirow{3}{*}{ Produtos } & \multirow{3}{*}{ Tratamentos } & \multicolumn{4}{|c|}{ Vitamina C (mg/100g) } & \multirow{3}{*}{ Médias } \\
\hline & & \multicolumn{4}{|c|}{ Dias } & \\
\hline & & 1 & 7 & 14 & 21 & \\
\hline \multirow{4}{*}{ Cenoura } & $\mathrm{Ar}$ & 13,89 & 13,89 & 13,89 & 12,50 & $13,54 \mathrm{a}$ \\
\hline & Vácuo & 13,89 & 15,28 & 15,28 & 13,89 & $14,59 \mathrm{a}$ \\
\hline & Atm & 13,89 & 15,28 & 13,89 & 13,89 & $14,24 a$ \\
\hline & Médias & $13,89 \mathrm{~A}$ & $14,82 \mathrm{~A}$ & $14,35 \mathrm{~A}$ & $13,43 \mathrm{~A}$ & \\
\hline \multirow{4}{*}{ Pimentão } & Ar & 146,3 & 120,0 & 135,0 & 130,0 & $132,8 \mathrm{a}$ \\
\hline & Vácuo & 141,4 & 130,0 & 115,0 & 115,0 & $125,3 \mathrm{a}$ \\
\hline & Atm & 146,3 & 120,0 & 132,5 & 122,5 & $130,3 \mathrm{a}$ \\
\hline & Médias & 144,7 A & $123,3 \mathrm{~A}$ & $127,5 \mathrm{~A}$ & $122,5 \mathrm{~A}$ & \\
\hline
\end{tabular}

Nota: Valores seguidos com a mesma letra maiúscula, dentro da mesma linha, e com a mesma letra minúscula, dentro da mesma subcoluna, não diferem entre si estatisticamente $(p<0,05)$. 
Teles et al. (2000), relataram que couve minimamente processada embalada em filmes plásticos de poliolefina e atmosfera modificada (10\% de $\mathrm{O}_{2}, 5 \%$ de $\mathrm{CO}_{2}$ e $85 \%$ de $\mathrm{N}_{2}$ ), continha, ao final do $13^{\circ}$ dia de armazenamento sob temperatura de $5^{\circ} \mathrm{C}, 80 \%$ da vitamina $\mathrm{C}$ em relação ao teor inicial do experimento.

A retenção de vitamina $\mathrm{C}$ e a capacidade antioxidante foram registradas por Piga et al. (2003) em peras (variedade Gialla) embaladas com filmes de alta permeabilidade aos gases, mantidas a $4^{\circ} \mathrm{C}$ por 9 dias.
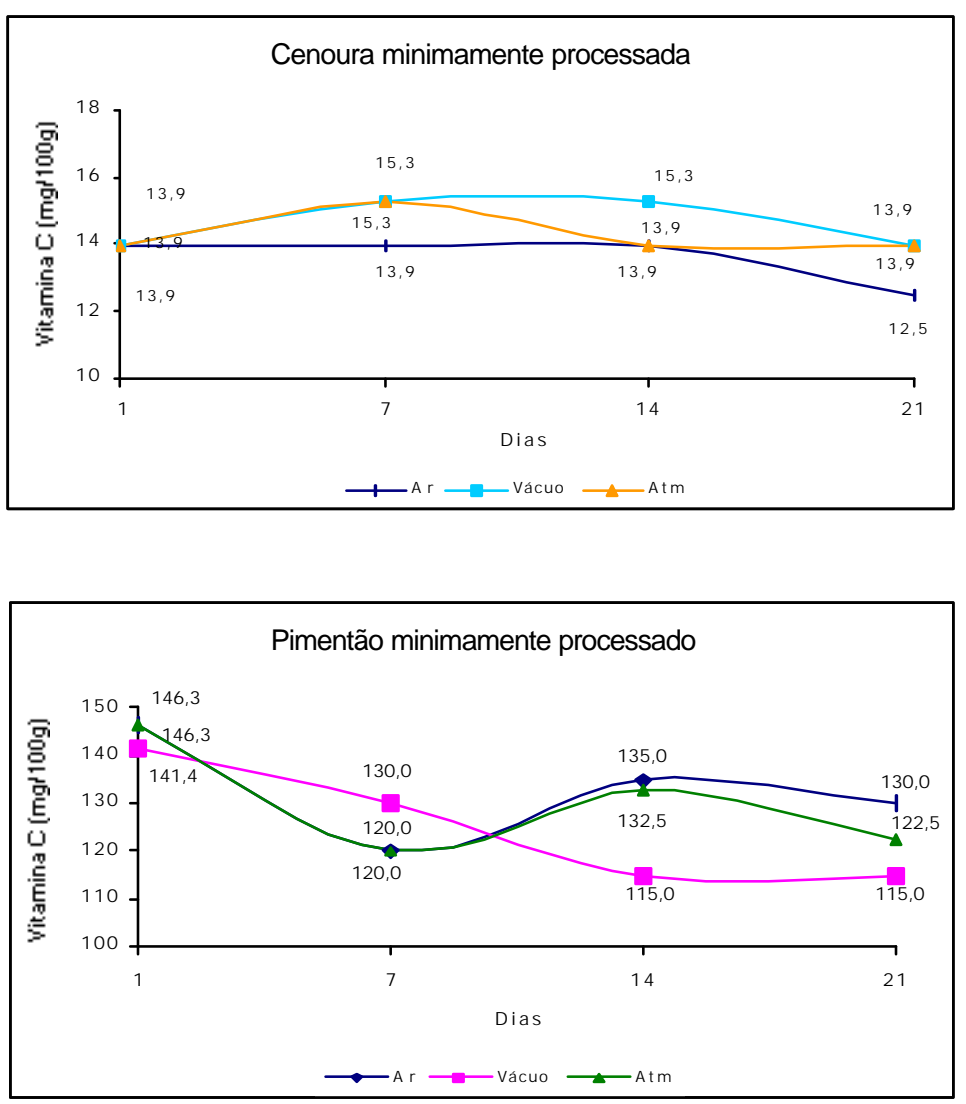

Figura 10 - Vitamina C em cenouras e pimentões minimamente processados, embalados sob ar atmosférico, vácuo e atmosfera modificada, armazenados sob refrigeração a $1^{\circ} \mathrm{C} \pm 1^{\circ} \mathrm{C}$. 


\subsection{5 $\beta$-caroteno}

Para os valores de $\beta$-caroteno em cenoura, pimentão e salada mista minimamente processados, observou-se variação estatística $(p \leq 0,05)$ para os tratamentos e tempo de armazenamento.

A cenoura embalada sob ar atmosférico manteve o teor de $\beta$-caroteno praticamente constante durante as três primeiras semanas de armazenamento, pouco diferindo de quando embalada a vácuo. Já as amostras embaladas sob atmosfera modificada apresentaram os menores valores durante todo o período de armazenamento (Tabela 10 e Figura 11). Li \& Barth (1998) demonstraram que os teores de $\beta$-caroteno decresceram continuamente durante 0 armazenamento a $1^{\circ} \mathrm{C}$, em cenoura descascada, embalada em filme plástico, onde após 28 dias apresentaram cerca de 33\% do teor inicial. Nesta pesquisa, no período compreendido entre o $14^{\circ}$ e $21^{\circ}$ dias, ocorreu diminuição no teor de $\beta$-caroteno no tratamento sob ar atmosférico, concordando com Li \& Barth (1998)

Foi observado que os pimentões embalados sob vácuo e atmosfera modificada tiveram uma diminuição nos teores de $\beta$-caroteno, após a primeira semana de armazenamento, mantendo-se praticamente constantes até o final do experimento. Fato semelhante ocorreu em pesquisa realizada por Hussein et al. (2000), que relataram uma diminuição nos teores de $\beta$-caroteno em pimentões embalados a vácuo no $10^{\circ}$ dia de armazenamento. Os valores para as amostras embaladas sob vácuo mostraram-se superiores aos demais durante todo o período de armazenamento para cenoura e pimentão (Tabela 10 e Figura 11).

Tanto a embalagem a vácuo quanto a atmosfera modificada, exerceram um efeito de proteção à retenção do $\beta$-caroteno nos pimentões e na salada mista em relação à embalagem sob ar atmosférico, o que pôde ser observado no $1^{\circ}$ dia do experimento (Tabela 10 e Figura 11). 
Para a salada mista, as amostras embaladas sob atmosfera modificada apresentaram maiores teores de $\beta$-caroteno que as amostras embaladas a vácuo e ar atmosférico, inclusive durante todo o período de armazenamento (Tabela 10 e Figura 11).

Tabela 10. $\beta$-caroteno em cenoura, pimentão e salada mista minimamente processados, embalados sob ar atmosférico, vácuo e atmosfera modificada, armazenadas sob refrigeração a $1^{\circ} \mathrm{C} \pm 1^{\circ} \mathrm{C}$.

\begin{tabular}{|c|c|c|c|c|c|c|}
\hline \multirow{3}{*}{ Produtos } & \multirow{3}{*}{ Tratamentos } & \multicolumn{4}{|c|}{$\beta$-caroteno } & \multirow{3}{*}{ Médias } \\
\hline & & \multicolumn{4}{|c|}{ Dias } & \\
\hline & & 1 & 7 & 14 & 21 & \\
\hline \multirow{4}{*}{ Cenoura } & $\mathrm{Ar}$ & 4,115 & 3,885 & 3,710 & 2,325 & $3,509 \quad b$ \\
\hline & Vácuo & 4,405 & 4,060 & 3,865 & 3,670 & $4,000 \mathrm{a}$ \\
\hline & Atm & 3,040 & 2,960 & 2,790 & 2,615 & 2,851 \\
\hline & Médias & $3,853 \mathrm{~A}$ & $3,635 \mathrm{~B}$ & $3,455 \mathrm{C}$ & $2,870 \mathrm{D}$ & \\
\hline \multirow{4}{*}{ Pimentão } & $\mathrm{Ar}$ & 0,195 & 0,190 & 0,165 & 0,160 & $0,178 \quad b$ \\
\hline & Vácuo & 0,340 & 0,205 & 0,190 & 0,170 & $0,226 \mathrm{a}$ \\
\hline & Atm & 0,250 & 0,180 & 0,145 & 0,145 & \multirow[t]{2}{*}{$0,180 \quad b$} \\
\hline & Médias & $0,262 \mathrm{~A}$ & $0,192 \mathrm{~B}$ & $0,167 \mathrm{~B}$ & $0,158 \mathrm{~B}$ & \\
\hline \multirow{4}{*}{ Salada } & $\mathrm{Ar}$ & 0,040 & 0,051 & 0,063 & 0,061 & 0,053 \\
\hline & Vácuo & 0,073 & 0,062 & 0,075 & 0,088 & $0,075 \mathrm{~b}$ \\
\hline & Atm & 0,076 & 0,082 & 0,098 & 0,115 & \multirow[t]{2}{*}{$0,093 \mathrm{a}$} \\
\hline & Médias & $0,062 \mathrm{D}$ & $0,065 \mathrm{C}$ & $0,079 \mathrm{~B}$ & $0,088 \mathrm{~A}$ & \\
\hline
\end{tabular}

Nota: Valores seguidos com a mesma letra maiúscula, dentro da mesma linha, e com a mesma letra minúscula, dentro da mesma subcoluna, não diferem entre si estatisticamente $(p<0,05)$. 

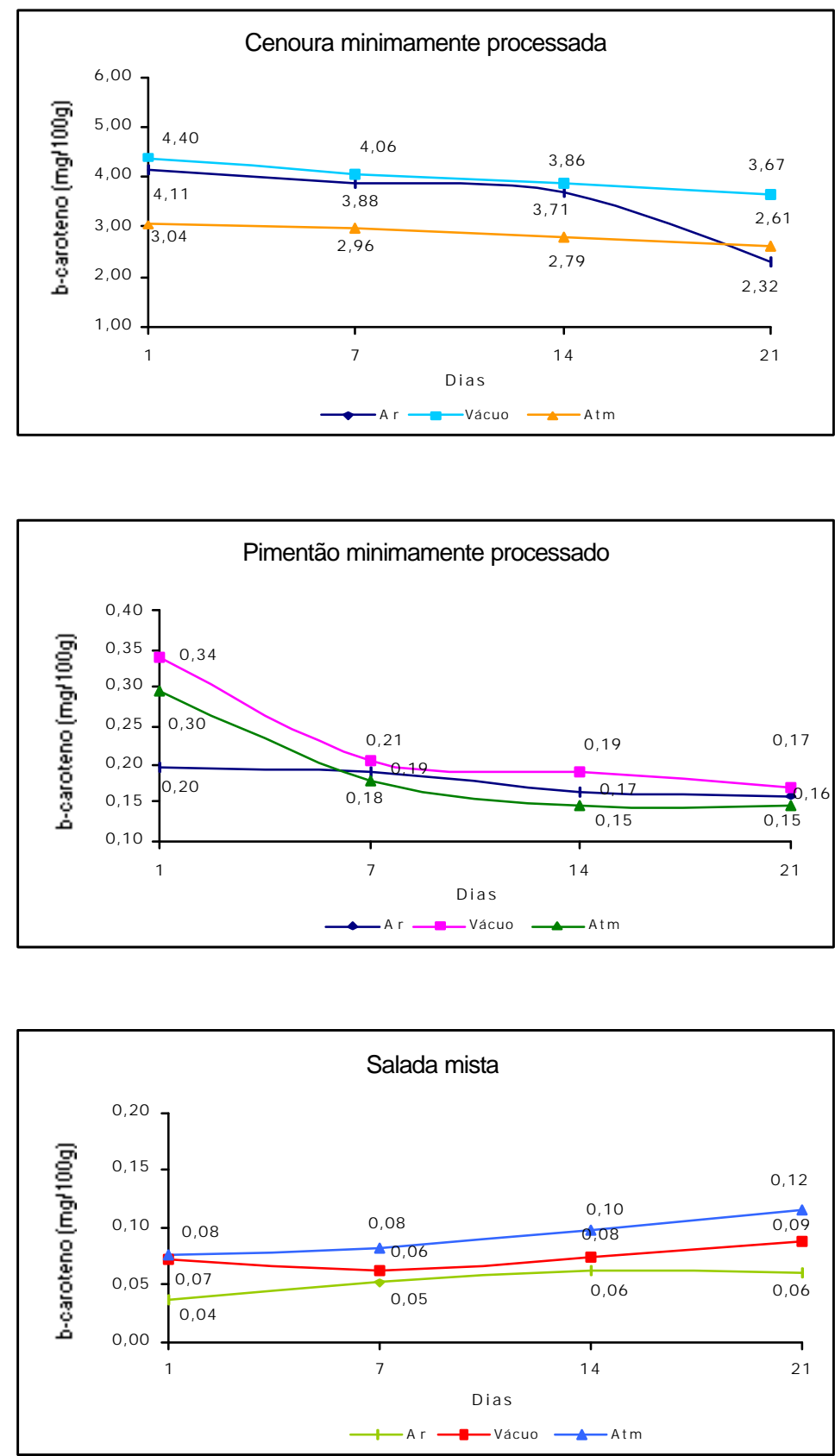

Figura 11 - $\beta$-caroteno em cenouras, pimentões e salada mista minimamente processados, embalados sob ar atmosférico, vácuo e atmosfera modificada, armazenados sob refrigeração a $1^{\circ} \mathrm{C} \pm 1^{\circ} \mathrm{C}$. 


\subsubsection{Minerais}

Em cenoura minimamente processada em todos os tratamentos, foram constatadas variações significativas $(p \leq 0,05)$ para o cobre, ferro, manganês, zinco, fósforo e magnésio durante o período de armazenamento. $O$ potássio e o cálcio tiveram uma oscilação ao longo do tempo, porém não significativas.

O cobre apresentou uma diminuição em seu teor nas duas últimas semanas, atingindo praticamente a metade do valor inicial. $O$ ferro apresentou diferença estatística para os tratamentos, porém manteve-se constante durante o período de armazenamento; os menores valores foram para as amostras embaladas sob vácuo. Já o manganês, zinco, fósforo e o magnésio, mantiveram-se praticamente estáveis durante esse período (Tabela 11).

Os teores encontrados nesta pesquisa, para todos os macros e micronutrientes em amostras de cenoura, nos quatro períodos de armazenamento, mostraram-se superiores aos encontrados para cenoura in natura nas tabelas de composição química dos alimentos, ENDEF (1977) e Franco (1999). Porém, foram inferiores aos encontrados por Furlani et al. (1978). Geralmente, a variação entre os teores de minerais das hortaliças de mesma variedade, se dá em função de diversos fatores como tempo de colheita, época do ano, adubação e tipo de solo (Malavolta et al., 1989). Estes fatores impedem que se faça comparações pontuais, a não ser que todas as variáveis sejam consideradas na pesquisa. 
Tabela 11. Minerais em cenoura minimamente processada, embalada sob ar atmosférico, vácuo e atmosfera modificada, armazenada sob refrigeração a $1^{\circ} \mathrm{C} \pm 1^{\circ} \mathrm{C}$.

\begin{tabular}{|c|c|c|c|c|c|c|c|}
\hline \multirow{2}{*}{\multicolumn{2}{|c|}{ Minerais }} & \multirow{3}{*}{ Tratamentos } & \multicolumn{4}{|c|}{ Cenoura } & \multirow{3}{*}{ Médias } \\
\hline & & & \multicolumn{4}{|c|}{ Dias } & \\
\hline & & & 1 & 7 & 14 & 21 & \\
\hline \multirow{15}{*}{$\mathrm{g} / \mathrm{kg}$} & \multirow{5}{*}{$\mathrm{P}$} & $\mathrm{Ar}$ & 2,72 & 2,76 & 2,00 & 2,03 & $2,38 a$ \\
\hline & & Vácuo & 2,73 & 2,86 & 2,59 & 2,33 & $2,63 a$ \\
\hline & & Atm & 2,74 & 2,69 & 1,90 & 2,04 & $2,34 \mathrm{a}$ \\
\hline & & Médias & $2,73 \mathrm{~A}$ & $2,77 \mathrm{~A}$ & $2,16 \mathrm{~B}$ & $2,13 \mathrm{~B}$ & \\
\hline & & $\mathrm{Ar}$ & 17,98 & 16,45 & 22,57 & 22,95 & $19,99 \mathrm{a}$ \\
\hline & \multirow{2}{*}{ K } & Vácuo & 19,51 & 18,36 & 25,63 & 22,19 & 21,42 a \\
\hline & & Atm & 23,72 & 21,42 & 21,04 & 23,20 & $22,34 \mathrm{a}$ \\
\hline & \multirow{6}{*}{$\mathrm{Ca}$} & Médias & $20,40 \mathrm{~A}$ & $18,74 \mathrm{~A}$ & $23,08 \mathrm{~A}$ & $24,74 \mathrm{~A}$ & \\
\hline & & $\mathrm{Ar}$ & 2,02 & 2,45 & 2,02 & 1,92 & $2,10 \mathrm{a}$ \\
\hline & & Vácuo & 2,12 & 2,07 & 1,70 & 1,65 & $1,89 a$ \\
\hline & & Atm & 2,10 & 2,42 & 1,85 & 1,87 & $2,06 \mathrm{a}$ \\
\hline & & Médias & $2,08 \mathrm{~A}$ & $2,31 \mathrm{~A}$ & $1,86 \mathrm{~A}$ & $2,06 \mathrm{~A}$ & \\
\hline & & $\mathrm{Ar}$ & 0,97 & 1,01 & 0,61 & 0,75 & $0,84 \mathrm{a}$ \\
\hline & \multirow{2}{*}{$\mathrm{Mg}$} & Vácuo & 1,08 & 0,89 & 0,75 & 0,66 & $0,85 a$ \\
\hline & & Atm & 0,93 & 1,01 & 0,61 & 0,89 & $0,86 \mathrm{a}$ \\
\hline \multirow{12}{*}{$\mathrm{mg} / \mathrm{kg}$} & \multirow{5}{*}{$\mathrm{Cu}$} & Médias & $0,99 \mathrm{~A}$ & $0,97 \mathrm{~A}$ & $0,66 \mathrm{~B}$ & $0,77 \mathrm{~B}$ & \\
\hline & & $\mathrm{Ar}$ & 8,90 & 8,50 & 5,75 & 4,80 & 6,99 a \\
\hline & & Vácuo & 9,55 & 9,05 & 4,80 & 4,95 & $7,09 \mathrm{a}$ \\
\hline & & Atm & 8,50 & 7,95 & 4,25 & 5,85 & $6,64 a$ \\
\hline & & Médias & $8,98 \mathrm{~A}$ & $8,50 \mathrm{~A}$ & $4,93 \mathrm{~B}$ & $5,20 \mathrm{~B}$ & \\
\hline & \multirow{4}{*}{$\mathrm{Mn}$} & $\mathrm{Ar}$ & 15,1 & 16,1 & 15,1 & 16,6 & 15,72 a \\
\hline & & Vácuo & 14,7 & 15,6 & 15,8 & 17,3 & $15,85 a$ \\
\hline & & Atm & 15,3 & 15,9 & 16,5 & 17,7 & $16,35 \mathrm{a}$ \\
\hline & & Médias & $14,67 \mathrm{~B}$ & $16,42 \mathrm{AB}$ & $17,72 \mathrm{~A}$ & $18,92 \mathrm{~A}$ & \\
\hline & \multirow{3}{*}{$\mathrm{Zn}$} & Ar & 26,55 & 27,10 & 24,25 & 25,15 & 25,76 a \\
\hline & & Vácuo & 26,00 & 26,40 & 25,60 & 25,55 & $25,89 a$ \\
\hline & & ${ }_{\text {Médias }}$ & $\begin{array}{c}25,60 \\
26,05 \mathrm{AB}\end{array}$ & $\begin{array}{c}26,50 \\
27,07 \mathrm{~A}\end{array}$ & $\begin{array}{c}24,40 \\
24,52 \text { B }\end{array}$ & $\begin{array}{c}25,30 \\
25,33 \mathrm{AB}\end{array}$ & $25,45 a$ \\
\hline
\end{tabular}

Nota: Valores seguidos com a mesma letra maiúscula, dentro da mesma linha, e com a mesma letra minúscula, dentro da mesma subcoluna, não diferem entre si estatisticamente $(p<0,05)$.

Para o pimentão minimamente processado, houve variação estatística $(\mathrm{p} \leq 0,05)$ para o cálcio, magnésio e manganês durante o período de armazenamento. O cobre, ferro, potássio, zinco e fósforo, tiveram apenas uma oscilação ao longo do tempo, sem diferirem significativamente (Tabela 12).

Para o cálcio e magnésio, houve uma oscilação nos valores em todos os tratamentos. O manganês sofreu uma ligeira diminuição em seu teor na última 
semana de armazenamento para o ar atmosférico, vácuo e atmosfera modificada.

Tabela 12. Minerais em pimentão minimamente processado, embalado sob ar atmosférico, vácuo e atmosfera modificada, armazenado sob refrigeração a $1^{\circ} \mathrm{C} \pm 1^{\circ} \mathrm{C}$.

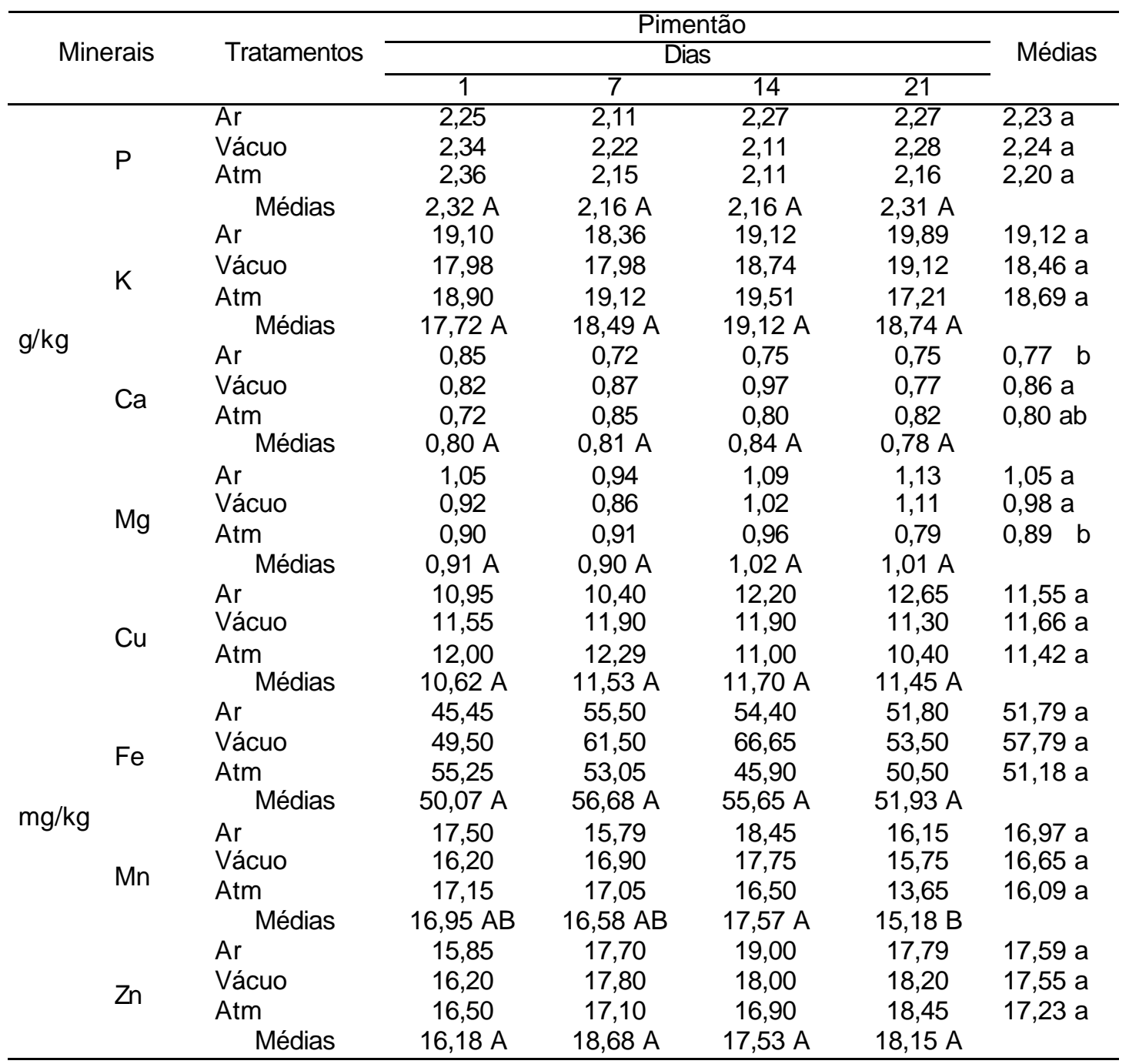

Nota: Valores seguidos com a mesma letra maiúscula, dentro da mesma linha, e com a mesma letra minúscula, dentro da mesma subcoluna, não diferem entre si estatisticamente $(p<0,05)$. 
Para a salada mista, não foram constatadas diferenças estatísticas entre os diversos tratamentos; os teores em minerais permaneceram praticamente constantes durante o período de armazenamento (Tabela 13).

Tabela 13. Minerais em salada mista minimamente processada, embalada sob ar atmosférico, vácuo e atmosfera modificada, armazenada sob refrigera ção a $1^{\circ} \mathrm{C} \pm 1^{\circ} \mathrm{C}$.

\begin{tabular}{|c|c|c|c|c|c|c|}
\hline \multirow{3}{*}{ Minerais } & \multirow{3}{*}{ Tratamentos } & \multicolumn{4}{|c|}{ Salada mista } & \multirow{3}{*}{ Média } \\
\hline & & \multicolumn{4}{|c|}{ Dias } & \\
\hline & & 1 & 7 & 14 & 21 & \\
\hline & $\overline{\mathrm{Ar}}$ & 2,60 & 2,72 & 2,82 & 2,75 & 2,72 a \\
\hline \multirow{13}{*}{$\mathrm{g} / \mathrm{kg}$} & Vácuo & 2,56 & 2,63 & 2,63 & 2,54 & 2,59 a \\
\hline & Atm & 2,51 & 2,70 & 2,51 & 2,57 & 2,57 a \\
\hline & Médias & $2,51 \mathrm{~A}$ & $2,68 \mathrm{~A}$ & $2,65 \mathrm{~A}$ & $2,62 \mathrm{~A}$ & \\
\hline & $\mathrm{Ar}$ & 15,30 & 14,54 & 17,98 & 16,45 & $16,07 \mathrm{a}$ \\
\hline & Vácuo & 13,39 & 14,90 & 16,07 & 14,15 & $14,63 \mathrm{a}$ \\
\hline & Atm & 14,92 & 14,15 & 14,54 & 17,98 & $15,40 \mathrm{a}$ \\
\hline & Médias & $14,54 \mathrm{~A}$ & $15,81 \mathrm{~A}$ & $16,20 \mathrm{~A}$ & $16,19 \mathrm{~A}$ & \\
\hline & $\mathrm{Ar}$ & 2,47 & 1,90 & 2,05 & 1,85 & 2,07 a \\
\hline & Vácuo & 2,17 & 2,17 & 2,30 & 2,07 & 2,18 a \\
\hline & Atm & 2,07 & 2,15 & 1,77 & 2,12 & 2,03 a \\
\hline & Médias & $2,24 \mathrm{~A}$ & $2,07 \mathrm{~A}$ & $2,04 \mathrm{~A}$ & $2,01 \mathrm{~A}$ & \\
\hline & $\mathrm{Ar}$ & 1,52 & 1,48 & 1,49 & 1,45 & $1,48 \quad a$ \\
\hline & Vácuo & 1,38 & 1,58 & 1,37 & 1,23 & 1,39 a \\
\hline $\mathrm{Mg}$ & Atm & 1,42 & 1,33 & 1,22 & 1,40 & $1,34 \mathrm{a}$ \\
\hline & Médias & $1,44 \mathrm{~A}$ & $1,36 \mathrm{~A}$ & $1,36 \mathrm{~A}$ & $1,42 \mathrm{~A}$ & \\
\hline \multirow{4}{*}{$\mathrm{Cu}$} & $\mathrm{Ar}$ & 7,55 & 6,70 & 7,20 & 6,20 & 6,91 a \\
\hline & Vácuo & 6,80 & 7,35 & 7,05 & 6,25 & 6,86 a \\
\hline & Atm & 6,65 & 6,65 & 5,90 & 7,20 & 6,60 a \\
\hline & Médias & $7,00 \mathrm{~A}$ & $6,90 \mathrm{~A}$ & $6,72 \mathrm{~A}$ & $6,55 \mathrm{~A}$ & \\
\hline \multirow{5}{*}{$\mathrm{mg} / \mathrm{kg}$} & $\mathrm{Ar}$ & 56,65 & 50,59 & 57,15 & 48,45 & $53,21 a$ \\
\hline & Vácuo & 52,79 & 50,79 & 53,65 & 38,05 & $48,82 \mathrm{a}$ \\
\hline & Atm & 48,90 & 50,79 & 49,79 & 50,90 & $50,10 a$ \\
\hline & Médias & $52,78 \mathrm{~A}$ & $50,72 \mathrm{~A}$ & $53,53 \mathrm{~A}$ & $45,80 \mathrm{~A}$ & \\
\hline & $\mathrm{Ar}$ & 45,05 & 40,30 & 44,25 & 43,70 & $43,33 a$ \\
\hline \multirow{2}{*}{$\mathrm{Mn}$} & Vácuo & 45,30 & 44,40 & 47,15 & 42,30 & $44,79 \mathrm{a}$ \\
\hline & Atm & 43,10 & 45,20 & 39,70 & 41,90 & $42,47 \mathrm{a}$ \\
\hline \multirow{5}{*}{$\mathrm{Zn}$} & Médias & $44,48 \mathrm{~A}$ & $43,30 \mathrm{~A}$ & $43,70 \mathrm{~A}$ & $45,42 \mathrm{~A}$ & \\
\hline & $\mathrm{Ar}$ & 29,20 & 27,40 & 26,80 & 22,50 & $26,47 \mathrm{a}$ \\
\hline & Vácuo & 27,15 & 27,00 & 30,00 & 26,25 & $27,60 \mathrm{a}$ \\
\hline & Atm & 25,85 & 28,00 & 28,90 & 28,90 & $27,91 \mathrm{a}$ \\
\hline & Médias & $27,40 \mathrm{~A}$ & $27,47 \mathrm{~A}$ & $30,87 \mathrm{~A}$ & $25,88 A$ & \\
\hline
\end{tabular}

Nota: Valores seguidos com a mesma letra maiúscula, dentro da mesma linha, e com a mesma letra minúscula, dentro da mesma subcoluna, não diferem entre si estatisticamente $(p<0,05)$. 
As variações nos teores e tpos de minerais foram distintos para cada produto e tratamentos analisados, mostrando que as atmosferas utilizadas no embalamento, possivelmente, não influenciaram nas variações ocorridas.

\subsection{Análises microbiológicas}

As contagens totais de bactérias em hortaliças são utilizadas como parâmetros da carga microbiana presente, não indicando se a população tem efeito benéfico ou prejudicial. Contudo, servem como um alerta das condições de higiene durante a manipulação e armazenamento, como também dos potenciais riscos oferecidos à saúde do consumidor (Brasil, 1997; ICMSF, 1985).

Para frutas e hortaliças minimamente processadas não há informações na legislação brasileira quanto aos limites de contagens tolerados para microrganismos. Para "hortaliças frescas, refrigeradas ou congeladas", a Portaria no 451 de 19 de setembro de 1997 estipula para Salmonella, a ausência em $25 \mathrm{~g}$ e o limite para Coliformes fecais de $2 \times 10^{2} \mathrm{NMP} / \mathrm{g}$ (Brasil, 1997). Porém, para compatibilizar a legislação nacional com os regulamentos harmonizados no Mercosul, esta Portaria foi revogada pela Resolução RDC no 12 de 02 de janeiro de 2001, onde os padrões microbiológicos para hortaliças frescas, in natura, preparadas (descascadas ou selecionadas ou fracionadas), sanificadas, refrigeradas ou congeladas, para o consumo direto, passaram a ser para Salmonella sp, ausência em $25 \mathrm{~g}$ e de $10^{2} \mathrm{NMP} / \mathrm{g}$ para coliformes a $45^{\circ} \mathrm{C}$ (ANVISA, 2001).

O resultado das análises microbiológicas da cenoura e salada mista minimamente processadas foi negativo para presença de coliformes totais e fecais, anaeróbios mesófilos e Salmonella. Apenas os psicrotróficos (Figura 12) apresentaram ligeiro crescimento durante o período de armazenamento das amostras embaladas sob ar atmosférico, vácuo e atmosfera modificada. 
Para o pimentão minimamente processado foi detectada a presença de coliformes totais e anaeróbios mesófilos (Tabela 14) e psicrotróficos (Figura 12) durante o período de armazenamento para todos os tratamentos.

Tabela 14. Coliformes totais e anaeróbios mesófilos em pimentões minimamente processados, armazenados a $1^{\circ} \mathrm{C} \pm 1^{\circ} \mathrm{C}$.

\begin{tabular}{lcccc}
\hline \multirow{2}{*}{ Tratamentos } & \multicolumn{4}{c}{ Coliformes Totais (NMP/g) } \\
\cline { 2 - 5 } & \multicolumn{4}{c}{ Dias de armazenamento } \\
\cline { 2 - 5 } & $<10 / \mathrm{g}$ & 7 & 14 & 21 \\
\hline Ar atmosférico & $<10 / \mathrm{g}$ & $4,6 \times 10^{2}$ & $<10 / \mathrm{g}$ & $4,0 \times 10$ \\
Vácuo & $<10 / \mathrm{g}$ & $4,0 \times 10$ & $<10 / \mathrm{g}$ & $4,0 \times 10^{2}$ \\
Atmosfera modificada & & Anaeróbios mesófilos (UFC/g) & \\
Ar atmosférico & $2,3 \times 10^{3}$ & $4,2 \times 10^{3}$ & $3,0 \times 10^{4}$ & $7,4 \times 10^{5}$ \\
Vácuo & $1,6 \times 10^{3}$ & $4,2 \times 10^{3}$ & $3,4 \times 10^{4}$ & $6,6 \times 10^{5}$ \\
Atmosfera modificada & $2,4 \times 10^{3}$ & $4,1 \times 10^{3}$ & $4,2 \times 10^{4}$ & $1,4 \times 10^{5}$ \\
\hline
\end{tabular}

A maior deterioração observada no pimentão em relação æ̀ outras hortaliças analisadas pode ter ocorrido, provavelmente, pela mais alta contaminação inicial, pela maior disponibilidade de nutrientes na superfície do corte (Bennik et al., 1998) e por conter mais açúcar do que os outros vegetais, o que estimula o crescimento microbiano (Babic et al., 1992; Fleet, 1992).

Senesis et al. (2000), demonstraram que houve rápida proliferação de microrganismos, incluindo bactérias ácido láticas, em pimentões verdes armazenados sob atmosfera modificada com altas concentrações de $\mathrm{CO}_{2}$. Após sete dias de armazenamento sob temperatura de $8^{\circ} \mathrm{C}$, as contagens totais de microrganismos foram de $10^{7}-10^{8} \mathrm{UFC} / \mathrm{g}$. Nesta pesquisa, até $07^{0} \mathrm{dia}$, a contagem de anaeróbios mesófilos se manteve em $10^{3} \mathrm{UFC} / \mathrm{g}$, porém tendo um aumento de dois ciclos logarítmicos ao final dos 21 dias de armazenamento, quando os pimentões se mostraram visivelmente alterados. 

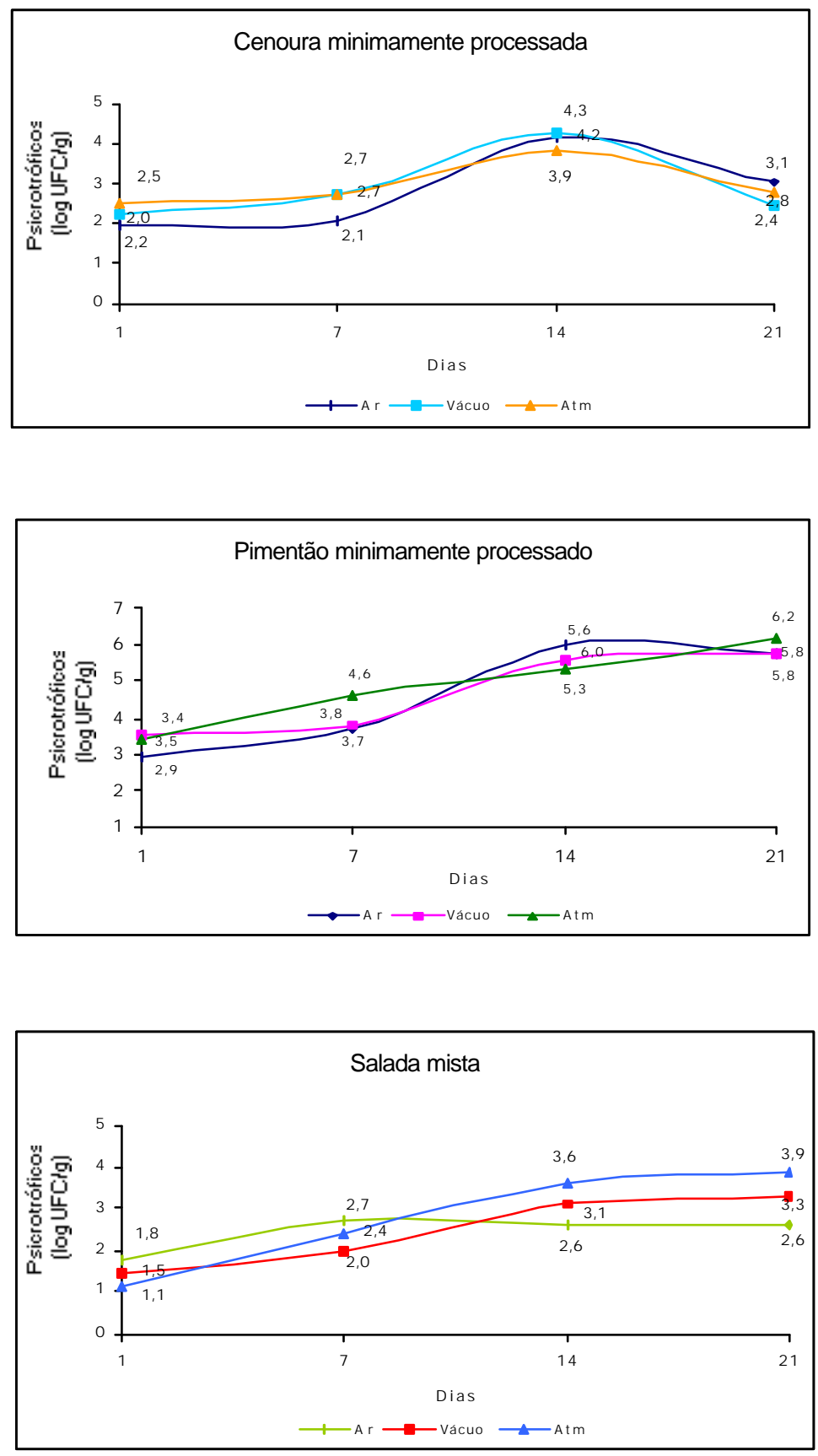

Figura 12 - Psicrotróficos em cenouras, pimentões e salada mista minimamente processados, embalados sob ar atmosférico, vácuo e atmosfera modificada, armazenados sob refrigeração a $1^{\circ} \mathrm{C} \pm 1^{\circ} \mathrm{C}$. 
Nesta pesquisa, a contagem de psicrotróficos em cenoura, salada mista e pimentão minimamente processados, em todos os tratamentos, foi de $10^{2} \mathrm{a}$ $10^{5} \mathrm{UFC} / \mathrm{g}, 10^{1}$ a $10^{3} \mathrm{UFC} / \mathrm{g}$ e $10^{3}$ a $10^{6} \mathrm{UFC} / \mathrm{g}$, respectivamente. Essa contagem obtida foi menor quando comparada à encontrada por GarcíaGimeno \& Zurera-Cosano (1997), que observaram um aumento de $10^{5}$ para $10^{7}$ UFC/g na contagem de microrganismos psicrotróficos em salada mista composta por alface, cenoura e repolho roxo, embalada em filme de polipropileno sem injeção de gás, durante 9 dias de armazenamento sob refrigeração a $4^{\circ} \mathrm{C}$.

Rosa et al. (2002) demonstraram que as contagens de bactérias psicrotróficas em cenoura, beterraba e salada mista minimamente processadas de diferentes marcas comerciais, mostraram-se bastante elevadas, com índices iniciais de $10^{6}$ a $10^{9} \mathrm{UFC} / \mathrm{g}$. Os autores citam que, embora $25 \%$ das amostras tenham apresentado uma redução de 1 a 2 ciclos logarítmicos no decorrer do armazenamento, elas apresentaram a contagem final $>10^{7} \mathrm{UFC} / \mathrm{g}$. Este índice é considerado perigoso, não só por acelerar o processo de deterioração, como também por indicar predisponibilidade para a presença de bactérias friotolerantes como Listeria monocytogenes.

$\mathrm{O}$ risco quantitativo, segundo a $\mathrm{FAO} / \mathrm{WHO}$, para a Listeria monocytogenes em alimentos ready-to-eat está na faixa de ausência em $25 \mathrm{~g}$ para 1000 colônias/g ou mL no produto no ponto de venda (Rocourt et al., 2003).

\subsection{Análise sensorial}

Foi realizada uma avaliação da preferência do provador em relação a aparência do produto embalado. Nos três experimentos, 54\%, 71\% e 50\% dos provadores preferiram embalagem sob atmosfera modificada para cenoura, pimentão e salada mista, respectivamente, conforme informações registradas nas fichas, como aspecto mais agradável, por apresentar maior frescor e ter 
maior semelhança com o produto in natura. $\mathrm{O}$ restante dos provadores optou pela embalagem a vácuo, alegando facilidade no manuseio do produto e no armazenamento doméstico.

\subsubsection{Textura}

Para a cenoura minimamente processada, não houve efeito significativo $(p>0,05)$ para o atributo textura. Foi observado nas 3 semanas que todos os tratamentos permaneceram com a nota 7, valor correspondente a gostei moderadamente, atestando que não houve nenhuma alteração durante o armazenamento (Tabela 15).

O pimentão obteve médias entre 5 e 6, correspondentes ao limite de aceitabilidade para todos os tratamentos, apenas a amostra in natura recebeu nota 7 (gostei moderadamente), mesmo no último dia de armazenamento, onde houve uma considerável alteração na textura. (Tabela 15). O aumento da contagem de anaeróbios mesófilos (Tabela 14) pode ter contribuído para o amolecimento dos tecidos do pimentão, diminuindo a aceitabilidade do produto pelo provador.

A relação entre as características sensoriais e microbiológicas em alcachofras minimamente processadas e embaladas em filmes de permeabilidade variável ao vapor d'água, foi pesquisada por Gimenez et al. (2003). Para a maioria dos produtos ensaiados nenhuma correspondência foi encontrada entre o crescimento bacteriano e a aparência. Porém, nas embalagens onde a atmosfera de equilíbrio foi claramente anaeróbica, a contagem microbiana esteve abaixo da permitida pela legislação, no entanto, a perda da qualidade sensorial foi rápida.

Para a salada mista, todas as amostras receberam notas de 7 a 8 pelos provadores, valores correspondentes a gostei moderadamente a gostei muito, durante 7, 14 e 21 dias (Tabela 15). 
Di Pentima et al. (1996) estudando o comportamento de brócoli, espinafre e aspargos minimamente processados embalados sob diferentes tipos de embalagens e armazenados a $34^{\circ} \mathrm{C}$, não observaram diferença na textura de nenhum dos três produtos, obtendo notas equivalentes a "muito bom" no $8^{\circ}$ dia de armazenamento.

A textura e a microestrutura de maçãs do cultivar Golden estocadas sob atmosfera modificada, por várias semanas, sob ambiente onde se restringiu 0 oxigênio, foram analisadas por Soliva-Fortuny et al. (2003). Atmosfera com $100 \%$ de $\mathrm{N}_{2}$ e embalagens com permeabilidade de $15 \mathrm{~cm}^{3} \quad \mathrm{O}_{2} / \mathrm{m}^{2} / 24 \mathrm{~h}$ preservaram a estrutura celular de sofrer colapso, sendo, portanto, a condição ideal para manter a textura original de maçãs.

Tabela 15. Textura em cenoura, pimentão e salada mista minimamente processados, embalados sob ar atmosférico, vácuo e atmosfera modificada, armazenados sob refrigeração a $1^{\circ} \mathrm{C} \pm 1^{\circ} \mathrm{C}$.

\begin{tabular}{|c|c|c|c|c|c|c|}
\hline \multirow{3}{*}{ Produtos } & \multirow{3}{*}{ Tratamentos } & \multicolumn{4}{|c|}{ Textura (notas) } & \multirow{3}{*}{ Médias } \\
\hline & & \multicolumn{4}{|c|}{ Dias } & \\
\hline & & 1 & 7 & 14 & 21 & \\
\hline \multirow{4}{*}{ Cenoura } & $\mathrm{Ar}$ & 7,33 & 6,95 & 6,75 & 7,04 & $7,02 \mathrm{a}$ \\
\hline & Vácuo & 7,37 & 6,83 & 6,66 & 6,79 & $6,91 \mathrm{a}$ \\
\hline & Atm & 6,70 & 7,66 & 6,70 & 6,87 & $6,98 \mathrm{a}$ \\
\hline & Médias & $7,13 \mathrm{~A}$ & $7,15 \mathrm{~A}$ & $6,70 \mathrm{~A}$ & $6,90 \mathrm{~A}$ & \\
\hline \multirow{5}{*}{ Pimentão } & Ar & 6,33 & 6,09 & 5,61 & 5,76 & $5,95 \quad b$ \\
\hline & Vácuo & 6,23 & 6,28 & 6,57 & 3,66 & $5,69 \mathrm{~b}$ \\
\hline & Atm & 6,14 & 6,09 & 6,90 & 4,66 & $5,95 \quad b$ \\
\hline & In natura & 7,23 & 6.71 & 7,14 & 6,47 & $6,89 a$ \\
\hline & Médias & $6,48 \mathrm{~A}$ & $6,29 \mathrm{~A}$ & $6,56 \mathrm{~A}$ & $5,14 \mathrm{~B}$ & \\
\hline \multirow{4}{*}{$\begin{array}{l}\text { Salada } \\
\text { mista }\end{array}$} & $\mathrm{Ar}$ & 8,60 & 8,00 & 8,30 & 7,10 & $8,00 \mathrm{a}$ \\
\hline & Vácuo & 7,80 & 8,40 & 7,50 & 8,00 & $7,93 a$ \\
\hline & Atm & 8,60 & 8,30 & 8,10 & 8,50 & $8,38 \mathrm{a}$ \\
\hline & Médias & $8,33 \mathrm{~A}$ & $8,23 \mathrm{~A}$ & $7,97 \mathrm{~A}$ & $7,87 \mathrm{~A}$ & \\
\hline
\end{tabular}

Nota: Valores seguidos com a mesma letra maiúscula, dentro da mesma linha, e com a mesma letra minúscula, dentro da mesma subcoluna, não diferem entre si estatisticamente $(p<0,05)$. 


\subsubsection{Sabor}

Em decorrência da atividade respiratória em vegetais minimamente processados, há decréscimo nas reservas energéticas dos tecidos. Os principais substratos utilizados na respiração são os açúcares livres e ácidos orgânicos e a redução na concentração dos mesmos reflete nas condições de sabor do produto (Chitarra, 1999).

As notas atribuídas para o sabor da cenoura minimamente processada mantiveram-se entre os valores 6 e 7, ou seja, gostei ligeiramente e gostei moderadamente, respectivamente, para os diferentes tratamentos, em todo o período de armazenamento (Tabela 16). O sabor está relacionado com o pH, acidez titulável, sólidos solúveis totais e açúcares totais e nesta pesquisa, as variações ocorridas nas análises físico-químicas foram mínimas, não sendo suficientes para alterar o sabor das cenouras. Em pesquisa realizada por Priepke et al. (1976), com cenouras cortadas, embaladas em filmes de baixa permeabilidade, constatou-se diminuição de 8 para 3 nas notas atribuídas ao sabor, durante armazenamento refrigerado a $4^{\circ} \mathrm{C}$.

Para o pimentão minimamente processado, todos os tratamentos até 0 $14^{\circ}$ dia de armazenamento, obtiveram médias próximas a 6 , correspondente a "gostei ligeiramente" (Tabela 16).

Para a salada mista, não ocorreram variações significativas para este atributo, todos os tratamentos receberam notas que permaneceram na escala 7 a 8, valores correspondentes a gostei moderadamente a gostei muito, durante todo o período de armazenamento (Tabela 16). 
Tabela 16. Sabor em cenoura, pimentão e salada mista minimamente processados, embalados sob ar atmosférico, vácuo e atmosfera modificada, armazenados sob refrigeração a $1^{\circ} \mathrm{C} \pm 1^{\circ} \mathrm{C}$.

\begin{tabular}{|c|c|c|c|c|c|c|}
\hline \multirow{3}{*}{ Produtos } & \multirow{3}{*}{ Tratamentos } & \multicolumn{4}{|c|}{ Sabor (notas) } & \multirow{3}{*}{ Médias } \\
\hline & & \multicolumn{4}{|c|}{ Dias } & \\
\hline & & 1 & 7 & 14 & 21 & \\
\hline \multirow{4}{*}{ Cenoura } & $\mathrm{Ar}$ & 7,12 & 6,29 & 6,79 & 6,50 & $6,68 \mathrm{a}$ \\
\hline & Vácuo & 7,25 & 6,54 & 5,95 & 6,66 & $6,60 \mathrm{a}$ \\
\hline & Atm & 6,50 & 7,29 & 6,45 & 6,33 & $6,64 \mathrm{a}$ \\
\hline & Médias & $6,96 \mathrm{~A}$ & $6,71 \mathrm{~A}$ & $6,40 \mathrm{~A}$ & $6,50 \mathrm{~A}$ & \\
\hline \multirow{5}{*}{ Pimentão } & $\mathrm{Ar}$ & 5,33 & 4,81 & 5,43 & --- & $5,19 \quad b$ \\
\hline & Vácuo & 5,90 & 5,90 & 5,95 & --- & $5,92 \quad b$ \\
\hline & Atm & 5,57 & 5,14 & 5,47 & --- & $5,39 \mathrm{~b}$ \\
\hline & In natura & 6,57 & 6,28 & 6,71 & --- & $6,52 \mathrm{a}$ \\
\hline & Médias & $5,84 \mathrm{~A}$ & $5,53 \mathrm{~A}$ & $5,89 \mathrm{~A}$ & --- & \\
\hline \multirow{4}{*}{$\begin{array}{l}\text { Salada } \\
\text { mista }\end{array}$} & $\mathrm{Ar}$ & 8,30 & 8,10 & 7,50 & 7,50 & $7,85 a$ \\
\hline & Vácuo & 8,50 & 8,40 & 7,20 & 7,70 & $7,95 a$ \\
\hline & Atm & 8,20 & 8,00 & 8,20 & 8,40 & $8,20 \mathrm{a}$ \\
\hline & Médias & $8,33 \mathrm{~A}$ & $8,17 \mathrm{~A}$ & $7,63 \mathrm{~A}$ & $7,87 \mathrm{~A}$ & \\
\hline
\end{tabular}

Nota: Valores seguidos com a mesma letra maiúscula, dentro da mesma linha, e com a mesma letra minúscula, dentro da mesma subcoluna, não diferem entre si estatisticamente $(p<0,05)$.

\subsubsection{Aroma e avaliação global}

Quanto ao aroma da cenoura minimamente processada, todos os tratamentos receberam notas acima de 5 pelos provadores, correspondente ao limite de aceitabilidade, mesmo no último período de armazenamento (Tabela 17), concordando com Izumi et al. (1996) os quais não encontraram odor desagradável em cenouras cortadas em fatias e tiras durante o armazenamento a $0^{\circ} \mathrm{C}$ e $5^{\circ} \mathrm{C}$, sob atmosfera de $0,5 \%$ de $\mathrm{O}_{2}$ e $10 \%$ de $\mathrm{CO}_{2}$. A avaliação global não obteve grandes variações durante o período para os diversos tratamentos, com notas recebidas permanecendo entre 6 a 7, gostei ligeiramente a gostei moderadamente, respectivamente (Tabela 18). O mesmo ocorreu com as pesquisas de Abdul-Raouf et al. (1993), onde a aparência geral de cenouras 
minimamente processadas manteve-se inalterada durante 14 dias, quando embaladas sob atmosfera modificada e armazenadas a $5^{\circ} \mathrm{C}$.

Para os pimentões minimamente processados, embora diferindo estatisticamente $(p \leq 0,05)$, foi observado para 0 aroma, que as notas permaneceram estáveis durante todo o período de armazenamento (Tabela 17). As amostras embaladas sob ar atmosférico mostraram-se inferiores æ̀ demais, encontrando-se na escala 4 (desgostei ligeiramente) durante todo o tempo. Características citadas pelos provadores como odores estranhos e de plástico, colaboraram para este resultado.

Tabela 17. Aroma em cenoura, pimentão e salada mista minimamente processados, embalados sob ar atmosférico, vácuo e atmosfera modificada, armazenados sob refrigeração a $1^{\circ} \mathrm{C} \pm 1^{\circ} \mathrm{C}$.

\begin{tabular}{|c|c|c|c|c|c|c|}
\hline \multirow{3}{*}{ Produtos } & \multirow{3}{*}{ Tratamentos } & \multicolumn{4}{|c|}{ Aroma (notas) } & \multirow{3}{*}{ Médias } \\
\hline & & \multicolumn{4}{|c|}{ Dias } & \\
\hline & & 1 & 7 & 14 & 21 & \\
\hline \multirow{4}{*}{ Cenoura } & $\mathrm{Ar}$ & 6,29 & 5,70 & 6,12 & 5,37 & $5,87 a$ \\
\hline & Vácuo & 6,58 & 6,08 & 5,66 & 6,25 & $6,14 a$ \\
\hline & Atm & 5,33 & 6,70 & 6,16 & 6,50 & \multirow{2}{*}{$6,17 \mathrm{a}$} \\
\hline & Médias & $6,07 \mathrm{~A}$ & $6,16 \mathrm{~A}$ & $5,98 \mathrm{~A}$ & $6,04 \mathrm{~A}$ & \\
\hline \multirow{5}{*}{ Pimentão } & $\mathrm{Ar}$ & 4,47 & 4,66 & 4,04 & 5,19 & $4,59 \quad b$ \\
\hline & Vácuo & 5,00 & 5,85 & 5,80 & 3,95 & $5,15 \quad b$ \\
\hline & Atm & 5,28 & 5,57 & 5,09 & 4,62 & $5,14 \quad b$ \\
\hline & In natura & 6,71 & 6,80 & 5,95 & 5,95 & \multirow{2}{*}{$6,35 \mathrm{a}$} \\
\hline & Médias & $5,37 \mathrm{AB}$ & $5,72 \mathrm{~A}$ & $5,22 \mathrm{AB}$ & $4,93 \mathrm{~B}$ & \\
\hline \multirow{4}{*}{$\begin{array}{l}\text { Salada } \\
\text { mista }\end{array}$} & $\mathrm{Ar}$ & 8,40 & 7,90 & 8,30 & 7,70 & \multirow{4}{*}{$\begin{array}{l}8,08 \mathrm{a} \\
7,73 \mathrm{a} \\
7,95 \mathrm{a}\end{array}$} \\
\hline & Vácuo & 8,40 & 7,80 & 7,30 & 7,40 & \\
\hline & Atm & 8,10 & 8,30 & 7,70 & 7,70 & \\
\hline & Médias & $8,30 \mathrm{~A}$ & $8,00 \mathrm{~A}$ & $7,77 \mathrm{~A}$ & $7,60 \mathrm{~A}$ & \\
\hline
\end{tabular}

Nota: Valores seguidos com a mesma letra maiúscula, dentro da mesma linha, e com a mesma letra minúscula, dentro da mesma subcoluna, não diferem entre si estatisticamente $(p<0,05)$.

Para a salada mista, não ocorreram variações significativas para o aroma e avaliação global, todos os tratamentos receberam notas que permaneceram na escala 7 a 8 , valores correspondentes a gostei moderadamente e gostei 
muito, durante todo o período de armazenamento (Tabelas 17 e 18). Di Pentima et al. (1996), não encontraram diferenças significativas nas análises de aparência geral de brócolis, espinafre e aspargos minimamente processados, apenas a ocorrência de desenvolvimento de odor desagradável em filmes de menor permeabilidade.

Tabela 18. Avaliação global de cenoura, pimentão e salada mista minimamente processados, embalados sob ar atmosférico, vácuo e atmosfera modificada, armazenados sob refrigeração a $1^{\circ} \mathrm{C} \pm 1^{\circ} \mathrm{C}$.

\begin{tabular}{|c|c|c|c|c|c|c|}
\hline \multirow{3}{*}{ Produtos } & \multirow{3}{*}{ Tratamentos } & \multicolumn{4}{|c|}{ Avaliação global (notas) } & \multirow{3}{*}{ Médias } \\
\hline & & \multicolumn{4}{|c|}{ Dias } & \\
\hline & & 1 & 7 & 14 & 21 & \\
\hline \multirow{4}{*}{ Cenoura } & $\mathrm{Ar}$ & 7,08 & 6,08 & 6,20 & 5,54 & $6,23 a$ \\
\hline & Vácuo & 6,83 & 6,20 & 5,91 & 6,04 & $6,25 a$ \\
\hline & Atm & 5,87 & 6,79 & 6,12 & 5,79 & $6,14 \mathrm{a}$ \\
\hline & Médias & $6,59 \mathrm{~A}$ & $6,36 \mathrm{~A}$ & $6,08 \mathrm{~A}$ & $5,79 \mathrm{~A}$ & \\
\hline & $\mathrm{Ar}$ & 5,38 & 4,85 & 5,23 & 4,90 & $5,09 \quad b$ \\
\hline \multirow{3}{*}{ Pimentão } & Vácuo & 5,61 & 6,28 & 6,04 & 4,09 & $5,51 \quad b$ \\
\hline & Atm & 5,38 & 5,38 & 6,66 & 4,09 & $5,38 \quad b$ \\
\hline & In natura & 6,90 & 6,66 & 7,09 & 6,14 & $6,70 \mathrm{a}$ \\
\hline \multirow{5}{*}{$\begin{array}{l}\text { Salada } \\
\text { mista }\end{array}$} & Médias & $5,82 \mathrm{~A}$ & $5,79 A$ & $6,26 \mathrm{~A}$ & $4,81 \mathrm{~B}$ & \\
\hline & & 8,30 & 7,80 & 8,30 & 7,40 & $7,95 a$ \\
\hline & Vácuo & 8,00 & 8,00 & 7,60 & 7,40 & $7,75 \mathrm{a}$ \\
\hline & Atm & 8,30 & 8,10 & 7,80 & 8,00 & $8,05 a$ \\
\hline & Médias & $8,20 \mathrm{~A}$ & 7,97 A & $7,90 \mathrm{~A}$ & $7,60 \mathrm{~A}$ & \\
\hline
\end{tabular}

Nota: Valores seguidos com a mesma letra maiúscula, dentro da mesma linha, e com a mesma letra minúscula, dentro da mesma subcoluna, não diferem entre si estatisticamente $(p<0,05)$.

\subsubsection{Cor}

Para a cenoura minimamente processada, houve efeito significativo $(p \leq 0,05)$ somente do período de armazenamento sobre o atributo cor. As notas atribuídas variaram durante o período de armazenamento de 5 a 6, ou seja, não gostei nem desgostei a gostei ligeiramente (Tabela 19). Foi observado um esbranquiçamento dos cubos de cenoura desde o primeiro até o último dia de 
armazenamento; o que alguns autores denominam de white blushe atestam ser resultado da desidratação das células superficiais, devido aos danos causados pelo processamento (Tatsumi et al., 1991, 1993); para outros autores o fato se deve à formação de lignina na superfície do corte (Bolin \& Huxsoll, 1991) ou ambos ocorrendo concomitantemente (Cisneros-Zevallos et al., 1995).

Para o pimentão minimamente processado, apenas os resultados obtidos para a amostra in natura, diferiram, estatisticamente, dos demais tratamentos, obtendo nota 7 (gostei moderadamente). As amostras embaladas sob vácuo obtiveram média próxima a 6 (gostei ligeiramente), mostrando-se superior à atmosfera modificada e ar atmosférico que permaneceram ao longo do período de armazenamento com a nota 5 (Tabela 19).

Freire et al. (1999), também não encontraram diferenças significativas na cor de alface minimamente processada, embaladas em sacos plásticos do tipo BOPP/PEBD (polipropileno biorientado/polietileno de baixa densidade) e armazenadas sob temperatura de refrigeração de $2^{\circ} \mathrm{C}$.

Para a salada mista, o período e os tratamentos tiveram efeito sobre a variável cor. As amostras embaladas sob atmosfera modificada obtiveram média 8 (gostei muito), nota superior aos demais tratamentos. Durante 0 período de armazenamento, observou-se uma diminuição nas notas atribuídas, de 8 para 6, nas amostras embaladas a vácuo. Esse fato ocorreu em função do escurecimento ocorrido na vagem, comprometendo o produto, uma vez que a batata pouco se alterou em relação à cor, mesmo na última semana de armazenamento (Tabela 19). O’Beirne \& Ballantyne, (1987), observaram em batata minimamente processada tratada com 10\% de ácido ascórbico e armazenadas a $5^{\circ} \mathrm{C}$, inibição do escurecimento enzimático por uma semana, quando embaladas sob atmosfera modificada com $5 \%$ de $\mathrm{O}_{2}$ e $10 \%$ de $\mathrm{CO}_{2}$, e por duas semanas quando embaladas a vácuo.

O tratamento com ácido ascórbico e $10 \%$ de $\mathrm{KCl}$ a $2 \%$ tem a habilidade de preservar a descoloração, sem afetar o sabor de peras (Pyrus communis), conforme observado por Chen et al. (2003). A imersão das peras na solução 
citada, por 30 seg, foi suficiente para manter a coloração das frutas durante 14 dias, sob refrigeração entre $-1,1$ e $1,7^{\circ} \mathrm{C}$.

Tabela 19. Cor de cenoura, pimentão e salada mista minimamente processados, embalados sob ar atmosférico, vácuo e atmosfera modificada, armazenados sob refrigeração a $1^{\circ} \mathrm{C} \pm 1^{\circ} \mathrm{C}$.

\begin{tabular}{|c|c|c|c|c|c|c|}
\hline \multirow{3}{*}{ Produtos } & \multirow{3}{*}{ Tratamentos } & \multicolumn{4}{|c|}{ Cor (notas) } & \multirow{3}{*}{ Médias } \\
\hline & & \multicolumn{4}{|c|}{ Dias } & \\
\hline & & 1 & 7 & 14 & 21 & \\
\hline \multirow{3}{*}{ Cenoura } & $\begin{array}{l}\text { Ar } \\
\text { Vácuo }\end{array}$ & $\begin{array}{l}6,66 \\
641\end{array}$ & $\begin{array}{l}5,12 \\
5,54\end{array}$ & $\begin{array}{l}5,45 \\
5,75\end{array}$ & $\begin{array}{l}4,79 \\
5,33\end{array}$ & $\begin{array}{l}5,51 \mathrm{a} \\
5,76 \mathrm{a}\end{array}$ \\
\hline & Atm & 5,12 & 6.04 & 5,62 & 5,16 & \multirow{2}{*}{$5,49 a$} \\
\hline & Médias & $6,06 \mathrm{~A}$ & $5,57 \mathrm{AB}$ & $5,61 \mathrm{AB}$ & $5,09 \mathrm{~B}$ & \\
\hline \multirow{3}{*}{ Pimentão } & $\begin{array}{l}\text { Ar } \\
\text { Vácuo }\end{array}$ & $\begin{array}{l}5,81 \\
5,71\end{array}$ & $\begin{array}{l}4,76 \\
6,04\end{array}$ & $\begin{array}{l}5,09 \\
6,61\end{array}$ & $\begin{array}{l}5,14 \\
4,80\end{array}$ & $\begin{array}{ll}5,20 & b \\
5,79 & b\end{array}$ \\
\hline & Atm & 5,57 & 5,47 & 6,00 & 5,28 & $5,58 \quad b$ \\
\hline & In natura & 8,19 & 7,38 & 6,76 & 7,47 & $7,45 a$ \\
\hline \multirow{5}{*}{$\begin{array}{l}\text { Salada } \\
\text { mista }\end{array}$} & Médias & 6,32 A & $5,91 \mathrm{~A}$ & $6,12 \mathrm{~A}$ & $5,67 \mathrm{~A}$ & \multirow{5}{*}{$\begin{array}{l}6,93 \quad b \\
6,78 \quad b \\
7,80 a\end{array}$} \\
\hline & $\mathrm{Ar}$ & 7,00 & 7,80 & 6,90 & 6,00 & \\
\hline & Vácuo & 8,20 & 5,70 & 6,90 & 6,30 & \\
\hline & Atm & 8,80 & 8,30 & 6,30 & 7,80 & \\
\hline & Médias & $8,00 \mathrm{~A}$ & $7,27 \mathrm{AB}$ & $6,70 \mathrm{~B}$ & $6,70 \mathrm{~B}$ & \\
\hline
\end{tabular}

Nota: Valores seguidos com a mesma letra maiúscula, dentro da mesma linha, e com a mesma letra minúscula, dentro da mesma subcoluna, não diferem entre si estatisticamente $(p<0,05)$. 


\section{CONCLUSÕES}

Por meio dos resultados das análises físico-químicas, nutricionais, microbiológicas e sensoriais dos três produtos, pôde-se notar semelhança entre os tratamentos realizados.

Cenoura e salada mista, embaladas sob ar atmosférico, vácuo e atmosfera modificada e armazenadas sob temperatura de refrigeração de $1^{\circ} \mathrm{C}$, apresentaram baixa proliferação microbiana, mostrando a importância dos métodos combinados de conservação para obtenção de produtos seguros com maior vida útil.

Para a cenoura e salada mista minimamente processadas, não foram constatados coliformes totais e fecais, anaeróbios mesófilos e Salmonella em nenhum dos tratamentos. A presença de anaeróbios mesófilos e coliformes totais, foi constatada em pimentões minimamente processados.

$\mathrm{Na}$ cenoura, salada mista e pimentão minimamente processados foram constatados, em todos os tratamentos, microrganismos psicrotróficos.

A vitamina $C$ não foi afetada pelo processamento mínimo em nenhum dos tratamentos e dos períodos de armazenamento, nos três produtos.

Os teores de $\beta$-caroteno se mantiveram constantes em cenoura e salada mista. No pimentão, após a primeira semana de armazenamento, ocorreu um decréscimo, permanecendo praticamente inalterados ao longo do período de armazenamento.

O processamento mínimo não alterou o teor de nenhum dos minerais analisados em salada mista. $O$ fósforo, magnésio, cobre, ferro, manganês e 
zinco, para a cenoura e o cálcio, magnésio e manganês, para o pimentão, sofreram ligeiras variações durante o período de armazenamento.

Quanto àanálise sensorial, as médias das notas para a cenoura e salada mista, foram satisfatórios durante 7, 14 e 21 dias de armazenamento para todos os tratamentos. O pimentão embalado sob ar atmosférico ficou comprometido, sensorialmente, após 7 dias de armazenamento.

A variação na acidez titulável e no $\mathrm{pH}$, não afetou o sabor de cenouras minimamente processadas. Em pimentão o sabor e a textura ficaram comprometidos na última semana de armazenamento.

A vida útil, entendida sob os aspectos microbiológicos, sensoriais e nutricionais (vitaminas e minerais) pode ser estabelecida em 21 dias sob refrigeração para cenoura e salada mista submetidas ao processamento mínimo. 


\section{REFERÊNCIAS BIBLIOGRÁFICAS}

ABDUL-RAOUF, U.M.; BEUCHAT, L.R.; AMMAR, M.S. Survival and growth of Echerichia coli $\mathrm{O} 157: \mathrm{H} 7$ on salad vegetables. Applied and Environmental Microbiology, v.59, n.7, p.1999-2006, 1993.

ADAMS, M.R.; HARTLEY, A.D.; COX, L.J. Factors affecting the eficacy of washing procedures used in the production of prepared salads. Food Microbiology, v.6, p.69-77, 1989.

AGÊNCIA NACIONAL DE VIGILÂNCIA SANITÁRIA - ANVISA. Resolução RDC n⿳12, de 12 de janeiro de 2001. http:/www.anvisa.gov.br/legis/resol/ 12_01rdc.htm (10 set. 2001)

AGÊNCIA NACIONAL DE VIGILÂNCIA SANITÁRIA - ANVISA. Resolução RDC n40, de 21 de março de 2001. http:/www.anvisa.gov.br/legis/resol/ 40_01rdc.htm (11 dez. 2002)

ALMEIDA, M.E.M. de. Estudo de interações entre o emprego de compostos químicos com o tratamento térmico no controle da atividade da polifenol oxidase em frutas e hortaliças. Piracicaba, 1991. 112p. Dissertação (Mestrado) - Escola Superior de Agricultura "Luiz de Queiroz", Universidade de São Paulo. 
APPCC na qualidade e segurança microbiológica de alimentos: análises de perigos e pontos críticos para garantir a qualidade e a segurança microbiológica de alimentos. São Paulo: Livraria Varela, 1997. 377p.

ARAÚJO, F.M.M.C.; VILAS BOAS, E.V. de B.; PRADO, M.E.T. et al. Influência do hipoclorito de sódio sobre a qualidade de melões minimamente processados. In: ENCONTRO NACIONAL SOBRE PROCESSAMENTO MÍNIMO DE FRUTAS E HORTALIÇAS, 2., Viçosa, 2000. Resumos. Viçosa: UFV, 2000. p.22.

ARIHARA, K.; CASSENS, R.G.; LUCHANSKY, J.B. Characterization of bacteriocins from Enterococcus faecium with activity against Listeria monocytogenes. International Journal of Food Microbiology, v.19, p.123134, 1993.

ASSOCIATION OF OFFICIAL AGRICULTURAL CHEMISTS - AOAC. Official methods of analysis. 16.ed. Arlington: AOAC, 1995. v.2.

BABIC, I.; HILBERT, G.; NGUYEN-THE, C.; GUIRAUD, J. The yeast flora of stored ready-to-use carrots and their role in spoilage. International Journal of Food Science and Technology, v.27, p.473-487, 1992.

BAKER, R.C.; QURESHI, R.A.; HOTCHKISS. J.H. Effect of an elevated level of carbon dioxide containing atmosphere on the growth of spoilage and pathogenic bacteria at 2,7 , and $13^{\circ} \mathrm{C}$. Poultry Science, v.12, p.729-737, 1986.

BARTH, M.M.; PERRY, A.K.; SCHMIDT, S.J.; KLEIN, B.P. Misting effects on ascorbic and retention in broccoli durig cabinet display. Journal of Food Science, v.55, p.1187-1188, 1990. 
BENEDETTI, B.C.; GOLINELLI, C.C.; SARANTÓPOULOS, C.I.G.L. Avaliação de pimentão minimamente processado em rodelas e tiras, armazenado nas temperaturas de 5 e $10^{\circ} \mathrm{C}$. In: CONGRESSO BRASILEIRO DE CIÊNCIA E TECNOLOGIA DE ALIMENTOS, 18., Porto Alegre, 2002. Anais. Porto Alegre: SBCTA, 2002. p.1241-1245.

BENNIK, M.H.J.; PEPPELENBOS, H.W.; NGUYEN-THE, C. et al. Microbiology of minimally processed, modified-atmosphere packaged chicory endive. Postharvest Biology and Technology, v.9, p.209-221, 1996.

BENNIK, M.H.J.; VORSTMAN, W.; SMID, E.; GORRIS, L. The influence of oxygen and carbon dioxide on the growth of prevalent Enterobacteriaceae and Pseudomonas species isolated from fresh and controlled-atmospherestored vegetables. Food Microbiology, v.15, p.459-469, 1998.

BERRANG, M.E.; BRACKETT, R.E.; BEUCHAT, L.R. Growth of Aeromonas hydrophila on fresh vegetables stored under a controlled atmosphere. Applied and Environmental Microbiology, v.55, p.2167-2171, 1989.

BERRANG, M.E.; BRACKETT, R.E.; BEUCHAT, L.R. Microbial, color and textural qualities of fresh asparagus, broccoli, and cauliflower stored under controlled atmosphere. Journal of Food Protection, v.53, p.391-395, 1990.

BEUCHAT, L.R.; BRACKETT, R.E. Inhibitory effects of raw carrots on Listeria monocytogenes. Applied and Environmental Microbiology, v.56, n.6, p.1734-1742, 1990.

BEUCHAT, L.R. Pathogenic microorganisms associated with fresh produce. Journal of Food Protection, v.59, p.204-216, 1996. 
BEUCHAT, L.R.; NAIL, B.V.; ADLER, B.B.; CLAVERO, M.R.S. Efficacy of spray application of chlorinated water in killing pathogenic bacteria on raw, apples, tomatoes, and letucce. Journal of Food Protection, v.61, n.10, p.13051311, 1998.

BEZERRA, V.S. Alterações na composição química e cocção de raízes de mandioca (Manihot esculenta Crantz) minimamente processadas. Lavras, 2000. 92p. Tese (M.S.) - Universidade Federal de Lavras.

BITTENCOURT, M.T.; VANETTI, M.C.D.; PUSCHMANN, R. Atividade microbiana em couve minimamente processada. In: ENCONTRO NACIONAL SOBRE PROCESSAMENTO MÍNIMO DE FRUTAS E HORTALIÇAS, 2., Viçosa, 2000. Resumos. Viçosa: UFV, 2000. p.42.

BOLIN, H.R.; HUXSOLL, C.C. Control of minimally processed carrot (Daucus carota) surface discoloration caused by abrasion peeling. Journal of Food Science, v.56, n.2, p.416-418, 1991.

BRACKETT, R.E. Growth and survival of $Y$. enterocolitica acid $\mathrm{pH}$. International Journal of Food Microbiology, v.3, p.243-251, 1986.

BRACKETT, R.E. Microbiological consequences of minimally processed fruits and vegetables. Food Quality, v.10, p.195-206, 1987.

BRACKETT, R.E. Shelf stability and safety of fresh produce as influenced by sanitation and disinfection. Journal of Food Protection, v.55, n.10, p.808814, 1992. 
BRACKETT, R.E. Microbiological spoilage and pathogens in minimally processed refrigerated fruits and vegetables. In: WILEY, R.C. Minimally processed refrigerated fruits and vegetables. New York: Chapman \& Hall, 1994. cap.1, p.269-312.

BRASIL. Ministério da Saúde. Secretaria de Vigilância Sanitária. Portaria no 451, de 19 de setembro de 1997. In: ASSOCIAÇÃO BRASILEIRA DAS INDÚSTRIAS DE ALIMENTOS. Compêndio de legislação de alimentos. São Paulo: ABIA, 1997. v.1A.

BRECHT, J.K. Physiology of lightly processed fruits and vegetables. HortScience, v.30, n.1, p.18-21, 1995.

CARLIN, F.; NGUYEN-THE, C.; CHAMBROY, Y. et al. Effects of controlled atmospheres on microbial spoilage, eletrolyte leakage and sugar content on fresh, read-to-use grated carrots. International Journal of Food Science and Technology, v.25, p.110-119, 1990.

CARVALHO, A.V.; LIMA, L.C.O. Avaliação da qualidade de kiwis minimamente processados submetidos ao tratamento com ácido ascórbico, ácido cítrico e cloreto de cálcio. In: CONGRESSO BRASILEIRO DE CIÊNCIA E TECNOLOGIA DE ALIMENTOS, 17., Fortaleza, 2000. Resumos. Fortaleza: SBCTA, 2000. p.8.25.

CHAIM, N.A.; VIANNA, R.P. de T.; GALEAZZI, A.M. Utilização de excedentes de comercialização da CEASA - Campinas para implementação da merenda escolar em Campinas. In: CONGRESSO BRASILEIRO DE CIÊNCIA E TECNOLOGIA DE ALIMENTOS, 15., Poços de Caldas, 1996. Resumos. Poços de Caldas: SBCTA, 1996. p.105. 
CHEFTEL, J.C.; CHEFTEL, H. Introdución a la bioquimica de los alimentos. Zaragoza: Acribia, 1983. 2v.

CHEN, P.M.; VARGA, D.M.; SEAVERT, C.F. Developing a value-added freshcut ‘D’Anjou' pear product. Horttechnology, v.13, n.2, p.314-320, 2003.

CHITARRA, M.I.F. Processamento mínimo de frutos e hortaliças. Viçosa: UFV, 1998. 88p.

CHITARRA, M.I.F. Processamento mínimo de frutas e hortaliças. Tecnologia e Treinamento Agropecuário, v.2, n.9, p.7, 1999.

CINEROS-ZEVALLOS, L.; SALTVEIT, M.E.; KROCHTA, J.M. Mechanism of surface white discoloration of peeled (minimally processed) carrots during storage. Journal of Food Science, v.60, n.2, p.320-324, 1995.

CUNHA, D.F. da.; CUNHA, S.F.C. da. Microminerais. In: DUTRA-DEOLIVEIRA, J.E.; MARCHINI, J.S. Ciências nutricionais. São Paulo: Sarvier, 1998. cap.9, p.141-166: Microminerais.

DI PENTIMA, J.H.; GÜEMES, D.R.; PIROVANI, M.E.; PIAGENTINI, A.M. Estudio del comportamiento de vegetables listos para usar, envasados con diferentes láminas plásticas. La Alimentación Latinoamericana, v.30, n.213, p.46-50, 1996.

DIXON, N.M.; KELL, D.B. The inhibition by $\mathrm{CO}_{2}$ of the growth and metabolism of microorganisms: a review. Journal of Applied Bacteriology, v.67, p.109136, 1989. 
DUTRA-DE-OLIVEIRA, J.E.; MARCHINI, J.S. Macrominerais. In: Ciências nutricionais. São Paulo: Sarvier, 1998. cap.8, p.133-140: Macromi nerais.

DYCHDALA, G.R. Chlorine and chlorine compounds. In: BLOCK, S.S.; BARKLEY, W.E. Desinfection, sterelization and preservation. 4.ed. Philadelphia: Lea \& Febiger, 1991. p.131-151.

FANTUZZI, E. Atividade microbiana em repolho (Brassica oleraceae cv. capitata) minimamente processado. Viçosa, 1999. 50p. Dissertação (M.S.) Universidade Federal de Viçosa.

FAO. Necesidades de vitamina A, hierro, folato y vitamina $\mathbf{B}_{\mathbf{1 2}}$. Roma, 1991. 124p. (Estudios FAO Alimentación y nutrición, 23)

FARBER, J.M. Microbiological aspects of modified-atmosphere packaging technology: a review. Journal of Food Protection, v.54, n.1, p.58-70, 1991.

FARBER, J.M.; PETERKIN, P.I. Listeria monocytogenes, a foodborne pathogen. Microbiology Reviews, v.55, p.476-511, 1991.

FERREIRA, K.S.; GOMES, J.C. A desnutrição mineral na dieta básica do Brasil e suas conseqüências para a saúde da população. In: CONGRESSO BRASILEIRO DE CIÊNCIA E TECNOLOGIA DE ALIMENTOS, 15., Poços de Caldas, 1996. Resumos. Poços de Caldas: SBCTA, 1996. p.105.

FERREIRA, M.A . Um mercado fértil para o Brasil. Frutas e Legumes, v.1, n.3, p.8-10, 2000.

FLEET, G. Spoilage yeasts. Critical Review Biotechnology, v.12, p.1-44, 1992. 
FRANCIS, G.A.; O'BEIRNE, D. Effects of gas atmosphere, antimicrobial dip and temperature on the fate of $L$. innocua and $L$. monocytogenes on minimally processed lettuce. International Journal of Food Science and Technology, v.32, p.141-151, 1997.

FRANCIS, G.A.; THOMAS, C.; O'BEIRNE, D. The microbiological safety of minimally processed vegetables. . International Journal of Food Science and Technology, v.34, p.1-22, 1999.

FRANCO, G. Tabela de composição química dos alimentos. 9.ed. São Paulo: Atheneu, 1999. 307p.

FREIRE JUNIOR, M. Efeito da temperatura de armazenamento e influência da atmosfera modificada na qualidade do alface hidropônico cv. Regina minimamente processado. Lavras, 1999. 120p. Tese (Doutorado) Universidade Federal de Lavras.

FURLANI, A.M.C.; FURLANI, P.R.; BATAGLIA, O.C.; HIROCE, R.; GALLO, J.R. Composição centesimal de diversas hortaliças. Bragantia, v.37, n.5, p.3334, 1978.

GARCÍA-GIMENO, R.M.; SANCHEZ-POZO, M.D. et al. Behaviour of Aeromonas hydrophila in vegetable salads stored under modified atmosphere at 4 and $15^{\circ} \mathrm{C}$. Food Microbiology, v.13, p.369-374, 1996.

GARCÍA-GIMENO, R.M.; ZURERA-COSANO, G. Determination of ready-to-eat vegetable salad shelf-life. International Journal of Food Microbiology, v.36, p.31-38, 1997. 
GARG, N.; CHUREY, J.J.; SPLITTSTOESSER, D.F. Effect of processing conditions on the microflora of fresh-cut vegetables. Journal of Food Protection, v.53, p.701-703, 1990.

GIL, M.I.; CONESA, M.A.; ARTÉS, F. Quality changes in fresh-cut tomato as affected by modified atmosphere packaging. Postharvest Biology and Technology, v.25, p.199-207, 2002.

GIMENEZ M.; OLARTE, C.; SANZ. S.; LOMAS. C.; ECHAVARRI, J.F.; AYALA, F. Relation between spoilage and microbiological quality in minimally processed artichoke packaged. Food Microbiology, v.20, n.2, p.231-242, 2003.

GUILLAND, J.-C. ; LEQUEU, B. As vitaminas: do rutriente ao medicamento. São Paulo: Livraria Santos, 1995. 357p.

HENDLER, S.S. A enciclopédia de vitaminas e minerais. 8.ed. Rio de Janeiro: Campus, 1994. 576p.

HONÓRIO, S.L. Tecnologia pós-colheita na redução das perdas. In: AMAYAFARFAN, J.; FARIA, J.A.F.; SALAY, E. Encontro municipal sobre o desperdício de alimentos. Campinas: Unicamp, 1993. p.44-53.

HUDSON, J.A.; DELACY, K.M. Incidence of motile aeromonads in New Zealand retail foods. Journal of Food Protection, v.54, p.696-699, 1991.

HUNT, J.R. Ascorbic acid: effect on ongoing iron absortion and status in iron depleted young women. American Journal of Clinical Nutrition, v.51, p.649-655, 1990. 
HURST, W.C. Sanitation of lightly processed fruits and vegetables. Horticultural Science, v.30, p.22-24, 1995.

HUSSEIN, A.; ODUMERU, J.A.; AYANBADEJO, T. et al. Effects of processing and packaging on vitamin $C$ and $\beta$-caroteno content of ready-to-use (RTU) vegetables. Food Research International, v.33, p.131-136, 2000.

HUXSOLL, C.C.; BOLEN, H.R. Processing and distribuition alternatives for minimally processed fruits and vegetables. Food Technology, v.43, n.2, p.124-128, 1989.

INSTITUTO BRASILEIRO DE GEOGRAFIA E ESTATÍSTICA. Tabelas de composição dos alimentos. Rio de Janeiro: IBGE, 1977. 202p. (Estudo Nacional da Despesa Familiar, 3)

INSTITUTO BRASILEIRO DE GEOGRAFIA E ESTATÍSTICA. Despesas das famílias. Rio de Janeiro: IBGE, 1978. 85p. (Estudo Nacional da Despesa Familiar, 3)

INTERNATIONAL COMMISION ON MICROBIOLOGICAL SPECIFICATIONS FOR FOODS. Ecologia microbiana de los alimentos. Zaragoza: Acribia, 1985. v.2, 1989p.

IZUMI, H.; WATADA, A.E.; KO, N.P.; DOUGLAS, W. Controlled atmosphere storage of carrot slices, sticks and shreds. Postharvest Biology and Technology, v.9, p.165-172, 1996. 
JACKSENS, L.; DEVLIEGHERE, F.; DEBEVERE, J. Temperature dependence of shelf-life as affected by microbial proliferation and sensory quality of equilibrium modified atmosphere package fresh produce. Postharvest Biology and Technology, v.26, p.59-73, 2002.

JAY, J. Microbiologia moderna de los alimentos. 3.ed. Zaragoza: Acribia, 1994. cap.11, p.299-343: Conservacion de alimentos com agentes quimicos.

JAYAS, D.S.; JEYAMKONDAN, S. Modified atmosphere storage of grains meats fruits and vegetables. Biosystems Engineering, v.82, n3, p.235251, 2002.

JUNQUEIRA, A.H.; LUENGO, R.F.A. Mercados diferenciados de hortaliças. Circular Técnica EMBRAPA, n.17, p.1-7, 1999.

KADER, A.A. Biochemical and physiological basis for effects of controlled and modified atmospheres on fruits and vegetables. Food Technology, v.40, n.5, p.99-104, 1986.

KADERA, A.A.; BEN-YEHOSHUAB, S. Effects of superatmospheric oxygen levels on postharvest physiology and quality of fresh fruits and vegetables. Postharvest Biology and Technology, v.20, n.1, p.1-13, 2000.

KAKIOMENOU, K.; TASSOU, C.; NYCHAS, G. Microbiological, physicochemical and organoleptic changes of shredded carrots stored under modified storage. International Journal of Food Science Technology, v.31, p.359366, 1996. 
KALLANDER, K.D.; HITCHINS, A.D.; LANCETTE, G.A.; SCHMIEG, J.A.; GARCIA, G.R.; SOLOMON, H.M.; SOFOS, J.N. Fate of Listeria monocytogenes in shredded cabbage stored at 5 and $25^{\circ} \mathrm{C}$ under a modified atmosphere. Journal of Food Protection, v.54, p.302-304, 1991.

KING, A.D.; MAGNUSON, J.A.; TOROK, T.; GOODMAN, N. Microflora and storage quality of partially processed lettuce. Journal of Food Science, v.56, p.459-461, 1991.

KING, J.R.; PABLO, S. Perdidas de vitaminas durante el processamiento de los alimentos. Revista Chilena de Nutricion, v.5, p.143-152, 1987.

KLEIN, B.P. Nutritional consequences of minimal processing of fruits and vegetables. Journal of Food Quality, v.10, n.3, p.179-193, 1987.

KURKI, L. Leek quality changes in CA-storage. Acta Horticulturae, v.10, p.8589, 1979.

LABUZA, T.P.; BREENE, W.M. Applications of "active packaging" for improvement of shelf-life and nutritional quality of fresh and extended shelflife foods. Journal of Food Processing and Preservation, v.13, p.1-69, 1989.

LANA, M.M.; FINGER, F.L. Atmosfera modificada e controlada: aplicação na conservação de produtos hortícolas. Brasília: EMBRAPA, 2000. p.5.

LAMIKANRA, O.; WATSON, M.A. Biochemical changes associated with freshcut fruit processing and storage. Freshness and Shelf Life of Foods, v.836, p.52-68, 2003. 
LERNER, B.R. A alimentação e a anemia carencial em adolescentes. São Paulo, 1994. 112p. Tese (Doutorado) - Faculdade de Saúde Pública, Universidade de São Paulo.

LEWIS, D.C.; SHIBAMOTO, T. Shelf-life of fruits. In: CHARALMBOUS, G. (Ed.). Handbook of food and beverage stability. Orlando: Academic Press, 1986. p.353-389.

LI, P.; BARTH, M.M. Impact of edible coatings on nutritional and physiological changes in lightly-processed carrots. Postharvest Biology and Technology, v.14, n.1, p.51-60, 1998.

LUENGO, R. de F.A.; PARMAGNANI, R.M.; PARENTE, M.R. et al. Tabela de composição nutricional de hortaliças. Brasília: EMBRAPA Hortaliças, 2000. 4p. (EMBRAPA Hortaliças. Documento, 26)

MAESTRO, V. Padrão alimentar e estado nutricional: caracterização de escolares de município paulista. Piracicaba, 2002. 116p. Dissertação (Mestrado) - Escola Superior de Agricultura "Luiz de Queiroz", Universidade de São Paulo.

MAHAN, L.K.; ARLIN, M.T. Krause: alimentos, nutrição e dietoterapia. 8.ed. São Paulo: Roca, 1995. 957p.

MAKISHIMA, N. Mapeamento da produção e consumo de hortaliças no Brasil. Brasília: EMBRAPA, 2000. 7p.

MALAVOLTA, E.; VITTI, G.C.; OLIVEIRA, S.A. de. Avaliação do estado nutricional das plantas: princípios e aplicações. Piracicaba: Associação Brasileira para Pesquisa da Potassa e do Fosfato, 1989. 201p. 
MANVELL, P.M.; ACKLAND, M.R. Rapid detection of microbial growth in vegetable salads at chill and abuse temperatures. Food Microbiology, v.3, p.59-65, 1986.

MANZANO, M.; CITTERIO, B.; MAIFRENI, M. et al. Microbial and sensory quality of vegetables for soup packaged in different atmospheres. Journal of the Science of Food Agriculture, v.67, n.4, p.521-529, 1995.

MARCHETTI, R.; CASADEI, M.A.; GUERZONI, M.E. Microbial population dynamics in ready-to-use vegetable salads. Italian Journal of Food Science, v.4, p.97-108, 1992.

MATHOOKO, F.M. Regulation of respiratory metabolism in fruits and vegetables by carbon dioxide. Postharvest Biology and Technology, v.9, p.247-264, 1996.

MAZZILLI, R.N. Contribuição e interferência da merenda escolar no dia alimentar de crianças matriculadas em centros de educação e alimentação do pré-escolar - CEAPE'S. São Paulo, 1983. 117p. Tese (Doutorado) Faculdade de Saúde Pública, Universidade de São Paulo.

MELO, B. Pequena agroindústria ganha força. O Estado de São Paulo. Suplemento Agrícola, São Paulo, 29 ago. 2001. p.G10-G11.

MESQUITA, A. Como fazer do seu sítio um pequeno negócio. Folha de São Paulo. Agrofolha, São Paulo, 20 nov. 2001. p.B12. 
MORETTI, C.L. Processamento mínimo de mandioquinha salsa e pimentão. In: ENCONTRO NACIONAL SOBRE PROCESSAMENTO MÍNIMO DE FRUTAS E HORTALIÇAS, 2., Viçosa, 2000. Palestras. Viçosa: UFV, 2000. p.132-139.

NEGUYEN-THE, C.; CARLIN, F. The microbiology of minimally processed fresh fruits and vegetables. Critical Reviews in Food Science and Nutrition, v.34, p.371-401, 1994.

NEGUYEN-THE, C.; HALNA-D.; UfRÉTAY, B.; SILVA, A.A. The microbiology of mixed salad containing raw and cooked ingredients without dressing. International Journal of Food Science and Technology, v.31, p.481-487, 1996.

O'BEIRN, D.; BALLANTYNE, A. Some effects of modified atmosphere packaging and vacuum packaging in combination with antioxidants on quality and storage life of chilled potato strips. International Journal of Food Science and Technology, v.22, p.515-523, 1987.

OHTA, H.; SUGAWARA, W. Influence of processing and storage conditions on quality stability of shredded lettuce. Journal of Food Quality, v.10, p.432438, 1987.

OLIVEIRA, J.; PHILIPPI, S.T.; CYRILLO, D.C. et al. A alimentação de escolares no município de São Paulo. In: CONGRESSO BRASILEIRO DE CIÊNCIA E TECNOLOGIA DE ALIMENTOS, 16., Rio de Janeiro, 1998. Anais. Rio de Janeiro: SBCTA, 1998. p.495-498. 
OMATI, C.; GODOY, R. O mercado de embalagens de atmosfera modificada. Alimentos \& Tecnologia, v.11, n.66, p.17-16, 1996.

PARK, D.L.; RUA, S.M.; ACKER, R.F. Application of a new hypochlorite sanitizer for reducing bacterial contamination on foods. Journal of Food Protection, v.54, p.960-965, 1991.

PERDUE, R.R. MAP: shoppers wooed with fresh ideas. Canadian Packaging, v.42, p.26-28, 1989.

PIAGENTINI, A.M.; GÜEMES, D.R.; PIROVANI, M.E. Efecto del tratamento químico y tipo de envase sobre la calidad sensorial de espinaca mínimamente procesada. Higiene Alimentar, v.14, n.74, p.32-36, 2000.

PIARD, J.C.; DESMAZEAUD, M. Inhibiting factors produced by lactic acid bacteria. 2. Bacteriocins and other antimicrobial substances. Le Lait, v.72, p.113-142, 1992.

PIGA, A.; DEL CARO, A.; PINNA, I.; AGABBIO, M. Changes in ascorbic acid, polyphenol content and antioxidant activity in minimally processed cactus pear fruits. Lebensmittel-wissenschaft UND-Technologie-Food Science and Technology, v.36, n.2, p.257-262, 2003.

PINHEIRO-SANT'ANA, H.M.; STRINGHETA, P.C.; BRANDÃO, S.C.C.; DRACZ, S.; AZEREDO, E.M.C. Estabilidade de carotenóides e valor de vitamina A em cenoura (Daucus carota L.) preparada em pequenas quantidades. In: CONGRESSO BRASILEIRO DE CIÊNCIA E TECNOLOGIA DE ALIMENTOS, 15., Poços de Caldas, 1996. Resumos. Viçosa: UFV, 1996. p.260. 
POSTE, L.M.; MACKIE, D.A.; BUTLER, G. et al. Laboratory methods for sensory analysis of food. Ottawa: Research Branch Agriculture Canada Publication, 1991. 90p.

PRADO, M.E.T.; VILAS BOAS, E.V. de B.; SANTOS, J.C.B. et al. Influência do hipoclorito de sódio sobre a qualidade de abacaxis minimamente processados. In: ENCONTRO NACIONAL SOBRE PROCESSAMENTO MÍNIMO DE FRUTAS E HORTALIÇAS, 2., Viçosa, 2000. Resumos. Viçosa: UFV, 2000. p.5.

PREGNOLATTO, W.; PREGNOLATTO, N.P. Normas analíticas do Instituto Adolfo Lutz: métodos químicos e físicos para análise de alimentos. 3.ed. São Paulo: Instituto Adolfo Lutz, 1985. v.1. 533p.

PRIEPKE, P.E.; WEI, L.S.; NELSON, A.I. Refrigerated storage of prepackaged salad vegetables. Journal of Food Science, v.41, p.379-382, 1976.

RABELLO, T. Processamento mínimo, lucro máximo. Frutas e Legumes, v.1, n.1, p.13-20, 1999.

RAYDON, B.P. Fatores econômicos que conduzem a perdas de alimentos. In: AMAYA-FARFAN, J.; FARIA, J.A.F.; SALAY, E. Encontro municipal sobre o desperdício de alimentos. Campinas: Unicamp, 1993. p.30-37.

REYES, V.G. Improved preservation system for minimally processed vegetables. Food Australia, v.48, p.87-90, 1996.

ROBBS, P.G.; BARTZ, J.A.; McFIE, G. et al. Causes of decay of fresh-cut celery. Journal of Food Science, v.61, n.2, p.444-455, 1996. 
ROCOURT, J.; BENEMBAREK, P.; TOYOFUKU, H.; SCHLUNDT, J. Quantitative risk assessment of Listeria monocytogenes in ready-to-eat foods: the FAO/WHO approach. Fems Immunology and Medical Microbiology, v.35, n.3, p.263-267, 2003.

RODRIGUEZ-AMAYA.; RAYMUNDO, L.C.; LEE, T.C.; SIMPSON, K.L.; CHICHSTER, C.O. Carotenoids pigments changes in ripenning Momordica charantia fruits. Annals of Botany, v.40, p.615-624, 1976.

ROSA, O.O. Microbiota associada a produtos hortícolas minimamente processados comercializados em supermercados. Lavras, 2002. 120p. Tese (Doutorado) - Universidade Federal de Lavras.

SAGOO, S.K.; LITTLE, C.L.; WARD, L.; GILLESPIE, I.A.; MITCHELL, R.T. Microbiological study of ready-to-eat salad vegetables from retail establishments uncovers a national outbreak of salmonellosis. Journal of Food Protection, v.66, n.3, p.403-409, 2003.

SALTVEIT, M.E. Is it possible to find and optimal controlled atmosphere ? Postharvest Biology and Technology, v.27, n.1, p.3-13, 2003.

SANCHES, M. Hortaliças: consumo e preferência de escolares. Piracicaba, 2002. 143p. Dissertação (Mestrado) - Escola Superior de Agricultura "Luiz de Queiroz", Universidade de São Paulo.

SARANTÓPOULOS, C.I.G.L.; OLIVEIRA, L.M.; CANAVESI, E. Frutas e hortaliças minimamente processadas. In: Requisitos de conservação de alimentos em embalagens flexíveis. Campinas: CETEA, ITAL, 2001. cap.18, p.187-195. 
SARRUGE, J.R.; HAAG, H.P. Análises químicas em plantas. Piracicaba: ESALQ, 1974.56p.

SCOTT, V.N. Interaction of factors to control microbial spoilage of refrigerated foods. Journal of Food Protection, v.52, n.6, p.431-435, 1989.

SENESI, E.; PRINZIVALLI, C.; SALA, M. et al. Physicochemical and microbiological changes in fresh-cut green bell peppers as affected by packaging and storage. Italian Journal of Food Science, v.12, n.1, p.5564, 2000.

SGARBIERI, V.C. Alimentação e nutrição. Campinas: Ed. Unicamp, 1987. 387p.

SILVA, M.E.M.P. Teores de vitamina $\mathrm{C}$ em alimentos de consumo habitual na região de São Paulo. São Paulo, 1990. 103p. Dissertação (Mestrado) Faculdade de Ciências Farmacêuticas, Universidade de São Paulo.

SILVA, M.V. da. Estado nutricional de escolares matriculados em centros integrados de educação pública - CIEP'S. São Paulo, 1996. 103p. Tese (Doutorado) - Faculdade de Saúde Pública, Universidade de São Paulo.

SILVA, N. da.; JUNQUEIRA, V.C.A.; SILVEIRA, N.F.A. Manual de métodos de análise microbiológica de alimentos. São Paulo: Livraria Varela, 1997. 295p.

SOLIVA-FORTUNY, R.C.; LLUCH, M.A.; QUILES, A.; GRIGELMO-MIGUEL, N.; MARTIN-BELLOSO, O. Evaluation of textural properties and microstructure during storage of minimally processed apples. Journal of Food Science, v.68, n.1, p.312-317, 2003. 
TASSINARI, A.; FRANCO, B.D.G.; LANDGRAF, M. Incidence of Yersinia spp. in food in São Paulo, Brazil. International Journal of Food Microbiology, v.21, p.263-270, 1994.

TATSUMI, Y.; WATADA, A.E.; WERGIN, W. P. Scanning electron microscopy of carrot stick surface to determine cause of white translucent appearance. Journal of Food Science, v.56, p.1357-1359, 1991.

TATSUMI, Y.; WATADA, A.E.; LING, P. P. Sodium chlorine treatment or waterjet slicing effects on white tissue development os carrot sticks. Journal of Food Science, v.58, n.6, p.1390-1392, 1993.

TEIXEIRA, G.H. de A.; DURIGAN, J.F.; MATTIUZ, B. et al. Processamento mínimo de mamão formosa. Ciência e Tecnologia de Alimentos, v.21, n.1, p.47-50, 2001.

TELES, C.S.; RAMOS, A.M.; PUSCHMANN, R. et al. Embalagens plásticas para conservação de couve minimamente processada sob atmosfera modificada ativa. In: ENCONTRO NACIONAL SOBRE PROCESSAMENTO MÍNIMO DE FRUTAS E HORTALIÇAS, 2., Viçosa, 2000. Resumos. Viçosa: UFV, 2000. p.39.

TUNCAN, E.U. Effect of cold temperature on germicidal efficacy of quaternary ammonium compound, iodophor and chlorine on Listeria. Journal of Food Protection, v.56, p.1029-1033, 1993.

UNIVERSIDADE DE SÃO PAULO - USP. Tabela brasileira de composição de alimentos. http://www.fcf.usp.br/tabela/tbcamenu.php. (15 nov. 2001) 
VALERO, M.; HERNÁNDEZ-HERRERO, L.A.; FERNÁNDEZ, P.S. et al. Characterization of Bacillus cereus isolates from fresh vegetables and refrigerated minimally processed foods by biochemical and physiological tests. Food Microbiology, v.19, p.491-499, 2002.

VANDERZANT, C.; SPLITTSTOESSER, D.F. Compendium of methods for the microbiological examination of foods. Washington: American Public Health Association, 1992. 1219p.

VASCONCELOS, A.R.D. Utilização do cloreto de cálcio e atmosfera modificada na conservação de caqui cv. Fuyu. Lavras, 2000. 85p. Tese (M.S.) Universidade Federal de Lavras.

VELANI, S.; ROBERTS, D. Listeria monocytogenes and other Listeria spp. in prepacked mixed salads and individual salad ingredients. PHLS Microbiology Digest, v.8, p.21-22, 1991.

WANG, C.Y. Postharvest responses of chinese cabbage to high $\mathrm{CO}_{2}$ treatment or low $\mathrm{O}_{2}$ storage. Journal of the American Society for Horticultural Science, v.108, p.125-129, 1983.

WATADA, A.E.; ABE, K.; YAMAUCHI, N. Physilogical activities of partially processed fruits and vegetables. Food Technology, v.44, n.5, p.116-122, 1990.

WILEY, R.C. (Ed.). Minimally processed refrigerated fruits \& vegetables. New York: Chapman \& Hall, 1994. 368p. 
WILSON, D. Nutrition status of children, inmates of a small instituition of homeless children, in the capital of the state of São Paulo, Brazil. Revista de Saúde Pública, v.14, n.2, p.300-309, 1980.

ZAGORY, D.; KADER, A.A. Modified atmosphere packaging of fresh produce. Food Technology, v.42, n.9, p.70-77, 1988.

ZAGORY, D.; KADER, A.A. Quality maintenance in fresh fruits and vegetables by controlled atmospheres. In: JEN, J.J. (Ed.). Quality factores of fruits and vegetables. Washington: American Chemical Society, 1989. cap.4, p.174-187. (ACS Symposium Series, 405)

ZANGH, S.; FARBER, J.M. The effects of various disinfectants against Listeria monocytogenes on fresh-cut vegetables. Food Microbiology, v.13, p.311$321,1996$.

ZHUANG, R.Y.; BEUCHAT, LR.; ANGULO, F.J. Fate of Salmonella montevideo on and in raw tomatoes as affected by temperature and treatment with chlorine. Applied and Environmental Microbiology, v.61, p.2127-2131, 1995.

ZONTA, E.P.; MACHADO, A.M.; SILVEIRA JUNIOR, P. SANEST: sistema de análise estatística para microcomputadores. Pelotas: Universitária, 1986. 92p. 


\section{APÊNDICE}


Obrigada por participar da nossa pesquisa!!!

Nome:

Data

Assinale, por favor, qual desses dois tipos de embalagem para cenoura (pimentão/salada mista) minimamente processada você compraria?

Vácuo

Atmosfera modificada

Por qual razão escolheu esta alternativa? 
Nome

Data

Muito obrigado por participar de nossa pesquisa com cenoura minimamente processada. Você receberá três amostras deste poduto para avaliar. Por favor, leia este questionário antes de iniciar o teste, depois prove o produto e responda as questões que se seguem:

1- Indique o quanto você gostou da cor do produto:

( ) gostei extremamente

( ) gostei muito

( ) gostei moderadamente

( ) gostei ligeiramente

( ) não gostei nem desgostei

( ) desgostei ligeiramente

( ) desgostei moderadamente

( ) desgostei muito

( ) desgostei extremamente

2- Indique o quanto você gostou do aroma do produto:

$\ldots$

3- Indique o quanto você gostou do sabor do produto:

...

4- Indique o quanto você gostou da textura do produto:

...

5- Indique o quanto você gostou de maneira geral do produto:

$\cdots$

6- Comentários: por favor, indique o que em particular você mais gostou ou menos gostou neste produto (use palavras ou frases):

Mais gostei: Menos gostei:

7- Qual a sua faixa de idade?
( ) 18 a 25 anos
) 25 a 35 anos
) acima de 35 anos 
Nome

Data

Muito obrigado por participar de nossa pesquisa com pimentão minimamente processado. Você receberá quatro amostras deste produto para avaliar. Por favor, leia este questionário antes de iniciar o teste, depois prove o produto e responda as questões que se seguem:

1- Indique o quanto você gostou da cor do produto:

( ) gostei extremamente

( ) gostei muito

( ) gostei moderadamente

( ) gostei ligeiramente

( ) não gostei nem desgostei

( ) desgostei ligeiramente

( ) desgostei moderadamente

( ) desgostei muito

( ) desgostei extremamente

2- Indique o quanto você gostou do aroma do produto:

$\ldots$

3- Indique o quanto você gostou do sabor do produto:

...

4- Indique o quanto você gostou da textura do produto:

...

5- Indique o quanto você gostou de maneira geral do produto:

$\cdots$

6- Comentários: por favor, indique o que em particular você mais gostou ou menos gostou neste produto (use palavras ou frases):

Mais gostei:

Menos gostei:

7- Qual a sua faixa de idade?

( ) 18 a 25 anos ( ) 25 a 35 anos ( ) acima de 35 anos 
Nome

Data

Você está recebendo três amostras cruas de salada mista (vagem e batata) minimamente processada. Por favor, observe 0 produto e responda a questão abaixo:

Indique o quanto você gostou da cor do produto:

( ) gostei extremamente

( ) gostei muito

( ) gostei moderadamente

( ) gostei ligeiramente

( ) não gostei nem desgostei

( ) desgostei ligeiramente

( ) desgostei moderadamente

( ) desgostei muito

( ) desgostei extremamente

Por qual razão escolheu esta alternativa? 
Nome

Data

Você está recebendo três amostras cozidas de salada mista (vagem e batata) minimamente processada. Por favor prove o produto e responda as questões que se seguem:

1- Indique o quanto você gostou do aroma do produto:

( ) gostei extremamente

( ) gostei muito

( ) gostei moderadamente

( ) gostei ligeiramente

( ) não gostei nem desgostei

( ) desgostei ligeiramente

( ) desgostei moderadamente

( ) desgostei muito

( ) desgostei extremamente

2- Indique o quanto você gostou do sabor do produto:

...

3- Indique o quanto você gostou da textura do produto:

...

4- Indique o quanto você gostou de maneira geral do produto:

5- Comentários: por favor, indique o que em particular você mais gostou ou menos gostou neste produto (use palavras ou frases):

Mais gostei:

Menos gostei:

6- Qual a sua faixa de idade?
( ) 18 a 25 anos
( ) 25 a 35 anos
( ) acima de 35 anos 